\title{
The Black Dervish of Armenian Futurism
}

\section{Citation}

Russell, James R. Forthcoming. "The Black Dervish of Armenian Futurism." Journal of Armenian Studies.

\section{Permanent link}

http://nrs.harvard.edu/urn-3:HUL.InstRepos:12172183

\section{Terms of Use}

This article was downloaded from Harvard University's DASH repository, and is made available under the terms and conditions applicable to Open Access Policy Articles, as set forth at http:// nrs.harvard.edu/urn-3:HUL.InstRepos:dash.current.terms-of-use\#OAP

\section{Share Your Story}

The Harvard community has made this article openly available.

Please share how this access benefits you. Submit a story.

Accessibility 


\title{
The Black Dervish of Armenian Futurism.
}

\author{
By James R. Russell, \\ Harvard University.
}

There is an Armenian saying that one must turn a library inside out to write a single book. One might adapt an English adage, too, to this just reflection on the process of scholarship: No work of research is an island. (And there is no library worth turning inside out without a librarian to help.) I was not aware of the work of the poet studied here till Michael Grossman, the cataloguer of Georgian and Armenian books, showed me a reprint of the volume dedicated to Sofia Mel'nikova with the poems of Kara Darviš in it. Shortly thereafter, Marc Mamigonian of the National Association for Armenian Studies and Research unearthed copies of the poet's manifesto and two novels that had been bound with other pamphlets of the era in hardcover miscellanies donated to the NAASR library in Belmont, MA. ${ }^{1}$ And another friend mentioned Krikor Beledian's superb work on the Armenian Futurists to me around the same time. It has proven very useful in this study, though my approach and method are quite different.

I had the pleasure to present the first fruits of my work on Kara Darviš as a lecture to the Armenian Studies program at California State University, Fresno, on 20 March 2014, by invitation of its directors, Profs. Barlow Der Mugrdechian and Sergio La Porta. I am grateful to them from for their wonderful and stimulating company, and to my host in Fresno, Larry Balakian, whose hospitality is as warm as the sun of the Central Valley in spring, and as abundant as its oranges and grapes. Armenian culture and life thrive in Fresno as in few other places left on the planet;

\footnotetext{
1 Two novels and a manifesto of Kara Darviš were found in two different hardbound miscellanies of pamphlets and soft-cover Armenian publications, from the collection of Harry and Araxie Kolligian, donated to NAASR in 2001. I list the contents of each, as they may afford a glimpse into the reading habits of educated American Armenians in the mid-20 $0^{\text {th }}$ century. Contents of the first volume: 1. Hatantir ant'erc'uack' azgayin ew òtar matenagirnerē k'ałuac antaneac' ew dproc'ac' hamar ("Select readings excerpted from national [i.e., Armenian] and foreign writers, for families and schools"), author given as Mšak ("Cultivator"), Constantinople: Aramean tpagrut'iwn [Aramean printers], 1880; 2. E(łia) Tēmirčipašean (Yeghia Demirjibashian), Nor keank', A: Azgayin lezu [“New Life, Part 1: The National Language"], A.M. Aščean ew anker. [A.M. Ashjian \& Co.], 1879; 3. Kara-Darwiš, Inč è Fut'urizmə? ["What is Futurism?"], T'ifliz, Tparan "Ēpōxa”, Muzeyski perēul. No. 3 [Tiflis, "Epoch" publishers, Museum lane no. 3], 1914, with the stamp of the Zardarean gratun ["Librairie Zartarian"], Tchakmakdjilar, Constantinople (see plate appended to this study); 4. Kara-Darwiš, Keank'i jut'aka ["The Violin of Life"], Tp. "Slōvō", Gimnazič 'eskayea, No. 1, T'ifliz ["The Word" publishers, Gymnasium St., no. 1, Tiflis], 1917; 5. St. Tēr-Awetik'ean, Patmuack'ner ["Stories"], Kovkasi Hayoc' Hratarakč'akan Bnkerut'iwn [Publication Society of the Armenians of the Caucasus], No. 6, Tiflis, Tparan "Hermēs" ["Hermes" publishers], 1912. Contents of the second volume: 1. E. Vōynič', Boŕ, vēp eresnakan t'weri italakan yełap'oxut'ean ōreric', t'rgm. Lewon Šant', Anglierēn bnagira araj̆in angam tpwac è 1897 t'win Londonum, T'iflis, Ēlek'trašarž tparan "Hermēs" anker., Madat'ean p'ołoc'15, 1906 [“Bor, a novel from the days of the Italian revolution of the [18]30s; the original English text was first published in London, 1897," Tiflis, Hermes Co. electric press, 15 Madatian St., 1906]; 2. Kara-Darwiš, Erwand Gōš, T'iflis 1911, Tparan Šapsōni [Shapson Press]. The back cover of the latter advertises literary works translated from Russian to Armenian by Akop Gendzhian and available for sale.
} 
and one works under the spell of the creative labors of friends met and made in Fresno: Aris Janigian's super-contemporary novel This Angelic Land, which explores every facet of being Armenian in America's agonizing and multifaceted jewel, Los Angeles, and Jim Karagozian's elegant, delicate artistry on the classical kanun. I love you guys.

Samuel Taylor Coleridge wrote, as we can tell from his manuscript, a complete and fully formed poem called Kubla Khan. But he claimed in his published prologue that the poem, which he was capturing on paper from the fast fading memory of a dream vision, was interrupted in the course of his work on it and was to have been much longer. The unexpected visit of a tradesman from the nearby town of Porlock interrupted the magic and the poet forgot the rest of what he had intended to describe. The man from Porlock has become a metaphorical figure, the coitus interruptus of the creative process; Stevie Smith has a poem that wonders playfully about him. Perhaps Coleridge was inducing the reader herself to feel the keen delicacy of a vanishing reverie, the poignancy of its loss. Armenian culture has endured millennially in spite of loss: the fall and desolation of the city of Ani, the collapse of the Cilician kingdom. But the suddenness of $20^{\text {th }}$ century catastrophes is the dire man from Porlock for real. These calamities leave one with the sense, not only of the loss of monuments of culture brought to completion and perfection, but of interruption - of creation cut off in the midst of the act, leaving one to wonder what the ripened fruit of the endeavor might have been. On the eve of the First World War, Daniel Varuzhan and his associates on the board of the magazine Mehean intended to re-infuse their language with the abundant lexical material and idiom of the numerous Armenian dialects of the native Anatolian highlands that had been obscured by the strictly controlled rules and lexicon of Classical Armenian (grabar) on the one hand and the normative, standardized literary Western Armenian of the urban centers (ašxarhabar) on the other. (There was also, of course, equally standardized and canonized Eastern Armenian ašxarhabar of the Russian Empire.) So, had mass murder not intervened, we might today have a Third Armenian, an unknown, rich, flexible tongue for a people still standing on a verdant earth. ${ }^{2}$ Perhaps Indra's novel Nerašxarh ("The Inner World") was the first and only book in this Third Armenian, a tongue worthy of the dream of Kubla Khan.

The vibrant literary culture of Armenian Constantinople in the late Ottoman period ended suddenly with the murders of its young poets at the outset of the general slaughter of 1915. What might have come from the pens of Varuzhan, Siamant'o, Sevag, Indra, had they lived on, to be old men? What music might have reach our ears, had the composer Komitas not been driven mad by the horrors he saw? The Stalinist purges of 1937 swept away Charents, Aksel Bakunts, Zabel Esayan, and hundreds of others: what if they had lived? Socialist Realism imposed a deadening puritanism on the arts: what if culture in Erevan had been allowed to

2 See the excellent new study by Marc Nichanian, Mourning Philology: Art and Religion at the Margins of the Ottoman Empire, New York, Fordham University Press, 2014, pp. 124-127. To which the American labor organizers might have replied with their intrepid slogan, "Don't mourn, organize." 
develop in conditions of liberty? As the centenary of the 1915 Genocide approaches, it seems as much a moral duty as well as a worthwhile scholarly task to offer to the English reader some of the treasures finished before the man from Porlock darkened the door and interrupted the dream. Just as Armenian culture was becoming avant-garde, Futurist, countercultural, it was lost, and most of its contribution to the progress of the free arts and letters of humanity was forgotten. Nobody has the right to forget, any more than to deny.

May I offer the present work to my learned colleague and dear friend and collaborator on numerous Armenian bibliophilic projects, Michael Grossman, in the hope of many more years working and breaking bread together. May it find favor with him, and with you. Three apples fell from heaven...

This is not the first introduction in English to the Armenian poet who styled himself Kara Darviš, the Black Dervish, but it is the longest; and it offers texts, both by the poet and of supplementary interest, that have not been translated hitherto but are of some importance to the history of the Futurist movement. This material augments our understanding of modern Armenian literature, and situates it in the context of both world culture and the artistic scene of the early $20^{\text {th }}$ century in the last years of the Russian ancien régime and the early history of the Soviet Union. Our poet lived and worked in the Georgian capital, Tiflis, during the tumultuous years of the First World War and the Russian Revolution - roughly two decades in all, from 1910 to 1930. These events destroyed and transformed much of the world, and had a particularly devastating impact upon Armenians. He lived, though, not only in that historical maelstrom but also at what he and his friends believed was the dawn of a new culture. He was more than a time traveler; he was a denizen of the times to come.

For Kara Darviš was a Futurist, excavating the foundations of his native tongue, the Armenian language, with the aim of creating new sounds and visual patterns for a poetic language and method of graphic art of that a different kind of man, freer, healthier, honest, unconstrained by tradition, was to speak, write, and paint tomorrow. The Futurists in their new literature experimented with the shape of words, the look and size of typefaces and the direction and orientation of texts, their words bursting off the line, running up and down the page, dashing in circles, leaping skywards. Their paintings and sculptures sought to depict the stages of motion, not still lives; so the metal statue of a man scalloped the successive movements of his muscles over time, and the same part of a horse repeated itself in freeze frames across the canvas, embracing its gallop. Their aim was not so much to change what we see and hear but to release the senses from the stereotypes of conventional art and literature in order better to express and depict what is really there- and what is there right now, too. Not a classical landscape standing stock still, but a city of clean-lined skyscrapers and streamlined stations and airports teeming with cars, factories, airplanes. Words are not monotonous, linear 
phenomena crawling in straight lines across a page. There are different sounds all around and above and below us, with different accents and pitches. The operations of the mind are not limited to the limited scope of conscious awareness, but embrace also the irrational and the subconscious. So why not write in different directions, with letters of different sizes, using not just the words that are part of everyday speech, but nonsense words, or magic spells - the sounds of dreams, of childhood, of nature, of machines? Airplanes were taking men into the sky and radios were conveying speech invisibly across great distances at speed: why should art and literature crawl slowly on the ground? ${ }^{3}$

Kara Darviš was born Hakob Genjian in the north Caucasus, in the twilight decades of the Russian Empire. Like many Armenians in the Empire, he was deeply connected to Russian culture and the Russian language, which he spoke with native fluency, peppering his Armenian prose very liberally with Russian words that would have been utterly incomprehensible to an Armenian living not all that far away, in Ottoman Turkey. (In this he was no different from other educated Armenians in Russia; and Western Armenian writers, to a greater or lesser degree, flavored their work with Turkish, Persian, and Arabic words.) He was married to a Russian woman, and most of his fellow Futurists at the various cafés he frequented in Tiflis were Russians. But he moved in Armenian circles just as intensely- he worked as a correspondent for several Armenian papers, and mixed with the Armenian literati, befriending the novelist Kostan Zarian and the young revolutionary poet Yeghishe Charents. In the company of nonconformist artists, he still stood out as an original, true to his cognomen of dervish. He was an eccentric who dressed oddly, behaved scandalously, detested economic inequality, liked a drink, and believed in the centrality of eroticism to life, in free love. He was proud of his nation and its ancient culture; but this feeling was not shaded by the racialist and chauvinist bigotry of writers like Zarian. He proclaimed himself the brother of all men and a citizen of the world, a cosmopolitan. His poetic manifestoes echo Walt Whitman and William Blake; and they foreshadow the American Beat poet Allen Ginsberg.

Kara Darviš is noteworthy for the wider field of Futurism for occupying a particular place in it. There were several Armenian Futurists; but the others simply joined a larger movement whose center was in Europe. Kara Darviš was consciously a man of the (Near)East who appreciated the language and culture of the streets of Tiflis and Baku, and addressed his criticisms of conservatism and repression not only to mainstream culture in general but to the particular tendency of Armenians, Iranians, and others to denigrate their own culture and to imitate everything western. That imitation, often slavish and superficial, led more often to alienation from oneself than to authentic partnership with the rest of world culture; and it reaffirmed imperial politics by deifying the ways of colonial rulers. By focusing on this inferiority complex as a cultural phenomenon, and calling on Armenians and

${ }^{3}$ One of the best surveys of the art of the movement remains the monograph and exhibition catalogue by Joshua C. Taylor, Futurism, Museum of Modern Art, New York, distributed by Doubleday, New York, 1962. 
their neighbors to respect and value their own everyday culture, and, thereby, themselves as human beings worthy of full social and political equality with all other men, he anticipated later studies of what has come to be called Orientalism. He, and his friend Charents in the decade following his eclipse, were indeed the heralds of an authentic and authentically Armenian counterculture.

Until the early decades of the 20 $0^{\text {th }}$ century, Armenians were, and had been for centuries, a stateless people. As a Christian minority in the Muslim world they were barred from the traditional social positions that secured power: land ownership, the military, and government. In the coastal cities of Turkey in particular, they gained wealth and prominence through trade, industry, and communication - all of these skills demanding a cosmopolitan outlook and receptivity to progress and change. The Armenians living in the interior of Anatolia likewise developed modern schools and businesses in the cities, but villagers and farmers labored under oppressive conditions, paying tribute to Ottoman officials and Kurdish tribal gangs. In the Russian Empire the position of the Armenians was considerably more secure; and after Russia's liberation of Erevan in 1828 many thousands of Armenians emigrated from Turkey and Iran to rebuild their lives under the protection of the Christian tsar. But they were still not members of the dominant nationality, whose official policy was Russification, and the Armenian Church was not recognized as Orthodox - so to a great extent the same cosmopolitan model of world view, economic activity, and urban development applied. This is perhaps one reason why Armenians did innovative things common in the west but unknown in the east. An eccentric Armenian of Smyrna named Bedros Tenger, not a Turk, Arab, or Persian, strove to transcend the boundaries of ethnicity and religion, laboring in hope for a new world where those limitations might no longer cripple human endeavor, and invented the only artificial language ever to come out of the Near East whose express purpose was to promote universal human solidarity. The West, by contrast, produced about 500 of them in the $19^{\text {th }}$ and $20^{\text {th }}$ centuries, though only Esperanto has endured. ${ }^{4}$ And another Armenian, the subject of our present study, invented a specifically Near Eastern Futurism.

But it is indicative of the very precariousness of the situation of the Armenian people that neither Seh-lerai - the Armenian "Esperanto" - nor the Futurist language and poetry of Kara Darviš, found receptivity in the lands of their birth and survived. Far from surviving, neither is even remembered by any but a very few specialists. In the wake of the 1915 Genocide, the formation of the Soviet Union in 1922, and the imposition of the deadening official dogma of Socialist Realism about a decade later under Stalinism - as we have noted above-Armenians were made subject to restraints beyond their control and were necessarily preoccupied with vital concerns of survival in the here and now, rather than an imagined tomorrow. Still a minority culture in the USSR, and entirely a diaspora culture outside the latter, Armenians clung to their ancient foundations as limpets do to a rock battered by the breakers of a stormy sea. These were anything but avant-garde or

\footnotetext{
${ }^{4}$ See J.R. Russell, “The Seh-lerai Language," Journal of Armenian Studies 10.1-2 (2012-2013), pp. 1-85.
} 
countercultural: an established church upholding accepted morals, and a canonical literature of traditional forms, underscoring these. Those were the very institutions and forms Kara Darviš found intolerably stifling and hoped to demolish. It would seem he had labored in vain. But this is not entirely so. Kara Darviš and his comrades had still contributed vitally to a humanistic and revolutionary Futurism, and its kindred movements, the streams nourished by it-Cubism, Surrealism, Dada, and the rest- did not disappear. They gained strength wherever life allowed, and became a vital motive force in the growth of the movements that spearheaded cultural, philosophical, even scientific change in the $20^{\text {th }}$ century, that championed human rights, diversity, and liberation in all its forms, and thereby created much of the future, the future in which we live now. Kara Darviš is a part of that countercultural inheritance, the blessed dissident, eccentric force of the $20^{\text {th }}$ century. Remembering him, one resists the genocidal tide of oblivion. Translating him, one re-inscribes his work in the annals of world culture: the dervish is no longer alone.

But for literary scholarship, which requires that one probe the sources of a work as part of understanding its meaning, even a movement with the name Futurism still must have a discoverable past. It begins, I think, with another war, another revolution, another young, rebellious, eccentric genius, in another country. This other poet, a very young man, first sounded articulately the themes of changed consciousness and depiction of reality, the transformation of language, universalism, the magic of words. Like Voltaire, like the citizens-in-the-making storming of the Bastille, like the band of black and white artists playing the Marseillaise in Monsieur Rick's nightclub, he was French.

In 1911-1914, the Nouvelle Revue Française published the letters of the poet Arthur Rimbaud (1854-1891). Rimbaud sought to transform the physical world through his poems, which he began writing in earnest at seventeen, and gave up writing at the age of twenty-one when he thought he had not. But ironically he created more than he could possibly imagine, since consciousness and thought are what lead us to change the world around us in fact. So he transformed the world more profoundly than any alchemical operation might essay to do. He made modern poetry. His visions transformed all the arts, and Futurism, Surrealism, and the cultural movements of the Beats and their successors - everything from Picasso to punk rock, not to mention Zdanevich, Larionov, Kamensky, Goncharova, Mayakovsky, Robakidze, Kara Darviš, and Charents - can in a way be traced to him. He came to the French capital, to scandalize its literary circles and to piss on its pedestrians from a great height, in the wake of the Franco-Prussian War and the fall of the revolutionary Paris Commune. His Lettre de voyant ("Letter of a seer"), dated 15 May 1871, is his most famous, a kind of manifesto and guide: ${ }^{5}$

\footnotetext{
${ }^{5}$ From the translation in Marcel Jean, ed., The Autobiography of Surrealism, in the series Documents of

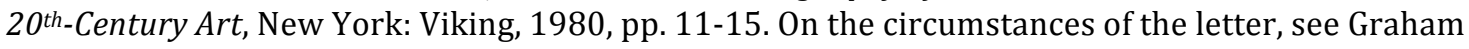
Robb's acerbic, funny, learned biography, Rimbaud, Norton: New York, 2000, pp. 85-88.
} 
"I say that one must be a seer, make oneself a seer.

The poet becomes a seer through a long, immense, and reasoned derangement of all the senses. All shapes of love, suffering, madness. He searches himself, he exhausts all poisons in himself, to keep only the quintessences. Ineffable torture where he needs all his faith, all his superhuman strength, where he becomes among all men the great patient, the great criminal, the great accursed one- and the supreme Scholar! For he reaches the unknown! Since he cultivated his soul, rich already, more than anyone else! He reaches the unknown, and when, demented, he would end by losing the intelligence of his visions, he has seen them! Let him die in his leaps among unheard-of and unnamable things; other horrible workers will come: they will begin from the horizons where the other one has collapsed!

... So the poet is actually a thief of fire. ${ }^{6}$

He is responsible for humanity, even for animals. He must see to it that his inventions can be smelled, felt, heard. If what he brings back from yonder has shape, he gives shape; is it is shapeless, he gives shapelessness. To find a language. Moreover, speech being thought, the time for a universal language will come! Only an academician, deader than a fossil, could complete a dictionary, in any tongue; weak people, who might begin to think about the first letter of the alphabet, and would soon jump into madness!

This language will be soul for the soul, summing up everything, perfumes, sounds, colors; thought hooking thought and pulling. The poet would define the amount of unknown awakening in his time in universal thought; he would give more than the formula of his thought, than the measurements of his march toward Progress! An enormity becoming a norm, absorbed by everyone, he would truly be a multiplier of Progress!

This future will be materialistic, as you see. Always filled with Number and Harmony, these poems will be made to stay. Basically, it would still be Greek poetry somehow.

Eternal art would have its functions, in the same manner as poets who are also citizens. Poetry will no longer give rhythm to action; it will be in front...

Meanwhile, let us ask novelty from the poet-ideas and shapes."

The challenge to innovation, derangement of the senses, love, progress, a new art, and a completely new kind of language, had been flung down. Among those who were to answer the call was Hakob Genjean (Genjian). He was born at Stavropol

${ }^{6}$ That is, he is Prometheus, who rebelled against the hegemony of the other Olympian gods by giving fire to man and then suffering unending torture for it (on a mountaintop, as it happens, in the Caucasus). 
in the north Caucasus in 1872, duly entered the Armenian seminary at Nor Naxiǰewan (Nakhichevan) - Rostov-on-the-Don - but left in 1893 without taking holy orders. Then he taught at the Geworgean college in Ëjmiacin (Echmiadzin, the holy see of the Armenian Church, near Erevan) in 1906-1907, and wrote poems of a neo-pagan, decadent, mildly erotic, mildly Symbolist sort. He adopted the pen name Kara Darviš ${ }^{7}$ with the publication of his short story Leran astuacuhin, "The goddess

${ }^{7}$ Kara is Turkish for "black". In compound expressions it is often a term of endearment; kara oğlan (or Arm. manuk) "black boy" has the implication of beauty, even valor. The New Persian word darvǐs means, literally, a poor man. It derives ultimately from the Avesta: dragu- (later Middle Iranian driyōs, from which the modern Persian form comes) was the designation of a follower of the Prophet Zarathuštra, who saw himself as in need of the gift (magu-) of the revelation of Ahura Mazdā, the Lord Wisdom. From this first insight, which did not imply material destitution, only the consciousness of spiritual need, came the ritualized practice in Iranian Islam of a material asceticism by mystics who were itinerant loners wandering about draped in scarves, with a begging bowl and an ax for cutting wood. Dervishes also joined fraternal orders, employing techniques of ecstatic prayer, music, and dance to seek God through love (Arabic 'išq, hence 'ašūq, "lover", Arm. ashugh, a wandering minstrel). The Arabic translation of darvišs, faqīr "poor man", is another designation of the Sufi. Faqri fakhrī, "My poverty is my pride" is a slogan attributed to Mohammed. A balance, even a symbiosis, gradually obtained between Sufism and the communal structure of normative Islam with its strict laws and morals; but for the eccentric or the free spirit suffocating in society, the way of the dervish was an escape hatch. At the turn of the century the image of the dervish was, understandably, popular with Armenian writers, including some more conformist than Hakob Genjian. Even the thoroughly mainstream Western Armenian writer, scholar, educator, and communal leader Aršak Č'ōpanean (Chobanian)(1872-1954) used the pen name Dērwiš on occasion. Another writer, considerably obscurer, styled himself Devrish (with metathesis of the consonantal cluster); and the cover of one of his books is illustrated here to afford an idea of the image of the dervish in Armenian. I summarize and annotate this communication of Marc Mamigonian, NAASR, Belmont, MA, 24 March 2014, about him: Krikor Arakel Keljik (1883-1963) published poems and novels under the name "Devrish" (author's spelling; Arm. Tēvriš). Like his elder brother Bedros Arakel Keljik, Krikor was a writer and activist, an Oriental rug merchant and a founder of the Twin Cities (i.e., Minneapolis and St. Paul, MN) Armenian community. They contrasted, however, in their political and literary leanings: Bedros, a former Hnč'ak (Arm. "Bell”, after Alexander Herzen's Russian Kolokol: a progressive democratic party), was a local-color realist with a slightly cynical edge, whereas Krikor, a staunch Dašnak, remained a romantic through and through. Both brothers were maternal uncles of the writer Vahan Totovents (1889-1938), who worked in the Keljiks' St. Paul rug business between semesters at the University of Wisconsin-Madison. A 1922 profile in the St. Paul Pioneer Press says that Krikor was a frequent contributor of poems and short stories to the Armenian-language American press, both newspapers and magazines. He contributed to the Boston Armenian-language Dašnak paper Hayrenik' as "Devrish." The books printed with the author's name as "Devrish" or "K. Devrish", with some description of their content courtesy of Lou Ann Matossian:

1. Tēvrišin K'eškiwrz, Boston: Hayrenik' Press, 1930. The author's first book. Contains a short novel, Bakhedjin ("The Fortune-teller") and a novella, Nouskhan ("The Locket"). Both works incorporate poems and songs.

2. Murmurs of [the] Muse, St. Paul: Devrish Press, 1941; $2^{\text {nd }}$ edition, 1949. Verse in English, dedicated to the author's daughter, Sossy Armenia Keljik, who died young. Self-published, with typography, printing and binding all done by the author's hand.

3. Žayreru žaranga ("Heir of the Rocks"), Tẽvrišin tparan (=Devrish Press), 1947.

The cover page of "A Dervish's Begging Bowl", illustrated here, affords a sense, both of the romantic image of the mystical mendicant, and of his embodiment of a longed-for convivencia of Christians and Muslims - a notion as wistfully fanciful as the picture of Muslim, Christian, and Jewish harmony in Spain before 1492 for which the term was coined. Behind the dervish in a romantically half-wild, half-paradisiacal landscape rise the pointed, Cross-topped domes of Armenian churches, one of 
of the mountain", in the Tiflis journal Mšak ("The Cultivator") No. 205, 1909. This was the comfortably liberal paper of record for the Russian Armenian community and intelligentsia, centered in the Georgian and viceregal capital- Erevan was then still a sleepy provincial town. In 1910 he settled permanently in Tiflis, working as a journalist for Mšak, Surhandak ("Express Messenger"), and Kaycer ("Sparks"). He and his Russian wife Ol'ga translated and offered for sale recent and avant-garde Russian literary works (Leonid Andreyev, Fëdor Sologub, A. Kuprin, and others) in Armenian translation, at prices ranging from three to eight kopeks - but the market proved disappointing. He also translated into Russian the works of the Armenian writers Avetis Aharonian and Levon Shant and the dramatist Shirvanzade. All this so far is a standard literary trajectory for the time and place.

But by this time he had also begun innovative experiments in writing: in 1911 he was woodenly attacked for what the critics perceived as his misuse of Armenian grammar, morphology, and syntax in his novel Eruand Gōš. He offered a spirited reply: "It is my conviction that every new writer, if he is entering the literary arena with a calling, must bring new literary forms with him, and is not to masticate and employ only that which the generations before him masticated and used." We should recall at this point that at the other pole of the Armenian world, Constantinople, the writer and poet Tiran Črak'ean (Chrakian), writing under the pen name Indra, ${ }^{8}$ had also published a novel, Nerašxarh ("The Inner World") full of neologisms and linguistic experiments - and had weathered exactly the same sort of criticism. The Black Dervish had become a Futurist.

The movement was new. Filippo Tommaso Marinetti (1876-1944) had published the first Futurist manifesto, in Italian, in $1909 ;{ }^{9}$ and his movement spread very quickly across Europe and to Russia, where in December 1912 the first Futurist anthology, Poshchëchina obshchestvennomu vkusu ("A slap in the face to public taste") was published, with contributions by Khlebnikov, Mayakovsky, David Burliuk, and others. It was a resounding slap, encouraging the young "to throw Pushkin, Dostoyevsky, Tolstoy, etc., etc., from the steamship of the contemporary (sovremennost')." In the summer, local Futurists painted their faces and paraded through St. Petersburg and Moscow, scandalizing the public. Futurism in the Russian Empire grew quickly to such importance that Marinetti himself lectured in Moscow in 1914 and lectured there. Kara Darviš summarized his remarks in a manifesto of his own, Inč' é Fut'urizmə? ("What is Futurism?"), published the very same year. (It

which is inspired by the $10^{\text {th }}$-century island church of the Holy Cross on Att'amar (Aghtamar) in lake Van.

8 The name is an anagram in Western Armenian of his first name; but as a word on its own it is also the name of a dragon-slaying (vritrahan-) Hindu god of lightning, who was akin to the Zoroastrian Vərəthraghna (the Iranian equivcalent of Indra's Vedic epithet), ancient Armenian Vahagn. We know of the later from an epic fragment about his birth preserved by the classical historian Movsēs

Xorenac'i; Kara Darviš was also to use this source for the ancient and mythological material in his Futurist verses. He and Indra reflect a widespread interest at the time in the nation's primordial, preChristian culture and way of life.

9 Translated in Umbro Apollonio, ed., Futurist Manifestos, New York: Viking, 1973, pp. 19-24. 
is translated in its entirety in an appendix here.) It is astonishing how Armenians in Tiflis, nearly a century before the Internet, stayed abreast of cultural trends in other countries this way. And there is an interesting Armenian connection to mainstream Futurism anyway. One may justly call Velimir Khlebnikov (1885-1922) the intellectual leader of the evolving movement in Russia, at least as far as its language is concerned; and he wrote in an autobiographical note, $V$ moikh zhilakh est' armyanskaya krov' (Alabovy) i krov' zaporozhtsev (Verbitskie)... prinadlezhu k mestu Vstrechi Volgi i Kaspiya morya (Sigai) "In my veins there is Armenian blood (the Alabovs) and the blood of the Zaporozhian [Cossacks] (the Verbitskys)... I belong to the place where the Volga meets the Caspian Sea (Sigai)." 10 He endowed the followers of the movement with the more Slavic name Budetlyane, "What-willbe'ers", had studied Sanskrit and other eastern languages at St. Petersburg University, and would have been, like many educated Russians, fairly knowledgeable about things Armenian, even aside from his background. But what is important as regards the work of Kara Darviš is that Khlebnikov, in collaboration with Roman Jakobson (who emigrated and in his later years worked as a Slavicist and linguist at Harvard) devised what they named zaum', or "transrational" language. Zaum' borrowed and played with folk spells, sectarian glossolalic incantations, and secret argots, as well as street sounds and nonsense syllables. A famous example is his song of the Rusalki, or undines, illustrated here. This derangement of linear, canonical language was accompanied by innovations in typography and graphic design: the Futurist movement coincided with the Cubism of Picasso and Braque, and with the Calligrammes of Apollinaire. ${ }^{11}$ The latter's poems were placed on the page in order to echo their subject as images, as drawings inseparable from poems. The poem was no longer only articulate speech, but enfranchised sound; the text itself was no longer a conventional page of horizontal, orthographic lines, but part of the art that illustrated it, even an object the reader had to manipulate in order fully to appreciate- a kinetic experiment. ${ }^{12}$

\footnotetext{
${ }^{10}$ N. Khardzhiev, ed., Velimir Khlebnikov, Neizdannye proizvedeniya ("Unpublished Works"), Moscow: Khudozhestvennaya literatura, 1940, p. 352.

11 The Futurist artists drew not only on local antiquity but also on the "primitive" art of distant regions. This was a period of intense scholarly interest in the monolithic moai and the still undeciphered Rongorongo script of Rapa Nui (Easter Island). Gauguin used Rongorongo in his painting, especially in the famous portrait of his young lover, Merahi metua no Tehamana (Tahitian, "Ancestral Guardians of Tehamana"), 1893 (see Suzanne Greub, ed., Gauguin Polynesia, Munich: Hirmer, 2011, p. 221 pl. 205, discussion on pp. 166-168); and Vasilii Kandinsky experimented with it to the end of his life: lines of his own kind of Rongorongo appear in his final, unfinished watercolor (illustrated here, from Peg Weiss, Kandinsky and Old Russia: The Artist as Ethnographer and Shaman, New Haven: Yale University Press, 1995, p. 209, pl. 202) as a kind of post-Futurist meta-text. The painter sought "an art in which a direct equivalence between sign and referent could exist, one that he believed would, in effect, be a non-discursive and universal language" (Simon Morley, Writing on the Wall: word and image in modern art, Berkeley and Los Angeles: University of California Press, 2003, p. 35). The Futurist Il'ya Zdanevich wrote a play, Ostraf Paskhi (in phoneticized Russian, translatable as something like "Easter Eyeland"), one of whose main characters is a sculptor (see Susan P. Compton, The World Backwards: Russian Futurist Books 1912-16, London: The British Library, 1978, p. 62).

${ }^{12}$ See the excursus here on visual language and Armenian magical manuscripts as a source for the design and intended kinetic qualities of Futurist texts.
} 
Kara Darviš was quickly to adapt zaum' to Armenian, using native sources and references and the urban sounds of polyglottic, exotic Tiflis, invoking also musical instruments and chords to imply an additional dimension to the sound of his poems. His poems play with different typefaces, sizes, and orientations of Armenian letters, inviting the reader to see them as pictures; the reciter, perhaps to attempt a chanted, musically experimental rendition. His poems are self-described incantations, too; and in Armenian magical texts words of known semantic value and voces mysticae - mantric "nonsense" words - are often written in different directions and patterns and in association with other graphic designs (cf. the sigils of western grimoires - that is, the ritual books of practicing witches). One recalls that Rimbaud was so disappointed that his poems did not exercise visible, magical power that he gave up writing and left France to become a gun runner and slave trader in Abyssinia. Another resident of Tiflis at the time, though, did employ both painted shapes and mystical, chanted words - some of them, Armenian - for the purpose of psychological growth and transformation, the making of a new and enlightened man. This was George Gurdjieff (1866-1949), born at Alexandropol (later Leninakan, now Kumayri, in the Republic of Armenia), ran his mystical school for a time in the city before decamping to Paris after the establishment of Soviet rule. Gurdjieff (the name is Persian for "Georgian", with a Russified ending) was completely fluent in Armenian, though his ethnicity is often given as Greek. ${ }^{13}$

The Moscow Futurists visited Tiflis in 1914- Kara Darviš, as noted above, wrote and published as a pamphlet Inč' $\bar{e}$ futurizma, "What is Futurism?" the same year. This was not just a summary of Marinetti's views, or those of the Russians, but a manifesto of his own, Armenian Futurism. Its combative, scandal-mongering style

\footnotetext{
${ }^{13}$ In his autobiographical Meetings with Remarkable Men, Gurdjieff claims his father Adash was an ashugh (musician and bard) who sang at Van and Kars, and in Karabagh, and kept alive an oral tradition of the stories of Gilgamesh. He worked for a time on the Kars-Karakilise-Tiflis railway, and claimed to have found books in the ancient and incomprehensible Armenian of Father Telvant and the Sarmoung Brotherhood: these were hidden in a cave blocked with stones in the ruins of the medieval Armenian metropolis of Ani. Elsewhere he refers to a book called Merhavat, i.e., Arm. mer hawat $\left(k^{\prime}\right)$, "our faith" (cf. perhaps the Clas. Arm. Knik' hawatoy, "Seal of faith"); and Armenisms of this kind abound in his huge tome, Beelzebub's Tales to his Grandson. There he mentions a religious festival called Zadik, i.e., Arm. Zatik, "Easter" (Voltaire had liked the Armenian word, too, cf. his Zadig); and the real name of the planet Mars is Mdnel-outianlink, with Arm. mtnel "to enter" and the abstract nominal ending in the genitive, -ut'ean. These are just examples drawn at random. Gurdjieff claimed to have seen the writings of the pythonesses of the Imastuns (cf. Arm. imastun, "wise"), which could be in four directions on a page, depending on the direction from which they were receiving a communication - this could be a reference to a multi-directional Armenian magical text. Few of the flamboyant mystic-writer-painter-musician-adventurer's claims can be verified, though; and Gurdjieff enjoyed playing games of mystification: see Colin Wilson, The Occult: A History, New York: Random House, 1971, p. 385. One way to contextualize Gurdjieff, perhaps, is to compare his wild tales, extravagant cosmologies, and polyglottic inventions to those of Ali Mirdrekvandi, whose long novels, with their mixtures of Persian, Kurdish, and possibly Mithraic and Zurvanite mythology, baffled and entranced the great Iranist R.C. Zaehner. The latter wrote a Foreword to one, No Heaven for Gunga Din (New York: E.P. Dutton, 1965); many others languish unpublished at Oxford.
} 
was doubtless intended to attract attention outside the official press; and it is a provocative attack on Armenian traditional culture, values, and morality that singles out for ridicule the beloved elder of Armenian letters, Yovhannēs T'umanean (Hovhannes Tumanian) and derides the popularity of ashugh poetry- the songs of bards such as Tiflis' son, the great Sayat' Nova. He was himself to assume that bardic mantle, declaring himself an ashugh and the authentic and unmediated voice of the Armenian people; but then, consistency is the bugbear of small minds. If the purpose was to start a fight with the establishment, it was a success. The great literary historian Garegin Lewonean (Levonian), whose works on the ashugh genre are of fundamental importance, found these assaults both trivial and offensive. He excoriated the activity of the Futurists as oyinbazut'iwn gełaruesti tačarum ("tomfoolery in the temple of fine art") and fumed in russified Armenian at their šarlatanut'iwn, šantaž ("charlatanry and blackmail") in an article in Gełaruest ("Fine Art") in 1916 that Beledian has cited. The official doctrine of Socialist Realism, with its stress on clarity and realism, and its contempt for "formalism" (art for art's sake, as it were), was to embrace Levonian and Tumanian, not by any fault of their own, and to celebrate the epic and balladic recitations of unlettered bards "from the people". And Stalinism consigned Kara Darviš and his circle to the dustbin of history - some of them, to the literal concentration camp dust (Rus. lagernaya pyl') of the Gulag.

Kara Darviš wrote his Futurist poem Šrēš-blur ("Asphodel Hill”) in 1914: it is translated an annotated here as an appendix here, and the text is provided in the illustrations. His novel Keank'i jutaka ("The Violin of Life"), 1917, which is in a conventional Eastern Armenian, attracted no attention (perhaps not surprising, considering recent events, including a world war, two revolutions in Russia, and the Armenian Genocide two years before the latter). It deals with a lonely, middle-aged Armenian broken by family bereavement and leading a weary life, whose spirits and neglected, decrepit body revive when he meets a beautiful Russian woman. Free love was very much a part of the Futurist program; but Beledian is probably right in his assertion that the Armenian writer here was inspired more by Mikhail Artsybashev's softly pornographic novel Sanin (1907) - the Fanny Hill or Lady Chatterley's Lover of its day - than by more sophisticated avant-garde works. ${ }^{14}$ Kara Darviš welcomed the Russian Revolution for its erotic as well as social and economic possibilities, thinking it was to lead the ship of humanity (on which, you recall, we had just made $19^{\text {th }}$-century Russian literature walk the plank) to dock at a siroy nawahangist, a "safe haven of love". In a lecture of 1918 or 1919 entitled "Prologue", he writes, "A great energy is acting, a great forward push is emerging and the new man, the man of the great force of thought and struggle, is being born. I side with the conviction that futurism is advancing and expanding among oppressed peoples, be that oppression moral or economic."

\footnotetext{
${ }^{14}$ This is not to downplay the nearly forgotten Russian sexual revolution of the time (overshadowed by subsequent Stalinist puritanism and the latter day hypocrisies of Russia alla putinesca), that gave us Mikhail Kuzmin's gay novel Kryl'ya ("Wings"), Nabokov père's legislative project to decriminalize homosexuality, and Nijinsky.
} 
Georgia did not unite, though, in a happy conjugal embrace with Soviet Russia, at least not at first. It declared independence as a socialist/nationalist republic ruled by the Mensheviks, ideological opponents of Lenin; so for a time Tiflis became a safe haven indeed for writers and artists who found Lenin's red terror something less than a love-fest. Kara Darviš was a habitué of the short-lived Fantastic Little Tavern, where he recited his poems and mixed with Futurists and other artists, socialites, and eccentrics, most of whom had fled the Bolsheviks. The poet wrote declamatory verses at once boastful and meek - he was, after all, a dervish - and these typify his recitations at the crowded tavern, to a friendly and appreciative audience. In his poem of 14 May 1921 "Who is the hero?" Kara Darviš declares, "The hero is the one who shatters human law and tramples it underfoot, who converses with the stars and champions their law; who goes out into the street naked and crazy and outside the crowd, treading underfoot the clothing of law and order men have worn for a thousand years. The anarchic, lawless, mad man: that is the hero."

There is something of Nietzsche's Übermensch, his Superman Zarathustra, in this, though Kara Darviš was emphatically not a Nietzschean; but what matters much more, what is so striking and poignant, is the manner in which the Armenian poet foreshadows the tremendous first verses of Allen Ginsberg's Howl, the clarion call of the Beat generation that was to transform and liberate American literature and culture irreversibly and forever: "I saw the best minds of my generation destroyed by madness, starving hysterical naked... angelheaded hipsters burning for the ancient heavenly connection to the starry dynamo in the machinery of night..." Kara Darviš' conception of Futurism is of interest in the study of the various national refractions of the movement for its critique of mainstream, "bourgeois" Armenian culture. But it has a wider and greater significance, since he proposes to undermine that sterile, hypocritical, western-oriented culture by embracing the Near Eastern music, drama, and storytelling that the Armenian masses of his day loved. In the manifesto Arewelk'a ibrew ałbiwr nor gełaruesti ew stełcagorcut'ean (Hin goynera nor p'ayli tak) ("The East as a source of new fine art and creativityOld colors with a new shine", translated as an appendix here), the poet addresses the sometimes naïve, sometimes disingenuous tendency of urbanized, sophisticated Armenians slavishly to ape the arts, letters, and fashions of the West and to deride the local, popular culture of the lower classes, with its Armenian, Iranian, and TurcoTatar roots. He repeatedly praises the popular Azeri romantic operetta Arshin Mal Alan, which Armenians everywhere adored (Western and Eastern Armenian translations were printed; and the sheet music was published in faraway America, too), but which official high culture disdained. In this analysis of a civilizational inferiority complex internalized by the East, he anticipates the similar analyses of the polemical works Gharbzadegi (Persian, "Stricken by the west", 1962), by the 
Iranian educator Jalāl Āl-e Ahmad (1923-1969); and the controversial polemic Orientalism, by Edward Said. ${ }^{15}$

The poems of Kara Darwiš composed in standard Eastern Armenian, with their generous, oceanic, fraternally loving egotism, recall Whitman (whom the Armenian poet knew) and Blake before him (whom he almost certainly did not); and his aphorisms are suffused with the spirit of Nietzsche's The Joyful Wisdom and Zarathustra. The poems that experiment with nonsense words and diverse typographies, which, as noted, he began writing the year Marinetti visited Moscow and Russian Futurists visited Tiflis, were inspired by zaum', the "transrational" language of Khlebnikov and other poets and writers. The latter drew upon the fanciful sound combinations, glossolalia, folk spells against mermaids (rusalki), and the secret language of sectarians such as the Flagellants. Accordingly, Kara Darwiš tapped the sources and resources of his own, ancient language- of Armenian mythology and oral epic preserved in the writings of the Classical historian Movsēs Xorenac' $i$, and the cadences, images, and sound patterns of Armenian incantations. He also drank of the neo-pagan springs of contemporary Western Armenian literature, especially the Het'anos erger ("Heathen Songs") of Daniel Varuzhan, who was murdered in 1915 by the Turks. His work inspired, in turn, the younger Soviet Armenian poet Yeghishe Charents, who became acquainted with him in Tiflis.

Kara Darwiš was not content merely to write poems in non-traditional form; he altered to his vision of a future art their type of production and distribution, printing them on postcards and selling them in front of the cinema and opera houses of Tiflis. The poet's friend Kostan Zarian describes the spectacle in his novel Anc'orda ew ir čamban ("The passerby and his road"): "Kara Darviš is selling his poems and postcards ${ }^{16}$ outside the doors of a big movie theater. Kara [sic! The word is an epithet, not a first name] is a unique phenomenon in our literature: a hero, and in any case a kind of rebel. He is a man standing outside the realm of social prejudice, devoid neither of talent nor of general education. The Armenian merchant, the fossilized Armenian schoolmaster, and the Armenian literati of the Caucasus, slithering from table to table in clubs and salivating, look upon him with

\footnotetext{
15 It has become de rigueur in departments of Near Eastern studies to pay homage to the late Prof. Said, but his book is disingenuous. It purports to present the Arabs as hapless victims of an imperialist Western project, supported by academics specializing in the study of the Middle East and Islam. But what he carefully neglected to mention was that in the $19^{\text {th }}$ and early $20^{\text {th }}$ century a powerful empire, Ottoman Turkey, not any Arab polity, was the political player in the region. He ignores also the mass murder of Armenian and other Christians by that Islamic state in the name of Islam, which properly outraged the conscience of the civilized world. Said was a vocal and venomous Palestinian Arab activist, and as such cannot have been expected to give Israel- his adversary- a fair hearing. But it is unacceptable that as a scholar he deliberately obscured the role of Zionism as the national liberation movement of a severely oppressed Near Eastern people facing imminent genocide. Orientalism makes important points. It may be a classic political polemic. But it is equally an example of the way not to do scholarship.

16 Literally, bac' namakner "open letters", a calque on the Russian otkrytoye pis'mo; the latter is abbreviated with a diminutive ending to otkrytka, and Arm. follows suit with bac'ik.
} 
scorn and ridicule. But he is the hero. He is the real successor to the dervishes and bards. He preserves the honor of a poet. He is our conscience."17

After the October Revolution many Russian avant-garde writers and painters emigrated, some settling for a time in Tiflis. I have noted the debt of Armenians to the Russian avant-garde, but the Russians in the Transcaucasus learned something from their hosts, too. Vasilii Kamensky's Futurist sketch map of the city, which he styles a "poem in reinforced concrete" (his famous sketch of the Sun, discussed in the Excursus on visual language here, bears the same title), notes the location of favorite hangouts, and at the foot of the drawing is a transliteration into Russian of the Armenian word erjankut'iwn, "happiness". ${ }^{18}$ So Russians and Armenian mixed and there seems to have been some linguistic interchange- not just Caucasian peoples learning and using the language of the Imperial ruler, but Russians taking a keen interest in the ancient cultures of their hosts. ${ }^{19}$ The Russian

${ }^{17}$ Erker ("Works"), Ant'ilias (Antelias, Lebanon), 1975, p. 94), cit. by Beledian 2009, pp. 196, 273. One might adumbrate here a vexing question. A man proclaimed the conscience of Armenian literature might have been expected to speak, no, scream, about the genocidal murder of the Armenians of the Ottoman Empire, taking place just across the border. The massacres of 1894-1896 were alive in memory and might have alerted public attention to this second, incomparably greater disaster. The events of 1915 and after were well known: the mass killings and deportations were the subject of British parliamentary inquiries and made the front pages of the world's papers, including The New York Times and The Boston Globe. Kara Darviš not only read the poems of Daniel Varuzhan- one of the first victims - he even used Western Armenian in writing a line in homage to him. Armenians had organized a volunteer corps in the Russian army to assist their compatriots; and refugees from Van and elsewhere were flooding into Russian Armenia. Even so, why did not the Armenian writers of Tiflis and elsewhere in the Russian Empire react and respond commensurately to the greatest catastrophe in Armenian history? Surely they had enough to occupy their attention; perhaps, too, their minds simply could not comprehend the scale of events that were still unfolding. Did the more banal human qualities of indifference to the suffering of others, a lack of empathy, play a part? 18 The map/poem is illustrated here; and see M. Rowell and D. Wye, eds, The Russian Avant-Garde Book 1910-1934, New York: Museum of Modern Art, 2002, p. 108 pl. B. The four inscriptions read: Gruziya $=$ Salami artvepe $/$ Armeniya $=$ ěrdzhankutyun $/$ Persiya $=$ Ay choban koyun $/$ Rossiya $=$ Saryn' na kitku "Georgia= greetings (next word unintelligible)/Armenia= happiness/ Persia= Hey, shepherd, sheep!/ Russia= Crew to the prow" (a rallying cry of river bandits on the Volga).

19 The itinerary of emigration ultimately took many from there to the Georgian port of Batum(i), thence to Turkey or Greece and the penury and insecurity of exile in Europe and the Americas. The hero of the novel Nawa leran vray ("The Ship upon the Mountain") by the Armenian writer Kostan Zarian, a friend of Kara Darviš, is Herian, a sea captain based in Batum. Chapter Nine of the novel is dedicated to Kara Darviš, his café, and his friends: it is translated as an appendix here. The author evokes the dire conditions of the refugees from civil war and Red terror. One of the more curious personalities and odder literary figures to pass through Batum at the time was the Russian-Jewish writer Lev Nussimbaum, born to a rich family of Baku oilmen in 1905. His family reached the port, which his biographer calls "a kind of Czarist Casablanca- the bottleneck for all those fleeing west", in 1920 and were able to purchase Georgian passports and depart for Constantinople. (See Tom Reiss, The Orientalist, New York: Random House, 2005, p. 100.) Nussimbaum converted to Islam and under the pseudonym Kurban Said published in German Ali and Nino, the love story of an aristocratic Azeri boy and a tender Georgian maiden caught up in the whirlwinds of war and relentlessly pursued by an evil, lascivious old Armenian named Nakhararian with a big black powerful car. (Naxarar, the ancient Parthian term for a local hereditary dynast, now means "government minister".) Under the pen name Essad Bey, Nussimbaum authored a pioneering biography of Stalin. Though pursued by Azeri Nazis anxious to out him as Jew, he managed to die peacefully in wartime Fascist Italy. In his 
friends of Kara Darviš published an anthology of his lyric poems and short stories in Russian translation, Pesni buntuyushchago tela ("Songs of a rebellious body") at Tiflis in 1918. (No Futurist compositions are included.) The book is a paperback brochure of mimeographed typescript: the typeset cover has a cameo photograph of the poet. It bears no fewer than four prefaces by the poet himself:

“(1) TO MAN. With a torch kindled in my soul and a smile of love on my lips I come to thee, a poor, broken, spat-upon man.

KARA-DARVISH, June 1918.

(2) TO THE PRESENT ANTHOLOGY.

The present anthology has been translated with my assistance in the form of a literal rendering into Russian of my novellas/songs. My translator-friends have expended every effort to depict the visage of the poet in its full convexity, warming their labor with great love and tenderness. It remains to me only to thank them from my soul, from my burning heart, for the opportunity to make my few works accessible to the wide Russian reading public. In the near future I hope to publish in Russian translation my longer works, as well.

KARA-DARVISH, May 1918.

(3) DEDICATED

to the friend about whom I dreamed and in whom I was ever disillusioned.

If the entire world takes up arms against my words, thoughts, and feelings, you, my friend, will be standing to the side, you will understand me, you will come up to me, and will give me your hand.

KARA-DARVISH.

(4) Whom I love.

I love those whose soul is like a shoreless sea and whose conscience rings like a silver bell.

\section{KARA-DARVISH."}

The poems in the book deal with themes of voluptuousness and love, for the most part, in a not particularly enviable style one might characterize as fin de siècle Orientalizing Symbolist-lite. For instance, on p. 48: "I became weak, and wordless, and without a moan/ I instantly awoke. The silence, pitch black./ That spellbinding lass from the land of the Pharaohs/ Veiled herself with murk from stares..." No luck for peeping toms in the land of the Pyramids. On p. 55, a lily-bodied hetaera sprawls invitingly on a Khorasan carpet: one prefers the iterations of Varuzhan and Medzarents, where she is at least dancing. The prose pieces are eminently forgettable as well: One story introduces a forest nymph who strips down for a dip in the sea in the buff. Then she dries herself off, heads back to the woods, and the sun smiles at her. In another, a man wandering in the desert dreams, plausibly, of water; then he sees a goddess standing on a mountain and acknowledges her as his Ideal. He continues on his thirsty way. A third opens on the disturbing scene of people hauling crosses up to Golgotha; but the reader's anxiety is assuaged by the assurance that they are all brothers, helping each other. (But then, to do what?) The

anxiety to conceal his origins, Nussimbaum can be compared in some ways to the Armenian Imaginist Alexander Kusikov. 
book does contain translations, by Tatiana Vechorka, of the important poems "Who I Am" and "The Cup of Life"; mostly it testifies to the esteem of the poet's Russianspeaking friends and their readiness to help his poems reach an audience beyond readers of Armenian.

These included the Russian Futurist Alexei Kruchënykh (1886-1968), who lived from early 1918 to the end of 1919 at Tiflis in the family home of his fellow Futurist Il'ya Zdanevich (1894-1975), a permanent denizen of the city. Together with the writer Igor' Terent'ev they opened in Nov. 1918 the Fantasticheskii kabachëk ("Fantastic Little Tavern"), which became a meeting place for the Russian, Georgian, and Armenian "Syndicate of Futurists", of which Kara Darviš was a founding member, till it closed its doors in July of the following year. Kara Darviš published his cycle Yurut'k' Ulunk' "Incantation Beads", including the earlier Šreš blur "Asphodel Hill", in an anthology dedicated by the habitués of the tavern to the beautiful dancer Sofia Georgievna Mel'nikova (1890-1980), the charmed center of their circle. It includes poems by Vechorka, one of the translators in Songs of a Rebellious Body. ${ }^{20}$ The Georgian poet Grigorii Robakidze, whose poems appear in the anthology, described the place: ${ }^{21}$

"Tiflis has become a fantastic city. A fantastic city needed a fantastic corner, and on one fine day, at No. 12 Rustaveli, in the courtyard, poets and artists opened a Fantastic Tavern which consisted of a small room, meant for ten to fifteen, but which, by some miracle, had about fifty people in it, more women than men. Phantasmagorias decorated the walls of the room. Virtually every evening the tavern was open and poets and artists read their poems and lectures."

One visitor to the tavern, for instance, was the famed hostess and socialite Vera Sudeikina-Stravinskaya, whose family arrived in Tiflis in April 1919 and stayed there six months. Her album includes entries by numerous painters and writers including Il'ya Zdanevich and the poet Osip Mandelstam, who translated a poem by Kara Darviš (dedicated to Robakidze) into Russian. ${ }^{22}$ The writer Konstantin Paustovsky (1892-1968) met the Zdanevich family during his stay in Tiflis, in 1923, and mentions in his memoirs a book they had entitled Tsveti, poeziya sukina doch' (perhaps best rendered now, with apologies to the gentle reader, as "Flower, 0 poetry, you fuckin' bitch"). It was printed in various typefaces, and "between

\footnotetext{
20 The volume, entitled Sofii Georgievne Mel'nikovoi, Fantasticheskii kabachëk, Tiflis, 191719181919 (“To Sofia Georgievna Mel'nikova, Fantastic Little Tavern, Tiflis, 19171918 1919”), was published in Sept. 1919 in an edition of 180 copies and included poems by Russian, Armenian, and Georgian Futurists and illustrations by Natalia Goncharova, Alexander Bazhbeuk-Melikov, Lado Gudiashvili, and others. It was reprinted in 2012 by the Georgii Leonidze State Museum of Georgian Literature, Tbilisi. All the poems by Kara Darviš printed in the volume are illustrated, translated, and annotated here.

${ }^{21}$ Cited in Susan Compton, Russian Avant-Garde Books 1917-34, Cambridge, MA: MIT Press, 1992, p. 44.

22 See John E. Bowlt, The Salon Album of Vera Sudeikin-Stravinsky, Princeton, NJ: Princeton University Press, 1995, pp. xix-xxi. The poem is translated here as an appendix, with the Russian text.
} 
individual words were inserted various lines, rows of dots, clefs, letters from the Armenian, Georgian, and Arabic alphabets, musical notes..."23 It seems likely Kara Darviš had a hand in preparation of the text. It is noteworthy that there is an element of musical notation: the variations in size and position of letters in Futurist publications suggest a musical score, so that one might attempt a tonal performance of them; and Kara Darviš refers often in his poems to music. ${ }^{24}$

The greatest and most important of the Armenian poets Kara Darviš knew in Tiflis was, as noted, the great Yeghishe Charents (1897-1937). The latter was a protean figure who, it can fairly be said, mastered and perfected every poetic style known in Armenian. He wrote poems in the styles of Symbolism and decadence in his early years, then turning to the stridently proletarian verse of the great bard of the Revolution, Mayakovsky (who was born in Georgia, and who in 1914 sketched a portrait of Kara Darviš, illustrated here). In 1920, in the midst of revolution and chaos, Charents wrote his Tałaran ("Song book"), a cycle of lyrics in the style of Sayat' Nova, in a very clear and limpid Eastern Armenian. For a time he associated with the Imaginist school in Moscow, that included the great Sergei Esenin - the Rimbaud-like bad boy of Russian poetic legend- and the curiously furtive, russified Armenian poet, Alexander Kusikov. ${ }^{25}$ Charents was to experiment with, then disavow Futurism when it fell out of favor, as he became a leading figure of the new Soviet Armenian literary establishment. But he mentions in a letter of 18 March 1934, three years before his arrest and death, that he had met Vahan Terean (Terian), the Armenian Symbolist poet, at the Chashka chayu ("Cup of Tea") in Tiflis, back in the days of the Revolution. Kara Darviš, whom he calls "the only Armenian writer whom I knew personally at that time", was there. Since there were plenty of others, the comment suggests that the Futurist poet stood out among them and that Charents sought his company and held him in high esteem, even though he was to condemn him a few years later. ${ }^{26}$

In 1921, with the Communist annexation of Georgia, Kara Darviš gamely attempted to adapt to the new order, hoping to find a niche of acceptance. He began

\footnotetext{
${ }^{23}$ Povest' o zhizni ("A tale about life"), vol. 2, Moscow, 1966, pp. 456-457, cited by Gerald Janecek, The Look of Russian Literature: Avant-Garde Visual Experiments 1900-1930, Princeton, NJ: Princeton University Press, 1984, p. 183.

24 The Russian Constructivist A.N. Chicherin in his "Change of All", 1924, introduces a novel form of musical notation that breaks with unidirectional straight lines (see Janecek 1984, p. 197 fig. 160). It is noteworthy that there is an Armenian connection to later experiments of this kind in the west. "Aria", written by by John Cage in 1960 for a singer named Ms. Berberian, has a score consisting of drawings of lines in black ink, accompanied by blotches of various colors and the words HAMPART-ZOUM (W. Arm. for Hambarjum, "Ascension", used as a man's name), DIROUHI (W. Arm. for Tiruhi, the fem. of Tēr "Lord", used as a woman's name), DI QUESTA TERRA (Italian, "of this earth"), NAPRASNO (Russian, "in vain"), CONSCIENCE ET (French, "conscience and"), and A-RISE! (English): see Theresa Sauer, Notations 21, New York: Mark Batty, 2009, p. 44.

${ }^{25}$ On Kusikov, see J.R. Russell, "Iranians, Armenians, Prince Igor, and the Lightness of Pushkin," in publication, Iran and the Caucasus, Erevan and Tehran, 2014.

${ }^{26}$ Ayn žamanak inj anjamb canot' miak hay hetinakə: Ełiše Č'arenc' (Yeghishe Charents), Erker

("Works"), Erevan: Academy of Sciences of the Armenian SSR, 1967, vol. 6, p. 480.
} 
writing on literature and theater for the paper Karmir Astt ("Red Star"); Osip Mandelstam, who was passing through Tiflis, translated his poem Para leran vray ("The Dance on the Mountain") into Russian that year. The Soviet Union was established in 1922; and in 1923, as a Soviet literary and cultural policy began to take shape, the Soviet Armenian press commenced attacks on the Futurists. On 15 November the Armenian House of Culture at Tiflis held a full-court "literary trial" of Kara Darviš, who was condemned in a seven-point verdict. Charents, Gevorg Abov, and Azat Vshtuni, a self-appointed triumvirate of official taste, declared that Futurism had no place in Armenian culture. But by the late 1930s, it was to have no place for them, either. In the twilight years of his life, Kara Darviš wrote occasionally for Mardakoč' ("The Call to Battle", Tiflis) and Hayastan ("Armenia", Erevan) till 1927. In his last months he was shuttling back and forth between Erevan and Tiflis in an unresolved dispute about his pension. One of his last poems is the wistful gaze of an old man back into the past, not forward. He saw only death ahead, and perhaps he understood also that Armenia had been robbed of its future. "Again my heart thirsts/ For its vernal spate of health;/ Again summer's the embrace/ Of the giving body of a girl.// Come come do not forget/ That in Apollo's might arms/ Great power from the past is yet.// My heart pounds again/ Like the hammer on the anvil/ And garlands of sparks / Light up the black of night./ ... Steamy summer heat/ Comes like a faraway cry/ And with a fevered heart/ I just want tea with lemon."27

He died 16 December 1930 and was buried in the Armenian cemetery of Xojavank'. Two lines from his poem Ov em es, "Who am I" are engraved on his tombstone: Es hamašxarhayin k'ałak'ac'i em,/ Ašxarhn ē im hayrenik'a ("I am a cosmopolitan citizen/ And the world is my fatherland"). ${ }^{28}$

So, Kara Darviš was the great Armenian Futurist. His career is testimony to the tragic oblivion to which historical circumstances have condemned Armenian innovators in art and thought whose contributions might otherwise have nourished the Near East and the world and advanced human progress. Had the Genocide not happened, had the October Revolution not degenerated into a sanguinary tyranny, there might have been a Europe without Hitler and a Near East without Hezbollah and Hamas. Instead, the cultures of the East might have joined as equals, not as antiquarian curiosities, the great stream of world thought. But the life of Kara Darviš is testimony, too, to the speed at which world culture reached distant Armenia in times when to be a Futurist meant to be hopeful rather than apprehensive, and to

\footnotetext{
27 Grigor Pələtean [Krikor Beledian], Haykakan Futurizm (“Armenian Futurism”), Erevan: Sargis Xač'enc', 2009, p. 268.

28 See Krikor Beledian, "Kara Darvish: A Forgotten Futurist," Raft 6, 1992, pp. 39-53; on the response to the criticism of Eruand Gōš see Beledian 2009, p. 200; on “Who is the hero?", p. 251. Beledian is the principal scholar, theorist, and critic of Armenian literature, particularly of the modern period, in France; and the groundbreaking archival work on Kara Darviš is his. I have widened the scope of analysis somewhat to understand the poet's work in a philological manner, examining his use of language and of ancient Armenian sources; and I have expanded the multi-cultural and historical context considerably. None of the poet's work itself has been translated into English hitherto; so I have endeavored to present a representative sample.
} 
the astonishing receptivity of Armenians to innovation when their conditions permitted. One might add to the valediction of his epitaph the letter, cited in an appendix here, that another great Armenian eccentric, William Saroyan, addressed posthumously to Charents. In the end, Charents and Kara Darviš alike said no to power and did not betray their muse and their inner liberty.

In his 1939 obituary article on Khodasevich, Vladimir Nabokov wrote that the personal loss was unendurable, so let us turn to the poems. Let us turn here to the texts of the manifestos, the literary evocations of that nearly forgotten time, and listen to their lost hopes, evanescent dreams, and their resurrected music.

\section{Appendices.}

1. Kara Darwiš, Bac'ikner ew antipner, aforizmner ("Postcards and unpublished [poems], aphorisms," Kam, handēs verlucakan ("Kam, an analytical journal") 6, Los Angeles, 2005, pp. 209-234. The aphorisms were selected by the editors from a total of 800; I have made a further selection here.

(210) Ov em es, "Who am I?" from the cycle "Towards new heights".

I am a crazy-minded dreamer - the stars and the moon are my dream.

I am a solid man of the earth - the earth and nature are my roots.

I am a wakeful guardian - the alert observer of all values.

I am a cosmopolitan citizen - the world is my fatherland.

I am a man, and Man is my comrade and compatriot.

I am a satrap and tyrant - the executioner of all impostors and Pharisees.

I am a slave, a lamb, a dove, and a child-

I am the servant of all the righteous and the truth-sayers, the doer of their will.

I am a fierce, proud Scythian ${ }^{29}$ — I am the first Armenian who loves the Armenian people as forty thousand brave and manly brothers. ${ }^{30}$

${ }^{29}$ The word used here is ask'anaz, from Biblical Hebrew Aškenaz, the name of one of the sons of Japheth in Genesis. The -n- might have been an early scribal error for -u-, from a form like išguza, i.e., Scythian. The Armenians numbered among their ancestors Paroyr Skayordi, i.e., Partatua the son of the Scythian, mentioned by Movsēs Xorenac'i in his genealogy of the nation; and in heroic epic legend king Artašēs (Artaxias) married the Alan princess Sat'inik, i.e., Satana, the mythical progenetrix of the Narts (see J.R. Russell, "Argawan: The Indo-European Memory of the Caucasus," Journal of Armenian Studies VIII.2, Fall 2006 [2007], pp. 110-147). These were the epic heroes of the Ossetes, or Alans, a North Iranian people related to the Scythians. Alexander Blok thought his fellow Russians Skify, Scythians; and the Polish nobility also laid romantic claims to descent from the Sarmatians, also related to the Scythians. The locus classicus for the Scythians is the Histories of Herodotus; and it is no mystery why poets advocating atavism and a return to "nature" would have sought origins for their nations in the hard-riding tribes of the Eurasian steppes. A modern British poet put it best in his quatrain "Hedonism": "After the Scythians, how advance/ In the pursuit of happiness?/ They went around in leather pants, / And every night smoked cannabis." (Thom Gunn, Boss Cupid, New York: Farrar, Straus, Giroux, 2000, p. 42.)

30 Beledian 2009, p. 277, notes that the original version read, Es dašnakc'akan em, "I am a Dashnak." The Armenian Revolutionary Federation (Hay hełap'oxakan dašnakc'ut'iwn] is a nationalist political party that dominated the first Republic of Armenia but was driven into exile after the Communist 
I am a Bolshevik - I am a democrat, a socialist, to the tips of the hairs on my head. I am an anarchist - to everything petrified I am death, thunder, and lightning. I am a maximalist - I break, tear up by the root all that is rotten, old, and stale. I am a Futurist - fiercely proud smasher of idols, the vandal who topples venerable statues from their heavy pedestals and shatters them.

I am a mad lover - I place the stamp of fiery kisses on a lovely woman's bosom and with wild arms grip her strongly in my stormy and lustful embrace.

I am everything and nothing.

I am Kara Darwiš.

\section{The Cup of Life [Kenac' bažaka]}

Let the dead bury the dead.

-The Gospel

I am a hero at the wedding feast of life.

I am a deserter from the war waged by barbaric, patriotic bandits.

I am a citizen of the democracy of the spirit [ogu hasarakapetut'ean].

The demonic cackle of ridicule on my quivering lips is for you, you citizens fattened on law and order.

And I pass through the dark, cloudy tumult of the avenues of great cities, fully armed with the shield of the spirit.

Let the sky thunder - let fire and lightning flash and crash down on my bare head.

Let the naked sword glint over my breast.

Let the slippery noose of the gallows loop and tighten at my throat - my body is weak, my spirit is strong, free, bold, soaring over the plains of an untimely death. ${ }^{31}$ My spirit is an eagle's strong pinions soaring, coursing high above stupefied, slaughtered skulls.

Howl of hatred and scorn — and a leap, a mighty leap up the dizzying mountain of skulls,

The goblet for a toast to life in my hand- dedication, song, and dance, demonic wedding...

Sing, poet! The world is a graveyard.

And let the crystalline tears of repentance stream down and pour from sockets of the skulls of the stupefied victims.

That is one peaceful cemetery, that world.

takeover; despite its socialist beginnings it subsequently adopted a stridently anti-Soviet line and in the 1930s and 40s some of its members, particularly in Europe, were associated with fascism and nazism.

31 This line anticipates, and probably partly inspired, the poem by Ełiše Č'arenc' (Charents) Mahvan tesil, "Vision of death" (1920) in which the poet sees a gallows in Erevan, describes with horror the noose, and asks to be hanged as the ransom for his people. Charents met and conversed with Kara Darwiš in Tiflis; his memoir of the encounter is cited here. 
It is night. The giant sphere of the Moon swims across the sky, its silver layers gleaming down upon me, the mad lover, standing over the vast grave pit of skulls with the cup of life foaming in my hand.

That is the monument to the dawning future [fut'ur $]^{32}$ life.

It is the road to new ascents to new heights.

And howl, and cymbal and castanet, ${ }^{33}$ and violin, and lyre, and drum, and celebration, and feast...

Gods, hear my prayer - the melody of my lips. Receive my offering, and from bygone centuries, from beneath ruins, raise the golden sunbursts of your heads.

I come from the pagan temples, and Nisibis is my fatherland. ${ }^{34}$

Sound the trumpets, strike drums and shake the castanets: life's bridegroom comes, holding the bride of the new life by her hands - the mad lover comes, with the cup of life in his hands.

The road!

The hero of the new life comes, riding his victory chariot, bearing an invitation to the new life.

Sound the trumpets, blast the horns.

Roses, flowers, laurels: scatter them, and plant them.

The conquering hero comes.

Sound the trumpets, strike the strings of the lyre!

10 May 1918

Tiflis

32 Although Russians and Armenians borrowed from Marinetti's Italian the name of their movement as Futurizm, Russians invented for themselves also a Slavic designation budetlyane, "it-will-be-ers"; and Armenian scholarship calls Futurism apagayapaštut'iwn, lit. "worship of what comes after", Kara Darwiš here seems to emphasize that the movement with the name Futurism is the future itself.

${ }^{33}$ Ew mrmuny̆, ew cncłay, ew bambir, ew jut'ak... Kara Darwiš stresses variously the musical signature of his poetry and his vision. The poem "Incantation Beads" plays upon the alliterative quality of Arm. tsntsghá, "cymbal"; and the poet's novel about a desiccated man's awakening to sexual passion and health is entitled Keank'i jut'aka, "The Violin of Life". And at the beginning of the poem "Vision of death" by Charents noted above, which these verses might have inspired, the poet's vexed heart is described as the strained chord of a t'avjutak, a viola. In Kara Darviš' story P'ošotuac jut'aka ("The dust-caked violin"), published in Surhandak, Tiflis, 25 March 1912, a mysterious violinist named Kara from the legendary medieval metropolis of Ani travels to Crimea (whither many Armenians had fled following the fall of the city to the Seljuk Turks in the $11^{\text {th }}$ century) and gives his instrument to a youth who endows it with new life.

${ }^{34}$ Baginneru mējēn ku gam-Mcbinn ē hayrenik's. The line is, markedly, in Western Armenian, and refers to the cycle Het'anos erger ("Heathen songs") and the long poem Harčə ("The Concubine"), by the W. Arm. poet Daniel Varuzhan, whose work Kara Darwiš esteemed. Nisibis (present-day Nusaybin) was an ancient center of Syriac Christianity on the southern borders of historical Armenia. Kara Darviš wrote of Varuzhan, "And when your monument is erected on the future plaza of Armenian creative thought, I, standing in the front ranks, will lug on my shoulders your bronze statue towards the Nisibis of the heathen world that you sang of and loved" (cited by Beledian 2009, pp. 280-281). 
(Untitled)

Where are you, 0 man? I celebrate you.

I see a king, a nobleman, a soldier, a worker.

I don't see you, 0 man- you're hidden away in the darkness, extinguished and unseen.

You are a burnt out candle, a dying fire, a wilted flower.

I pass through the misty, beclouded streets wrapped in dark fog:

You stare, emaciated, draped in rags, forgotten by all,

And lament your lot, lamenting and cursing the infidel world.

I approach you and clasp your chilled and desiccated hand

And with fiery lips and hot breath I kiss your bony hand.

I hear your strangled cry - it is your soul, shattered and broken, ringing.

That is a man speaking, protesting, and opposite him tramp soldiers with bayonets

shining at their shoulders,

Singing a song of pride and brotherhood, fiery-red banners snapping,

But you, 0 man, where are you, I'm searching for you.

You're in tatters, you're under the bayonets, you're under the imperial purple, you're a worker, you're a nobleman.

I'm looking for you, $\mathrm{O}$ man-you're not there.

I looked for you and found you murdered, shattered, wasted, frozen, fallen before

the powers that rule this world, your hand stretched out.

I have no money or wealth - I have nothing - I have a warm kiss, brotherly, fieryI give you that.

Don't despair, you're not alone, I'm a man, I'm with you, let that kiss enflame the dying fire of your heart and inspire you with hope.

Do not despair!

(227 f.) Selected aphorisms:

Everything (Amēn ban)

1. People, I want very little from you. Just a little bit of freedom.

2. I'm weak because I don't understand you; I'm strong because you don't understand me.

3. Children are wise; big people are stupid, and those who strive to follow and resemble them are stupider still.

4. Everything that comes out of me is valuable and true; everything that comes, not from me, but from others, is false and fake.

5. You want happiness for man? Strip him naked and let him loose on the earth.

6. Look at life with the eyes of Adam and let your sole property be the fig leaf, and you'll be happy. 
7. The freest man is the one who has nothing and knows nothing.

8. Even the lion lowers his head before the sun.

9. The world was created for me and I am lord in it.

10. Revolution at its high point of fever is a prayer for the pure and the noble, but sexual sadism is for lewd and repulsive cowards.

11. Go, don't stand still, even if you are about to make a mistake.

12. The strong one gets up last; the weak one's the first to jump.

13. Real creativity justifies everyone: king, slave, pauper, rich man, martyr, criminal, the talented and the dullard, everyone.

14. Be awake, that you be a keen sword.

15 . Write in such a way that your every line is worth a chunk of your life.

16. Ink is the sea out of which, like nymphs, my thoughts are born and emerge.

17. If even a drop of ink remain at the tip of your pen, don't let it dry up-write! So that the reader may bless and remember you.

18. Stay awake, so that life around you will not slumber.

2. Kara Darwiš, Arewelk'ə ibrew ałbiwr nor gełaruesti ew stełcagorcut'ean (Hin goynerz nor p'ayli tak) ("The East as a source of new fine art and creativity- Old colors with a new shine"), reprinted in Kayk ' Literary yearbook 3, Paris, 1993, pp. 113-120.

Creation is life's greatest joy. Just as day wakes with the early morning, the dawning of the sun, so can the life of a man, an individual, a whole people, awaken, open its eyes from slumber, when it begins to create- that is, when all the strings in the soul of a man or an entire people begin to sound with a single powerful harmony, to act - in other words, for its mind and soul to live with a strong rhythm. Mankind, you would think, has begun to wake up from its deep slumber. A new morn is dawning for mankind, when the golden rays of the rising sun illuminate the world. It is necessary to create in order to live and wake, to resound with all the strings of the soul.

Futurism has been the first and greatest stimulus of the present age: it has come to tell us that you, all of you, are poets, you are geniuses, all of you are endowed with the same energy, the same heavenly spark, and you must believe that you are the chosen of heaven - if only the conviction rest firm and steady in your hearts that you are creators of life. So, here are three men for you, sitting around and talking - and behold, they are creating a piece of life. The nations are creating big chunks of life. We too as a people are creating a big piece of life. But that piece is only one slice of the life of mankind. If you create a bad, crude, uncultivated piece, then you spoil the whole splendid edifice of man- his piece of life. Here's a building, a beautiful building, and, all of a sudden, it has shattered windows and broken ornaments. We Armenians are an ornament of the edifice of the world also. Come, let us give a marvelous shape to that ornament. Let those who view it be amazed. But to fashion this ornament, we have to do creative work. We have to start the new 
morn of our life with faith and hope. The individual is powerful in his creativity only when his environment is creating, when the environment in which the individual is living awakes. (114) The individual must sense the life that surrounds him and comprehend its intimacy to him so that he may do creative work, so that he may attach a new ornament to the edifice of the world, to build it higher, or to open a new window and gaze boldly through it at the new horizons unfolding before him.

The only ones who are afraid of every open window or aperture are those who are petrified on the finished and accepted edifice of the past- lest the blast of the icy wind chill and blow away their senile flesh. New, fresh thinking emerges out of new, fresh feelings and impressions; is it not the case that thought is condensed emotion? The more the feelings and impressions you carry within you are compressed, the more purely and powerfully crystalline your thought will become. Healthy thought is healthy feeling; and healthy feelings arise from healthy impressions, when you do not constrict them with your decayed conceptions, your backward and ossified traditions. Creativity cannot tolerate petrified ways of thinking or slavish subjection to ancient traditions. Futurism is the powerful force that is to whip and flog our mental life, to stir and disturb the world concealed within us, so that we can start moving, and advance. We write the way we feel and understand; and we say what is pleasant and comprehensible to us, because we ourselves in the first instance derive a great sense of fulfillment from creating rather than apishly imitating. And creativity is the greatest joy of life.

Rejoice that you may create; and create, that you may be happy, say I. And for that purpose one must free the mind, the brain, from the iron cage of "This is impossible" and "This is unacceptable."

\section{Karabalakh dzan blan Dublakh-dublakh.}

This is ridiculous to you, but I receive and feel pleasure from (115) the new feelings and emotions that speak powerfully within me. Perhaps that dublakh is obscure and unclear even to me, but the passion for searching, for creativity, and the refusal to submit to your slogan "This is impossible", conveys me, opens me, to new creative worlds. Our brilliant Futurist poet Koŕnak Yovsaržean has trodden this path, writing in his wonderful poema 35 "Birth pangs" [Erkunk], Hē, ui, ut, ayē. ${ }^{36}$

\footnotetext{
35 The Russian poema suggests a work longer than a lyric poem or ballad and shorter than an epic, but with something of the high seriousness of the latter.

36 The famous ancient Armenian poem preserved by Movsēs Xorenac'i on the birth of the god Vahagn contains numerous complex plays on erkn, "labor"; and one name of his temple at Aštišat, Vahevahean, suggests his worshipper might have used a ritual exclamation something like the Dionysian $e v o h \bar{e}$, formed from a diminutive of his name. This may have inspired in part the composition of Erkunk'.
} 
But in order to create one must tread known, felt, experienced paths. One's feeling of racial identity [c'ełakan ink'nazgac'um] ${ }^{37}$ must take first place. I am deeply convinced that when I pronounce the word dublakh, which has never appeared in any Armenian dictionary, I place within myself a comprehension of my race, the "voice" of the blood, the "call" of the blood. I am persuaded that all my meaningless words are not to be found in any Anglo-Saxon or Latinate tongue, but perhaps my dublakh could have been a word possessing "meaning" in the mouths of Seljuks or Mongols, or of an Urartean. ${ }^{38}$ That is the feeling of racial identity and the familiar path of creativity. The Armenian painter has to draw his lines and daub his colors in an Armenian fashion, so that his picture will be intimately familiar; and the source of his creativity, unblemished. No Frenchman could ever paint an Armenian family, or the portrait of a woman from Akhaltsikhe, ${ }^{39}$ with the kind of taste, the way of an Armenian painter. That is because the subject the Armenian painter has selected for himself is a familiar one, and his creativity is set on a known path. The same Armenian painter, who spent his childhood in some Oshakan or Khotorjur, ${ }^{40}$ is unable to convey the peasant of Champagne in a talented and intimate manner. Only the Frenchman can do that. Why is it that Repin and Makovsky draw their most intimate material from the life of Russia's present or its historic past? And why is it that our Proshian or Abovian will be of no less interest to us that the cool Ibsen or the lively Rostand? ${ }^{41}$ Proshian captures the scent of the flowers of the familiar plain and wood, their aroma. And my loquacious Proshian is a thousand times more precious to me than the lofty Western idealist Ibsen or the genius Shakespeare.

This is where I offer my most conservative slogan. Fine art must grow and develop in a free and open context, free of absolutely all sectarian concepts and modes of understanding, and, without question, on its own native soil. It is accepted to divide and recognize men according to the label stuck on their foreheads. Once upon a time (116) Grigor Artsruni saw the salvation of the Armenian people in his

\footnotetext{
${ }^{37}$ Such sentiments and terms, which are properly deeply offensive to civilized people today, were part of Armenian discourse as elsewhere. In the USA the nationalist Dashnak party controlled a C'ełakrōn (pron. Tseghagron), "Race Worship" society through the 1930s. Sometimes the intention of such terms was not racialist or fascist, but often enough it was.

${ }^{38}$ Akkadian Urartu, Hebrew Ararat: the name of the kingdom in the Armenian highlands whose nonIndo-European language predates the attestation of Armenian (an individual branch of IndoEuropean related to proto-Greek and Phrygian) in the region. The Seljuk Turks conquered most of Armenia late in the $11^{\text {th }}$ century; the Mongols, early in the $13^{\text {th }}$ century.

39 This is the name of an Armenian-speaking district now in the Republic of Georgia.

40 The town of Ōšakan, in the Republic of Armenia, is the burial place of St. Mesrop Maštoc', who invented the Armenian alphabet at the beginning of the fifth century; Xotorjur, a mountainous region in Western Armenia south of Pontus, was mainly Catholic before the 1915 Genocide eradicated its native population.

${ }^{41}$ Il'ya Repin (1844-1930), a Russian painter in the Romantic-realist style; the canvases of Vladimir Makovsky (1846-1920) are similar. Perč Pŕšean (b. Yovhannēs Tēr Arak'elean, 1837-1907) was a realist Eastern Armenian prose writer; Xač atur Abovean (1809-1848(?)), wrote in Eastern Armenian the first vernacular novel in the language, Vērk' Hayastani, "The Wounds of Armenia". Edmond Rostand (1868-1918) was a French neo-Romantic poet and playwright.
} 
journal $M s h a k,{ }^{42}$ and anybody who didn't have its label glued to his forehead was no Armenian, maybe not even a human being. The same label exists now as well. You would think people were being saved by a label, like the pairs of animals on Noah's ark, from life's universal deluge. I know some wonderfully corrupt Armenians called intellectuals who have boarded Noah's ark with a shiny brand name affixed to their foreheads and have entered the ranks of good men or holy cows. And I know wonderful, lofty men whose brows are clear as the blue sky, their hearts as open as the broad sea- but since their foreheads don't have the soap wrappers of the Baudelot or Ralle companies ${ }^{43}$ or the label of a tin sardine can, plastered to them, they have not gained admission to Noah's ark and are floundering in the worldwide flood of human stupidity and ignorance. And we, the new men, arrive like the Napoleons or Vahagns ${ }^{44}$ of Armenian thought to rip those labels to shreds and to strip the confining labels from the brows of men called [illegible word in the original text], and to reveal the genuine, pure, soapy foam. Talented men cannot be confined within the limits of politics and sectarianism. They make their own talents and they discover their own world, so that we may stand, our brows unclouded, facing the dawning of the morning sun wakening our consciousness. Life will be the cause of our joys, will inspire the consciousness of the fact that it is we who are called on to enjoy this world, to become intoxicated on the gifts of the bounty of the earth and the universe. And if we want to lead healthy and happy lives, then it is necessarily by taking from the earth that which is essential to us, to all men generally, and even at the moment of death to raise the cup of life in our hands and cry out as we die the salutation "Live long!"

For all of us, for man, good and healthy nourishment is a necessity, so that we, as human beings, may be healthy and beautiful in soul and body. When healthy food enters our stomachs and we are standing close to nature we are fortunatesince we grow, since our stature is not arrested but increases, waxes greater and stronger. Our thought must grow and strengthen in the same way; our emotions, too, cannot lag behind. For thought is condensed feeling, and thought is healthy when our nerves, our feelings, are freshened by familiar, pleasant, and cheering impressions and moods. For that reason it is necessary for us, the universal masses, to have accessible and digestible fine arts and literature. That art and literature which is accessible only to the chosen few (117) is private property, like a palace in the midst of myriad hovels. The masses have to turn from their huts to the palace of thought, and to do that one has to have accessible literature and art. But accessible, digestible art and literature can be achieved only in an environment that is familiar

\footnotetext{
42 The left-liberal Armenian newspaper Mšak ("The Cultivator") was published at Tiflis, 1872-1921, with Grigor Arcruni (1845-1892) its founding editor.

${ }^{43}$ Both are illustrated here; for a general discussion of Tsarist Russia's exquisite soap wrappers in Art Nouveau and other styles, see M. Anikst and E. Chernevich, Russian Graphic Design, 1880-1917, New York: Abbeville, 1990, esp. pp. 40-43.

${ }^{44}$ Vahagn was the Armenian equivalent of Herakles in the pre-Christian era; see the note on Erkunk above.
} 
and intimate. For me, $P e p o^{45}$ is worth a thousand times more than the famous Hamlet or Doctor Stockmann. ${ }^{46}$ Pepo is ours, it is related to us, and we understand and love it, while Hamlet and Doctor Stockmann are foreign, alien to us. The clouds massing in the mountains of Scandinavia will never be able to irrigate our plains. We are men of the East and we are accustomed to the rays of a hot sun. The pale beams of the north cannot warm us. The winds blowing out of the west cannot refresh us unless that wind comes through our familiar mountains and over our plains.

Our Proshian has his taste and aroma- in his writings I sense the taste, the smell of our wonderful grapes and peaches from the plain of Ararat; but what is there for me- and I'm not even speaking about the owner of a stall in the Armenian Bazaar or the Armenian of an Armenian Molladursun ${ }^{47}$ - in Rostand's Chanticleer or Mirabeau's Garden of Torment, where the French soul addresses me in tone alien and incomprehensible. Everything has to be natural. Let crows caw like crows, and nightingales sing their enchantments as nightingales. But woe to us, when we want to sing like nightingales if we are crows, or if we try to force a crow's squawk out of a nightingale.

Russian literature is familiar to us and we are close to Russian life, but can some Armenian Markos from Qishlaq Karapet or Molladursun understand Chekhov's humor or [Saltykov-]Shchedrin's satire? No, he cannot, not at all. He will understand Baronian's ${ }^{48}$ Baghdasar and laugh, the face of deacon Arut'ik will crease in a smile, and so will that of our stall owner in the Armenian Bazaar and that of the Armenian intellectual in his top hat. Proshians "The Moths" will move the denizen of Oshakan and the Armenian immigrant in Boston, since Armenian speech is transmitted by invisible wires, from every place to Shresh hill and the summit of Aragats, where the unwilting blossom and our familiar mandrake grow. ${ }^{49}$ That which is intimately familiar always smiles at us, while the unfamiliar and strange taxes our minds. Unfortunately, how many men know Ferdousi, the poet of the East, or Varuzhan, mighty and powerful in spirit? ${ }^{50}$ While of course a great many know

\footnotetext{
45 A play on the urban life of middle- and lower-class Tiflis Armenians of the 1870s by Gabriēl Sundukean (1825-1912); Hamo Beknazaryan directed a film based on the play in 1935.

46 A character in Ibsen's "Enemy of the People".

${ }^{47}$ A village in the Ěmmiacin district of Armenia, now called Šahumyan after an Armenian hero of the October Revolution.

48 Yakob Paronean (W. Arm. Hagop Baronian), 1843-1891, an Armenian writer and playwright from Constantinople whose work satirizes the manners and personalities of the Armenians of the Ottoman capital.

49 Šrēš blur ("Asphodel Hill") is Kara Darvish's most famous Futurist poem; Mt. Aragac is the tallest peak within the present borders of Armenia, in view of the plain of Ararat.

50 Abo'l Qāsem Ferdōsī (940-1020), was the author of the Šāh-nāme ("Book of Kings"), the national epic of Iran. Daniel Varuzhan (W. Arm. Taniel Varuzhan, b. Č'puk'k'earean, 1884-1915) was a Western Armenian poet and co-founder with Kostan Zarean (who describes an encounter with Kara Darvish in Ch. 9 of his novel "The Ship on the Mountain", partly translated here) and others of the Constantinople journal Mehean ("Temple"), which came out the first seven months of 1914: the outbreak of war put an end to the enterprise. Zarian was the motive force of the journal: his philosophy, an unabashedly fascist refraction of Nietzschean thinking, is overtly and repulsively racist and anti-Semitic. He believed that the Armenians, an "Aryan" race, share with their blood
} 
Schiller and Byron. (118) We always scorn the East. Aren't we always contemptuous of a Persian countryman and his creations when we see him, but even if the voice of a minstrel bard coming from the world of the smoking jacket, tuxedo, and top hat does not ring sweet in our ears, he still dazzles our eyes and our hearing throbs with the drumbeat of his talent. The toy civilization of the West...

We, the educated, we who are infected with the malarial jaundice of Western civilization, have learned to look with contempt upon our own culture, our art and literature, seeing a halter on the neck of every thing. Even the crow of the west seems a nightingale to us, while our peacock with crow's wings - has it not lost its European feathers? The masses are more sincere, uninfected by that malarial jaundice of European civilization. They walk by the promptings of their innards, their hearts, but for good or ill when they love something, create it, appreciate it, we have words in our dictionaries to evaluate their taste, calling their theater vulgarity, ${ }^{51}$ defining their literature as the "immoral fare of the streets", even though very often we, perched on the heights of our culture, buy tickets to that very vulgar theater and find pleasure and fulfillment in it. Who has not gone to see Arshin Mal $A{ }_{a n}{ }^{52}$, and who has not taken his fill of laughter, drinking of the waters of the heart, with those wonderful Eastern melodies? The educated inrtelligentsia, its face equipped with a pharisaical mask, makes fun of the people and the theater of the masses, deriding it and its beloved Arshin Mal Alan as immoral.

But the blood of the race has something else to say, and it speaks within. The accepted cast of mind condemns because the accepted, lofty, contemporary understanding of the public is that way. But the depths of the heart laugh, delight, and bless the hand of the creative artist. Arshin Mal Alan is that talented written work, that flower of the plains, that fine art accessible and digestible to the understanding of the masses, of the people in common. Doesn't even Kirakos in Molladursun have a demand for art? And are you going to serve up Doctor Stockmann or Wagner to satisfy it? It's just the same as feeding the stomach heavy leather strips cut from old boots and expecting it to digest them. And if Kirakos from Molladursun or that stall owner from the Armenian Bazaar turns in scorn from your Chanticleer or Hamlet, embracing with open arms Vali Ghazo, ${ }^{53}$ don't be surprised. He's known Vali Ghazo for a long time, and Ghazo is a talent he embraces, caresses, and honors. My Ghazo is much more precious to me than the Frenchman's Mounet-

brothers a genius for mythology, as opposed to the arid prophecy of Jewish religion. Christ supposedly overcame and destroyed the Jew in himself. The journal was dedicated to nativist and innovative currents in Armenian art, literature, and revolutionary thought. Varuzhan was arrested with other Armenian intellectuals of the capital in April 1915 at the start of the Genocide, and was deported and murdered with them. Zarian survived and ended his days in Soviet Armenia. On Zarian and Varuzhan see Nichanian, Mourning Philology, op. cit., esp. pp. 109f., $203 \mathrm{f}$.

${ }^{51}$ Kara Darvish uses the word balagan, from Persian via Russian, which deprecatingly denotes street theater put on with an open wooden box for the characters, something like a Punch and Judy show. 52 A 1913 Azeri comic opera popular with Armenians: the cover of an American-Armenian musical score of the opera published by Prof. James Mosgofian of Astoria, NY, it is reproduced here.

${ }^{53}$ A character in Arshin Mal Alan. 
Sully ${ }^{4}$ or the German's Possart, ${ }^{55}$ because he grew up in the sun of the East and on the East's soil. (119) Doctor Stockmann, Possart, Mounet-Sully, and Hamlet are all the same to the Armenian Krpo with his tattered trousers and hungry stomachyou might as well drape a sumptuous smoking jacket made by the Sheremetyevs'56 tailor on his bare back and stuff his starving gut with tasty sweets by Massieux. Krpo's back won't be warmed and his stomach won't be sated. The East, the East, is where the sun warms an oriental, where the breeze refreshes us. Our art and literature must be very profoundly and intimately eastern, for an oriental, so that it may occasion joy for us and be digestible and accessible to our souls and minds.

Then we will grow and flourish on our own soil and beneath the rays of our own sun, and not in a hothouse, the fire of whose furnace is stoked with coal.

\section{Kara Darvish}

1916

20 December

Tiflis

3. Kara Darwiš, Inč e e futurizma? ("What is Futurism?"), Tiflis: Tparan "Ēpōxa", Muzeiskii pereul(ok) (“Epoch” Printers, Museum Lane) No. 8, 1914.

\section{From Sayat' Nova towards Futurism. ${ }^{57}$}

New ideas, new feelings have come to the fore in all epochs, in all nations, and chiefly in nations that have attained to high culture. The backward nations are

\footnotetext{
${ }^{54}$ Jean-Sully Mounet (1841-1916), a famed French actor.

55 Ernst von Possart (1841-1921), a German actor and theater director.

56 One of the wealthiest families of the pre-Revolutionary Russian nobility.

57 The songs of the bard Sayat' Nova, d. 1795, which he recorded in his davt'ar, or notebook, in his own hand in Tatar (Azeri Turkish), Armenian, and Georgian, are considered the finest of the works of the Armenian ashughs. Since their publication and study by Akhverdian in the mid-19th century the fame of the poet steadily increased. In the late 1950s and early 60s Soviet Armenia celebrated the poet's bicentennial with numerous monographs, editions, and translations of his work. His dramatic life: initiatory dream, victory in competition with other singers, doomed love affair with a Georgian princess, exile to the monastery of Sanahin, and death at the hands of Turkish marauders- became the subject of the avant-garde Soviet Armenian director Sergei Parajanov's famous film Nran guyna ("The Color of Pomegranate"). The poet Paruyr Sevak (1924-1971) wrote his dissertation on Sayat" Nova. Sevak died in an automobile accident. His son, who survived the crash, has written to me that although the catastrophe was not orchestrated by the authorities, the Soviet regime had hounded the poet to his death. Parajanov was arrested and imprisoned by the Soviets on charges of homosexuality and foreign currency transactions (both criminalized by Stalin). So the $18^{\text {th }}$-century bard of Tiflis was not just a national icon, but the patron saint of freethinking Eastern Armenian artists as well. That makes the suggestion by Kara Darviš that the cult Sayat' Nova holds back artistic progress all the more delightfully scandalous.
} 
always more conservative and are more firmly bound to ancient traditions and customs than the enlightened and civilized nations.

And it is not surprising that the more ignorant, benighted, and backward a nation is, the more ferocious and fanatical it is in its conflict with new ideas, new feelings, and innovations generally.

Change in the philosophical world view of peoples, their taste, and their customary sentiments, is not effected easily: everything that is ancient, wasted, and sapped of its strength gives way in the face of a hard fight, a strenuous contest.

The desire to live and the sense of possessing existence, it would seem, endure even in abstract conceptions - for do they not spring from the realm of a man's feelings and thoughts, while thought itself is nothing if not compressed emotion?

But how impoverished and desolate life would be, were the new thoughts, new feelings from time to time not to form currents, streaming into and refreshing man's life, endowing their experiences with health.

Here are the Asiatic nations for you, immobile, lingering behind the progressive course of life. How monotonous and stagnant their life is!

It is true that amongst those who love color, perhaps, one might still find poetic motifs in a life of that kind; maybe in that sort of life, for the sake of stylization one might find elements for the display, the expression of the visage of a particular culture. But it is questionable how useful to the improvement of human life that culture is, how positive its aim, for all the great ethnographical interest its stylized forms present.

One does not have to be a prophet to resolve that question. Wherever movement and progress are absent, life is never capable of renewal, the conditions of life cannot improve, and the lot of men cannot be bettered.

In order to make the matter clearer, let us turn to examples. The backward nations are opposed to enlightenment, and so, too, to science. By science one means the kind of knowledge that sets life and its social conditions on forward-looking paths leading to progressive renewal. Science is taught in our diocesan and parish schools - but let life itself attest to what kind of science that is. It is a science imbibed by the students who go on to fill the ranks of the intelligentsia of our deacons and seminarians. There could be no better name for this than the one given by one of our newest poets: a "parochial intelligentsia".

Science, by changing the technological, external aspect of human life, transforms men's conceptions also with regard to the life they lead. Paring your fingernails and keeping your hair free of lice is a much more life-giving science than 
the chemistry and physics taught at an Armenian seminary. But will our educators turn their attention to such minor matters, especially those teachers draped in the toga of a German doctorate?

It is interesting to consider: Where are men more oppressed, enslaved, and subject to worse living conditions, than in the more backward nations and countries? Authentic culture and science serve above all the cause of ensuring human happiness. And all the small and large achievements that science is accomplishing and has made, serve the task and aim of situating human life in better conditions.

Most men react with displeasure or even animosity to every novelty or innovation in any sphere of life. Morality necessarily plays a great role in this.

As is well known, some of the younger representatives of the Russian Futurists, chiefly the painters, paint their own faces. That is, they paint various images (flowers, animals, and so on) on their own faces and foreheads. Youth, in the principles and faith it professes, has always been stormy and unrestrained, and always will be. One can regard this innocent behavior as mere mischief. As, indeed, the noted Futurist scholar Kulbin ${ }^{58}$ says in his lectures, that is not in the essence of Futurism and one must adopt an attitude of forgiveness to such manifestations.

But take a closer look: it's not all that true. Archaic morality slithers like a snake through the petrified concepts of mankind. Just such an intellectual and even a famous actress, face reddened by agitation as though she were in the grip of a fever, nerves taut like blue ropes on her face, set out to prove that the behavior of the Futurists - painting their faces - is morality-dissolving stupidity of the highest degree. This is not true fine art, but repulsive charlatanry, shrieked the agitated actress, evidently defending the received, recognized art of her own.

At that moment I was unable to restrain myself and said, quite simply, "So why is your own face painted and powdered?" (The lady had put on mascara.) The woman became slightly agitated, but, restraining herself, she pronounced, That is accepted. Yes. That is the very best answer I could expect: it is our morality, said I. The particular conditions and situation of life create the morality of a particular period, and that becomes the flesh and blood of the inner experiences of men. And that is the reason why when a new shift ${ }^{59}$ comes to the life of men, to propel forward a new movement, people are instantly nervous and are seized by the sentiment of contrariness, fearful lest their situation in life be disturbed, not wanting to turn their

\footnotetext{
${ }^{58}$ Nikolai Ivanovich Kul'bin (1868-1917), a Russian painter, musician, philosopher, and scholar of the avant-garde and the fine arts.

${ }^{59}$ After Arm. hrumn, Kara Darviš has in parentheses Russian sdvig. This was a watchword of Futurism that Susan Compton (The World Backwards: Russian Futurist Books 1912-16, London: The British Library, 1978, p. 21) renders as "shift".
} 
carefully ordered existence, customary aesthetic, and sundry other tastes topsyturvy.

That is the situation of a way of life centuries old, a morality structured over the centuries, that protests against new ideas and innovations, occasioning psychological disturbance and distress. This inner drama tends to be especially powerful in people at a low mental level, in benighted nations at a low cultural level. As an example for you, take the patriarchal family of olden days. The parents. How many dramas do we know from that world, when a son or daughter - the children, in a word - has acted contrary to the old, traditional customs, forms, and rules. There have been tragic consequences when the son or daughter, against their parents' will, went off after a lover. Here is a frightful protest against individuality and a struggle on behalf of individuality.

Individual uniqueness: this is what both individual men and life acquire through great struggle, wresting it away from a fortified, sedentary life. A little brook with its strong push is better that a monotonous, wide-spreading, malodorous swamp. Life is thus: a little healthy, dynamic sliver of it is more life-giving than life's monotonous and wide-spreading sea, which is great in extent but shallow in depth, motionless, and stagnant.

Even thus is morality, which has often been the cause of economic and moral collapse, furthering disintegration between two colliding conceptions, world views - old, long accepted and sanctified morality, and a new morality.

In the course of the history of diverse nations, there have been of necessity moments when there has come a mighty flood of new ideas, overcoming the entire inheritance and treasure of the earlier culture, often with the élan of a vandal smashing it to smithereens. Of course, that kind of boisterous current of new ideas can call forth great confusion and dissatisfaction, and reaction amidst the ranks of traditionalists. But the new ideas, the new concepts, as they accomplish their conquest, settle down and solidify in life, becoming the foundation stone of a new morality and a new life. The same historical phenomenon occurs in the realm of art. Innovation, the new schools of art do not easily find a place in our life, and it is only through the dark woods of persecution, under attack, that they make their way, make it through, and force back the artistic forms of an obsolete taste.

New fine art [nēō-gełaruesta], to which they assign the name Futurism, is engaged in such a battle and is passing through just such a dark wood of persecution. The opinion of the famous Russian critic and scholar of the arts, Alexander Benois, ${ }^{60}$ about this artistic trend deserve the keenest attention. Here is what he writes: "I am fully convinced that the last genuine Greeks and Romans would have felt the same thing we feel now. They fell into perplexity, seeing how all

${ }^{60}$ Alexander Nikolayevich Benois (1870-1960, Rus. Benua), a painter and art historian, one of the principal organizers and ideologues of the "World of Art" (Rus. Mir iskusstva) group. 
the world around them was being destroyed, how underground forces were digging a grave for everything that was the most beautiful, the wisest, the most sacred.

Year by year the ardor of their anger towards these vandals waned, and from year to year their fascination with the utterly strange and alien blossoms grew. Of course the Burliuks of those days would say absurd things, but they still directed their gaze to those absurdities, for hidden beneath their surface was a great and immediate, elemental power.

Surely the Burliuks ${ }^{61}$ of those times (the innovators) have been lost without a trace, but did they not bring us to the thing we now call Byzantine art, which it is now customary for us to look at with wonder and admiration? Is it not thanks to them that the face of the world has changed? And even if it has lost its wondrous clarity, still it has become deeper and more meaningful."

One can clearly conclude from these lines that even such a critic and scholar of fine art as A. Benois does not reject the usefulness of innovation, even if it is Russian Futurism, which is still totally disorganized, looking for itself. In another place Benois has some profound comments worth close attention that I consider it particularly important to cite in order to elucidate the matter. Here they are: "I confess I lack the conviction to step forward and angrily declare a crusade against them (the Futurists). Of course they are untutored, they are vandals, but perhaps it is also a good thing that they are untutored vandals. Let them work on their own for everything that exists and stands on the brink of destruction: Ein neues Leben wird aus den Ruinen blühen-A new life flowers in the midst of ruins. ${ }^{62}$ I have no personal need of their creative work - to our way of thinking it is crippled and poor. But the excitement they inject into our aesthetic life is useful and in any case it can carry one anywhere, it transports. The whole idea of culture consists in not standing still. One has to advance, not stop. Burliuk and his like press on. They are restless, excited, they infuse agitation and do not allow stagnation. But they do not really know what it's all for, and neither do we. It is quite possible that individually, in fact, they are not doing anything, but something or other is still being done, accomplished, and that new thing is expressed through strange but inevitable, useful exertions."

So here, too, is a proof spoken by the mouth of A. Benois, that the new, that innovation generally, stirs, moves, and freshens not just our aesthetic lives but even our everyday existence. For does not life, too, change in accordance with our tastes and perceptions?

\footnotetext{
${ }^{61}$ David Davidovich Burliuk (1882-1967), a founder of Russian Futurism.

62 This is a somewhat garbled citation of the verse of Schiller: Das alter stürzt, es ändert sich die Zeit,/ Und neues Leben blüht aus den Ruinen "The older falls, time changes/ And a new life flowers from the ruins."
} 
Here you have three men talking; and now they are creating a piece of life. Lifethey themselves, these men, are creators of an atmosphere and the way men are is how the atmosphere now will be. The kind of men they are: that is how the life and atmosphere they shape will be. Innovation in literature and art plays a huge role. Innovation, as we have seen, introduces excitement and disturbance into our intellectual and spiritual world; and accordingly it does not allow the possibility of statis and stagnation. Futurism, or, properly called, new fine art, has introduced such ferment and disturbance today into Russian literary and artistic life.

And, astonishingly, we too have literature and fine art, as it were, but it has always been guarded by antiquarians and dustmen from external "harmful" influences. Our ignorant, clerical press has played a big role in this, having been always a countervailing force opposing new trends, nipping in the bud every tendril, every flower of any modern literary current or influence, clasping tightly to its breast and elaborating upon the moldy dustcovers of its medieval tomes.

I recall how when eight or ten years ago modernism - Symbolism - was making its way with shaky and uncertain steps into our literature. One of critics cried, “Help! Help! Armenian literature is being corrupted!" And our petit bourgeois, ${ }^{63}$ clerical intelligentsia immediately averted its gaze from the newest "face" of literature, since the representatives of the new literary current did not belong to any of the existing big political parties or work for either of the two major newspapers of the time. Is it not the case that till now among us the stubborn conviction of the common herd ${ }^{64}$ prevails that all "talents" and "developed" men are to be found only at the two existing papers, Mšak and Horizon - and those who express themselves elsewhere than in those pages are neither writers nor talents. At the moment only by mixing with the party herd and adopting the art that smiles on the present time is it possible to be acclaimed a talent and to earn the title of a writer. A small price to pay for tasting the sweeter things of life. Yet however easy that art may be for those who have acquired the facilities of literary tightrope walking and flexibility, literature and fine art for all that have their natural ways and needs, and if in the event one does not satisfy them, both the healthy mind and authentic art will wilt and wither and waste away.

Armenian thought today has wasted away. Armenian art has wilted, because conforming to the psychology of smiling at the times, of following the herd, cannot be adequate to the task of wakening a new and fresh kind of Armenian thought and bringing forth a new Armenian art.

And that is why our life has turned into a stinking, rotten swamp whose surface is covered with a layer of green that appears to one coming from far away, who is not familiar with the situation, as an emerald meadow. But it is sufficient for the naïve stranger to set foot on the deceptive pasture for him to be sucked in, suffocated, and

\footnotetext{
${ }^{63}$ Kara Darviš here uses a loan, mešč $a n$, from Russian meshchanin.

${ }^{64} \mathrm{Arm}$. siwriwakan, pron. syuru(v)-akan, an adjectival formation from Tk. sürü, "flock, herd, gang".
} 
drowned. And the hideous croaking of the aroused frogs, filling the world with their clamor, drowns out the weak cries for help of the stranger.

Understanding this, the stranger coming from modern literature will not be misled by the green "meadow" on the horizon, but will go toward unknown horizons and seek his meadow in other climes, where even if only the first buds are sprouting, they are at least not the green of a reeking swamp. Armenian life is so decayed and stagnant that the Armenian mind has become a dry gum drained of its sap. Talent and original thought are persecuted in the public forum; and banal thoughts and banal feelings have become the by-words of Armenian progressivism. And it is not surprising that it is so, for if even the poet-president of the company of Armenian writers is capable of spending an entire night pondering the question of whether the bard Sayat' Nova was a bishop or just a celibate priest, and then, after wearing himself out at length is still unable accurately to solve that huge literary problem, ${ }^{65}$ then it can never come as a surprise that Armenian literature has become a swamp and needs bold Burliuks to come and stir up that stagnant pool, even if the aroma of that particular garden of roses makes them gag.

Over the last two or three years a literary clique that has assumed control of the Armenian literary company has expended trouble and effort to advance the bardic movement in our literature. ${ }^{66}$ And they propose, as the standard of this literature, the essentially lyric poems of the $18^{\text {th }}$-century bard Sayat' Nova, which with respect to their language and form of versification, can at best be an object of ethnographic and antiquarian interest in the time of their composition but cannot serve as the foundation stone of our literary movement now, at the present day, when the psychology of today's Armenian, particularly the urban Armenian, is entirely different from that of the Armenian or two centuries ago. In this instance it is not at all surprising that today's generation is demanding singers who sing about its own life, desires a literature and art of one's own, and is not carried away by the singsong ${ }^{67}$ of $18^{\text {th }}$-century bards.

Urban life has developed most powerfully today; and the overwhelming majority of the Armenian people live in the cities that have seen the great miracles of technology and industry: Tiflis, Baku, Rostov, Moscow, Constantinople, Alexandria, Cairo, the cities of America, etc. ${ }^{68}$ Village life, lagging behind that of the great cities,

\footnotetext{
${ }^{65}$ A swipe at the grand old man of Armenian letters in Tiflis, Yovhannēs T'umanean (Hovhannes Tumanian).

${ }^{66}$ Arm. ašułakan hosank': this "current", going back to ancient oral literature, would include Sayat' Nova but also folk poets of the early $20^{\text {th }}$ century like Jivani, whose song Jaxord ōrer (pron. Dzakhord orer, "Unlucky days") is still popular today.

${ }^{67}$ Arm. neynimnerov; Tk. neynim, a deprecatory term somewhat like English la la la or Persian dalang dalang dalang, is one Charents also liked to use in his broadsides against vulgarity in contemporary culture. It mocks the hackneyed and mindless clichés of popular songs- doggerel, three-chord wonders, elevator muzak, and all the rest of the musical and poetic kitsch that is the background noise of life.

${ }^{68} \mathrm{~A}$ strange and interesting list, demonstrative of the cognitive disconnection one often observes between the Russian and Turkish Armenias. Kara Darviš mentions the comparatively minor north
} 
is gradually crumbling as urban industry penetrates there, too. It is clear that for a man of the present moment there is a demand for a different literature, a different kind of art with its corresponding modes of thought, that speak to the soul and mind of modern man, and not a literature specific to Armenians or driven by the winds of Romanticism. The cultivators of literature who lag behind the demands of the life of the present age, and who are powerless to satisfy those demands, are the only ones who profit from the situation.

Life itself possesses the greatest power, and it will scatter to the winds those artificial birth pangs and set literature and art on the paths of authenticity. And the first indications of the trend of such paths are the expressions emerging in our literary life of those particular experiences, the ones that bring a new literature and a new art to the present generation.

Questions, questions, and more questions - like the myriad trees of a forest, they crowd around us! But let us turn to our issue, to Futurism, and explain what it is, something our wise literary sages, ${ }^{69}$ uncomprehending, keep on explaining as abnormality, even though nowadays the soundest literary normality will not pass muster with even a healthy fool.

\section{Marinetti in Moscow.}

When Marinetti was in Moscow his lectures, as we know from the papers, enjoyed thunderous success, even though the Futurists themselves adopted a

Caucasian city of Rostov (Armenian Nor Nakhichevan'); but except for Constantinople the Western Armenian cities - Smyrna, Kharpert, Tokat, Gesaria-Kayseri, Sepastia-Sivas, Malatya, DikranakertDiyarbakir, Bitlis, Mush, Van, etc.- escape his notice entirely. Nor does he seem to be aware (though this may have been only a polemical ploy) that a vast number of Armenians, again in Western Armenia (90\% of the historical territory of the country), were rural farmers, not city dwellers. As to America, by 1914 there was a significant working-class urban diaspora in the NortheastWorcester-Lynn-Boston-Pawtucket-Providence and New York. But again, there was by then a significant Armenian diaspora community of farmers in Fresno, California and environs (the great Armenian conurbations of the Los Angeles basin remained in the distant future).

${ }^{69} \mathrm{Arm}$. Xikar imastunnera. Xikar, whose name as a common noun or adjective has connoted a wise man in vernacular Armenian since medieval times (the bard Yovhannēs T'lkuranc'I uses it, for instance), is Ahiqar, the hero of a late Assyrian wisdom tale in Aramaic that entered the corpus of Biblical apocrypha. The story was popular in the East Christian world generally: Akir premudryi, "Ahiqar the exceedingly wise", was one of the manuscripts bound in the miscellany that - it is reported, since the precious volume was supposedly consumed in the great Moscow fire of 1812contained the unique copy of the great Old Russian epic Slovo o polku Igoreve, "The Lay of Igor's Campaign". It was first translated into Armenian in the $5^{\text {th }}$ century and remained popular, finding a place in the miscellany of didactic tales of wisdom and adventure called Patmut'iwn Płnje K'ałak'i ("History of the City of Brass"). That is the name of the main story in the collection, which derives from Indian and Iranian cycle of stories gathered together in Arabic as the Thousand Nights and a Night. The last edition in Classical Armenian of Patmut'iwn Płnjē K'ałak'i was printed at Tiflis in 1865. It was intended for popular entertainment and edification: another case, if one wishes to see it so, as the arbiters of literature clasping dusty medieval tomes to their breasts and forcing them upon the populace - though there is no indication anybody resisted the book, and anyway the living speech of Kara Darviš himself owes something of its rhetorical panache to it! 
thoroughly negative attitude towards him. It is sufficient to recall the letter printed in the paper from one of the most typical representatives of the Futurists, the painter Larionov, where he calls Marinetti "tasteless and vulgar"; and the message he preached, "an absurdity". And maybe that was the reason the majority liked him - that he found for himself and his listeners a common language in which to be understood. One can fairly consider this a sign of banality, ${ }^{70}$ since the apostle of a new art and movement, an innovator, has always historically stirred the taste of the public, its perceptions. It is inevitable for a clash to emerge in the world views of the innovator and the masses; few understand genuine art and it is accessible only to a few. Marinetti in this instance proved more diplomatic. In his lectures he did not issue a clarion call about the cult of war as a soul-fulfilling hygiene for the world, ${ }^{71}$ nor did he have the temerity to discuss the cowardice of Tolstoy; and, finally, he neglected to express himself on his contempt for women and his fond dream of begetting a "mechanical son".

He spoke of the healthy instincts of peoples that break away and long to press forward against the earth's forces of stasis. He spoke of the values of races, and that carried some notes of bravery yet at the same time was unexpected. He spoke of the slavish, follower, museum mentality, of arid bookishness. Finally, he said that for any tendency to emerge victorious it is necessary to unite forces, rather than split into party factions. In the end, the essence of every trend is not just in its excesses or its strange features. And all this is just as understandable, especially for us, the Russian intelligentsia (and this is to be understood as the Armenian intelligentsia also), for we are eternally, forever arguing, getting twisted in knots, trying to break all records. Look at it: anyone who doesn't get the last word in, is unable to rest easy afterwards.

Marinetti himself confesses that an ideology of Futurism has not yet been created, that it is a task for subsequent generations, and right now it is necessary to labor just for mental hygiene - the preservation of health. Futurism is and expression of contemporaneity. And one is to express mental health through the cultivation of physical strength - sport - and by boycotting museums and libraries. "Every day an adolescent boy spends in a library ${ }^{72}$ is a day lost," proclaims

\footnotetext{
${ }^{70} \mathrm{Arm}$. k'analut'ean, gen. sg., a word whose meaning I cannot find, may be a misprint for *banalut'ean "of banality", cf. Kara Darviš' use above of banal as a loan from Rus. into Arm.

${ }^{71}$ See F.T. Marinetti, Guerra sola igiene del mondo, Milano, 1915, cover illustrated in Vivien Greene, ed., Italian Futurism 1909-1944: Reconstructing the Universe, New York: Guggenheim Museum, 2014, p. 61, pl. 26. The essays in this recent exhibition catalogue examine unflinchingly the dehumanism and anti-Christianity of Marinetti in particular. The first Soviet commissar of the arts, Anatolii Lunacharsky, and the great Italian Communist theoretician Antonio Gramsci initially regarded Futurism as revolutionary; but Marinetti turned decisively towards fascism. He disapproved of the Nazi suppression of so-called entartete Kunst "degenerate art", but nevertheless followed Mussolini to the bitter end. Emilio Gentile concludes in his essay in the volume that the Futurists "were not precursors but they were prophets" of the Nazi concentration camps (pp. 65-75, 172).

72 For "library" Kara Darviš uses the most august and venerable term in the language, matenadaran, which is generally reserved for a repository of manuscripts and rare old printed books, rather than gradaran, the more quotidian public library.
} 
Marinetti; and, as an example of an ideal poet, points to a comrade of his who is a Neapolitan sans culotte ${ }^{73}$ who has never heard of Petrarch or even Dante.

And for us, infected by the diseased narcissism of the Oriental, with our slack and sickly nerves, it may be helpful to be infected by Marinetti's adolescent joie de vivre. But that religion of muscle is insufficient for living and believing.

The Aims of the Futurists in Italy.

In a relatively short time Futurism has gained numerous adherents, both teachers and students. Futurist pictures, prose, and poetry have appeared. Futurist lectures have started to be read and now Futurist fashion cabarets have sprung up. The public, quite naturally, wants to become acquainted with the essence of a new current in art. Futurism is an artistic current, even though genuine Futurism preaches the renewal of all strata of life.

It is most natural that the voices of that renewal were first heard in a country that is living through the period of its decline, a country that presents the spectacle of a gigantic cemetery, where the creation of new frames of reference for life and art died out long ago. That is Italy.

At the time when the other states of Europe were flowering - at that very time Italy was gradually declining culturally, and in the midst of that process of decline and disintegration it was by historical necessity that new, keen, convulsive forces were born. Futurism manifested as the first such force.

Futurism in Italy is a political and social movement, and is so serious that the Futurist's ringleader, Marinetti, declared his candidacy in the last parliamentary elections in Italy. Although Marinetti did not win a majority of votes, the fairly significant showing of the Futurists indicates that Marinetti's campaign was taken seriously. follows:

The political, or, to put it more precisely, social credo of Futurism is as

1. Love for one's country, and, correspondingly, hatred for Austria as Italy's most threatening and powerful neighbor.

2. Spreading urban culture, with its production, factories, and mechanized environment.

3. Militarism, as an indispensable means for a nation to acquire power with relation to other peoples.

4. Doing away with sentimentalism and possessing an iron will, both of which are essential for those creating the country anew.

5. Hatred towards philistinism, because a country needs heroes, and philistines are never capable of being heroes.

${ }^{73}$ Arm. sankliwōt. 
6. And, finally, hatred of Woman as the single source and cause of weakness, who takes away from males their best years and disposes them to inanity; and this is the case insofar as Woman herself does not evince the strength to be a hero and creative force, and is thus incapable of being the equal of the male.

This is the political and social program of the Futurists.

The Aims of Italian Futurism in Art.

In the sphere of art Italian Futurism expresses itself through the dedivination of old art. It is necessary to cut oneself off from everything old; it is necessary to get far away from museums, and if it is not feasible to do that, then one is obliged to destroy them.

So here Futurism introduces into art a thing completely new: The sermon of motion. Futurism states that life is embodied motion. Life moves forward without cease, and a powerful, ceaseless labor is being accomplished by which the city grows, the culture of the city grows, and the rural and agricultural way of life diminishes and turns to dust. So this is that side of the city: life itself, motion, which the Futurists are working to transfer, to inculcate, into art.

Futurism is an elemental phenomenon. The history of literature is uninterrupted motion and the new generation of poets is never able to rest content and satisfied with the axioms of its predecessors. The young poets instinctively desire in their verses to embody every new thing that has entered the psychology of humanity in the last decade; and for better or worse those poets are seeking to express it.

So that is the historical justification of Futurism, that spread swiftly from Italy and France to Germany and even England, and has reached even us, the Armenians, here in the Caucasus. Here I would like to pause longer than usual on Italian Futurism and chiefly on Marinetti, who is justly called the father of Italiam Futurism and is the most powerful chief and leader of the Futurist movement. Futurist philosophy is founded on personal, individualist thinking; and its aesthetic taste, on purely individual feeling. In each and every individual, there is a totally different, distinct, particular expression. From this comes the total absence of a theory, a program of the kind typical of the collectivists, for whom viewpoint and theory take first place; while the Futurist is himself the individual and his unique perception, mode of understanding, and viewpoint constitute theory. Man himself is the center of the universe, to which everything refers, as a focus - that is the entire viewpoint and theory of Futurism.

As many men there are, there are that many centers and focuses, in which every spectator relates to the world in an entirely different way, illuminating it with the beams of his particular colors and inner qualities. So this ultra- 
individualism impels the Futurists towards personal modes of thinking and creation without any kind of connection to the past. To the contrary, the entire momentum of the Futurists is directed to carving away the thick layer of bark of the past, in other words, to casting off the back of modern man the oppression, the heavy yoke of the past.

The principal goal of Futurism is to sever the tie linking the present to the past. The Italian Futurist sculptor Boccioni says, "The ghost of Michelangelo has entered me and is keeping me from creating. I must at any price free myself of this monstrous specter." Marinetti says, "Italy is oppressed beneath its great and glorious past. That past greatness sits heavy and smothers the present, and buries beneath itself the new sprouts of young geniuses."

In the glare of the past, Italy in its present eclipse looks very trivial. Marinetti does not denigrate the great creations of the past; rather, he is even pained in his very soul that they are so very great and by their greatness have held back young forces, young talents. The man of today, according to Marinetti, thinks and feels in an entirely different way, because the man of the moment, equipped with a "telephone", ${ }^{74}$ has a completely different way of thinking than his forefathers, who had no idea of telephones.

Genuine Futurism is the victory of youth and of healthy and enlightened energies. It is to renew man, instill confidence in youth, and render to our present the style, color, and visage we have lost. To make just that point, Marinetti says, "Twenty-year-old poets have gathered around me: Buzzi, Cavacchioli, Libero Altomare, Armando Mazza, Aldo Palazzeschi- on whom fame is already smiling. Together with me, through their verse and prose compositions they have been unmasking the outrageous situation that our intelligentsia has put us in with its opportunism and mediocrity, and have been calling for the need to elevate national honor, without which literature and art are impossible. One has to be infused with a free and living spirit and to feel oneself the builder of the future, rather than a slave, a worshipper buried in the dust of the past. We declare our aim to be the waging of an impassioned fight to destroy the cult of the past. Have you ever thought of the countless and innumerable dead geniuses, who crowd around and beset from every side and smother the few living ones?

Men are accustomed to think only of dead geniuses, work only on them, trade only them with each other. For them, everything is easy and prepared, the paths are smoothed out and the doors are wide open. They appear ceremoniously everywhere, pass through our cities, enter our houses, and spoil the air of our springtime with the stench of the grave. And people who live by the greatness of the

\footnotetext{
${ }^{74}$ Arm. telefon, from Rus., rather than the usual native calques heraxōs or herajayn; later in the essay, in his section on Futurist aesthetics, Kara Darviš uses telefon and heraxōs together as though they were two different instruments.
} 
past, for whom the past is one of the chief elements of their inner lives, are called Passéists. $^{75}$

In that way, the creations of past, dead geniuses and talents are bought and sold and used up, but as far as the living are concerned, their lot is just contempt, insult, and abuse. The young - that is whom we are fighting for, because they are the liveliest of the live. The young - whose lot is starvation. One has to say that the money which is spent on art in Italy is being collected in the tightly sewn up pockets of gravediggers. I regard as such the Passéist publishers, professors, scholarly and powerless critics [Arm. kritnkosnerin: perhaps a typo- J.R.R.] with their base mercantile spirit and their envious slander, against which we are fighting."

Isn't the situation with us about the same? Don't we, too, have the crude critic who approaches newly-sprouted, newly-budding Armenian belles lettres and its representatives with his primitive taste and clumsy bricklayer's fingers, especially if they have been cast overboard from the safety of the existing great ships- our newspapers? Aren't all talented and learned people secured like the animals, pair by pair, of the patriarch Noah's ark, in those ships? And on the other side, aren't our publishers the very same Passéists? Don't we, too, have all our companies and accumulated funds just to publish nothing but Khorenats' is and Agathangeloses? ${ }^{76}$ And haven't we got so-called scholars working specifically on them, whose entire métier and raison d'être is to find the tail that fell off a letter $a t^{\prime}$ ? $^{77}$ We have publishing companies and organizations that are Passéist in the broadest possible sense of the word. They consider publishing the writings of a budding writer as throwing their money away down a hole. But they are quite capable of publishing the works of any writer who has accumulated enough dust to be consigned to a museum of antiquities, or a translation of any talent recognized in Europe- all of which become equally tasty food for mice on the dusty shelves of library stacks. For the present generation demands fresh mental nourishment - that is to say, the literature of now, and the singers of life the way it is now.

And in the days of domination by those profiteering from the past, declaims Marinetti, they kill every day any poet of genius, hurling at his head the desiccated

\footnotetext{
75 This is an Armenized version of the French translation of Italian passatista, rendered "traditionalist" in Greene, Italian Futurism, p. 170.

76 The Patmut'iwn Hayoc' ("History of the Armenians") of Movsēs Xorenac'i, the deeply revered patmahayr ("father of history") of the nation, is the classical text in which Kara Derviš himself found most of the epic and mythological material he used in his poems. The great critical edition of Xorenac' $i$ that is still authoritative was published at Tiflis in 1913 by Manuk Abełean and S. Yarut'iwnean so the remark is topical (as well as unfair). The Patmut'iwn Hayoc'attributed to the mysterious "bringer of good tidings" (Gk. Agathangelos, Arm. Agat'angełos) chronicles the conversion by St. Gregory the Illuminator of the Armenians early in the fourth century to Christianity and contains his Teaching (vardapetut'iwn). The critical edition of that central text of the nation's history, also still the authoritative edition, was likewise published at Tiflis, 1909, by G. Tēr-Mkrtč'ean and S. Kanayeanc'. Both books were printed in the series Patmagirk' Hayoc'("Armenian Historiographers"), edited by the great lexicographer Step'an Malxaseanc'.

77 That is, the vowel $a$ in the Armenian alphabet: Kara Darvišs version of the "least jot and tittle".
} 
mummy of some great poet of five centuries ago. The publishers toss the manuscript of a starving talent into the wastepaper basket and spend their money on the publication of masterpieces that are already well known. More than well known. And already published a hundred times over. America's billionaires, excited by grave-digger ad men, flock to Italy and pay insane sums for any work whose chief value consists in its having been buried in dust and muck that have entombed this precious morsel of past centuries.

The cult of the worship of antiquity has spread universally, even amongst us. For although we don't have billionaires, don't we still collect hundreds of thousands to erect an ethnographical palace where excavated stone vessels and bits of old, rotten wood and rusty nails are to be kept ${ }^{78}$ While our talented artists and writers are perishing of starvation.

Our poetry is completely unfettered, free and spontaneously flowing as the eruption of a volcano, as fire. One must tear up the rails of verse - of rhyme- and blow up the bridges of the "already said" (Rus. uzh skazannago) and let loose the locomotive of inspiration to traverse new and unknown plains. ${ }^{79} \mathrm{~A}$ smash up is better than a familiar, monotonous trip, says Marinetti.

All freedoms and every kind of progress have to be on a national level. We glorify patriotism. We sing of war, that tremendous conflagration of enthusiasm and greatness of soul, without which the races are fettered, ossified in soporific narcissism and a base, corrupt poverty and stinginess - says Marinetti again.

We scorn and condemn the tyranny of love and of erotic charm-a tribulation that saps the energy among us, the Latin races.

In this respect, we men of the east, one must admit, are not lacking in the qualities of the Latins.

All these burning, moving, dynamic ideas, says Marinetti somewhere else, incite and stir the public. But we are convinced that there is nothing so base and trivial as giving pleasure and satisfaction to the public, as stroking its crude, traditional tastes. That is why we want to please and satisfy only our own, great Futurist ideal; and at the present time we demand nothing of the public, which is hostilely disposed towards us, save jeering whistles.

\footnotetext{
78 Having savaged the extraordinary monuments of Armenian philology published at Tiflis at the time, Kara Darviš now takes aim at the study of Armenian folklore and anthropology. Again, the time and place produced the enduring works on the subject, such as the periodical Azgagrakan handēs ("Ethnographical review").

79 The locomotive, like the steamship, is a potent metaphor of modernity of the time. Nash parovoz vperëd gudi, v kommune ostanovka, exults a song of the Russian Revolution. "Forward, whistle, our locomotive-/ Next stop, the Commune!"
} 
And as a counterweight to that whistling, Marinetti, as a Futurist with a profound belief in the "greatness of beauty", says in his novel Mafarka the Futurist: ${ }^{80}$ "I alone dare to write this masterpiece; and it will die, too, by my hand, when the waxing splendor and magnificence of the world render it superfluous and unnecessary. Whatever the residents of Podagra and Stroke may say, it unfurls with a roar on the highest mountaintop, as the banner of the immortality of human thought, driven by the gale of glory. And my pride, the pride of a creator, is satisfied." The hero of the novel says at one point, "Our spirit, as the highest expression of ordered, living matter, throughout all its metamorphoses follows that same matter, preserving in its new forms its past emotions, the delicate vibrations of its developed energy. And let the actions of the stormy will of our life be impelled towards splendor and magnificence. From risk to risk, ceaselessly circling death, which with its rough kisses will render all the fragments recalled above immortal, in their entire beauty."

A sacrifice! A sacrifice! Cries Marinetti elsewhere. And truly, he says, we desire that the work of art be incinerated together with the corpse of its creator. That which endures after the death of its author infects living geniuses with sorrow, pensiveness, and a treacherous wisdom. Florence is one titanic medieval folio volume that has fallen with a thud upon the happiest place on earth.

\section{The Attitude of the Futurists towards War and Women.}

We affirm as a general principle of Futurism man's unceasing and endless physiological and intellectual progress. We do not accept the friendly integration of nations, and recognize for the world only one form of public hygiene: War- says Marinetti at another point.

Marinetti expresses the hatred and contempt of the Italian Futurists towards Woman this way: "Yes! We despise Woman, that reservoir of love, that instrument of voluptuous passion, Woman the poison, Woman the tragic plaything. We despise that fragile, brittle, intoxicating, lethal Woman - dreamlike Woman, at once aglow and misted in the moonlight, her smothering, fateful voice meandering amidst the trees of the forest. We despise terrible, dangerous Love, which enfeebles the progress of mankind and hinders man from breaking out of his humanity that he might redouble and surpass himself, that he might become what we call multiplied man. We are convinced that Love, emotion, and sensual pleasure are the least natural things in the world. Only the continuation of generations is natural. Love, romantic infatuation, and sensuality are the immediate concoction of poets, bestowed upon mankind. The poets are to take it back from mankind then, too. The tragicomic experience of love is close to its end, because it has never brought any benefit, but to the contrary has visited upon us innumerable evils. Now we Futurists (says Marinetti) are driving love, that literary product, far away. In their effort at emancipation the Suffragettes are our best associates, since the more rights and

\footnotetext{
80 Arm. Fut'urist Makart.
} 
power a woman acquires, the more rarely will she resort to love and the faster she will give up being sentimental, from being the hearth of the black satisfaction of desire. Especially since that monstrous development of female excess will make Love a slave who will display lesser or greater outbursts of rebellion only beneath the repressive fist of money."

Multiplication Man and the Kingdom of the Machine.

The worship of machines has begotten among the Futurists the idea that it is possible to increase and multiply man's energies, to make him a machine.

We preach a great and new idea that exists and is current in contemporary life: that is, the idea of mechanical beauty. We praise love for the machine- says Marinetti.

That love already exists in life. You have certainly chanced to witness the love and tenderness with which the engine driver of a locomotive washes down his machine's giant body. Often you'll hear from the owners of automobiles or the manager of a factory that motors are a riddle. They seem to possess soul and will, and it is necessary to flatter them, to win their love over, to fuss over them and never to mistreat them roughly or fail to care for them. And if you act accordingly with them you'll see right away how much more productive they become, performing two or three times better than before.

It is necessary, the Italian Futurists say, to equate men with machines. Man is to have mechanical intuition and rhythm, instinct and discipline like a machinequalities unknown at the moment to the majority and understood only by the most penetrating brains.

Receiving Lamarck's hypothesis of transformation in this manner, the Futurists dream of creating an un-human type (this is not Nietzsche's Übermensch) ${ }^{81}$ In it all moral torments will be annihilated, exhausted: goodness, tenderness, love - as they say - all of which poison our inexhaustible life energy and obstruct the mighty physiological electricity within us.

We believe - the Futurists declare - in innumerable transformations of man and proclaim without a smile that wings are slumbering within the human body. The non-human, elemental, mechanical type is to possess the swiftness to reach everywhere; so it is natural that he is to become cruel, all knowing, warlike, combative, and struggling. And in order that we may prepare that non-human, mechanical, multiplication type, the Futurists say, it is necessary to reduce in an

81 That is, "Superman", tranliterated into Armenian as Hubermenš and left untranslated. Subsequently however, in his critique of Nietzsche, Kara Darviš translates the term into Arm. with the calque germard. 
extraordinary fashion the feelings that bind and fetter man, but which live still in man's blood.

The Attitude of the Futurists towards the Symbolists.

We reject the Symbolists, our teachers, the last lovers of the moon, cry out the Futurists. We sacrificed everything to our Futurist conception of life and that is why you'll easily understand why we now detest our glorious intellectual fathers, whom we used to love beyond measure, those Symbolist talents: Edgar (Allan) Poe, Baudelaire, Mallarmé, and Verlaine.

Now we find them an obstruction because they floated down the current of time's river, constantly craning their heads backward. One of those head turners emerged as our own poet Vahan Terian, ${ }^{82}$ who put on the latest duds and plunged up to the cuff in the dust-choked Armenian catacomb but instead of cleaning out the dusty mummies he started snogging with them. Traditions are still strong, it seems, among these most up to date poets. They turn back towards the distant, deep Wellspring of the past, the skies of yesteryear, where beauty is flowering. For them there is no such thing as poetry without grief, without summoning back past times, without the fog of history and legend.

We hate the Symbolist masters - we who have dared to emerge naked from time's river.

We sing the swelling victory of the machine, which they stupidly hate.

Our Symbolist fathers are infected with a craving that we consider risible, that is, a desire for eternal things, a striving for the eternal, for that which does not pass away. But we think the contrary: there is nothing lower or more pitiful than to think about immortality. It is necessary to create without prizes, without thinking that one will be rewarded or that one's creation will outlive one as an actual witness. We counter the poetry of wistful expectation with the poetry of ardent expectation. We counter beauty inclining tenderly over tombs with the bold, sharp profiles of pilots and drivers of cars. We counter the conception of the permanent and eternal with the concepts of the transitory, of destruction, of ephemerality in art.

We transform Edgar (Allan) Poe's bitter joy, the nevermore [thus in the text, in English - J.R.R.] by loving and teachin the beauty of feeling and emotion, since those things are unique and are fated $a b$ initio to irrevocable obliteration.

\footnotetext{
82 Vahan Tērean (Teryan, Terian), 1885-1920, the most lyrically powerful Eastern Armenian Symbolist, inspired Charents with his vision of a spectrally supernal, ideal, or lost Armenia to which he gave the name of the ancient Urartean kingdoms, Nairi. Charents in the throes of youthful revolutionary fervor sometimes ridiculed the poet, but found the idea of Nairi infinitely fertile in his own writing and returned to Teryan's verses with reverence and remorse in maturity.
} 
In our eyes history is an inevitable falsifier, or at the least just a collection of postage stamps, medals, and counterfeit coins. The past is baser and of less value than the future. So we are able to recognize amongst our foes that ferociously deceitful and hateful care for the past, as the most dangerous servitude. We sing of the speed of machines, which demolishes the poetry of the distance of wild deserts. And we sing of and praise railway bridges, the huge pipes of turbines, those muscles of the earth, that giant mechanical movement of the earth, for it destroys the earth's diseased sensibilities.

Futurist lyricism is the eternal dynamism of the mind: energy is movement. It is the unending flow of mental pictures and sounds, and it is only Futurist lyricism that can express the inconstant, infirm, and symphonic universe that is being forged with us and in us.

\section{Nietzsche and the Futurists.}

The Futurists also reject Nietzsche, and the supposition some hold that there are Nietzschean elements in the Futurist world view is mistaken. The English press even terms the Futurists Nietzscheans, while Marinetti in his book protests against this.

But it is sufficient to become acquainted with the body of the work of the great German philosopher to be persuaded that his superman comes out of the cult of Greek tragedy. This introduces the supposition that Nietasche has a retrograde desire for paganism amd mythology. And despite his strivings towards the future Nietzsche remains one of the most ardent defenders of the greatness and beauty of antiquity. His superman is of Hellenic origin and is a fusing-together of three decomposing corpses: Apollo, Mars, and Bacchus. This is a mélange of elegant beauty, warring force, and Dionysian ecstasy, of the sort Classical art displays. We counter this Superman hatched in the dust of Greek libraries with man multiplied upon himself, who is the enemy of the book and the friend of personal experience, a pupil of the machine, ardently exercising his own will, and in the glow of his own inspiration the possessor of a cat's sensitivity, a lightning bolt's comprehension, a wild beast's instinct and intuition, with both craftiness and lack of common sense as well.

And you will wage a desperate fight, say the Futurists, against the three irreconcilable enemies and destroyers of art, which are: imitation, good sense, and money. They bring art and cowardice to the same end point. Cowardice: with respect to remarkable copies and received formulas. Cowardice: when one faces the imperative to be loved and the terror of destitution.

Futurist aesthetics. 
Futurist aesthetics, too, have been transformed; and in place of the idealized aesthetics of the man of the past, there has come a mechanical, technological, so to speak, aesthetic. That is, an emerging aesthetics of great locomotives, tunnels, battleships, airplanes, automobiles, and other technological wonders. Futurists have created a new aesthetics of speed, practically eradicating the concept of distance and greatly reducing the concept of time. The steam locomotive, the airplane, the telephone, the wireless, and so on now easily perform that function of speed and are transforming the concept of time and space. In this manner multiplication man is being readied everywhere.

Of course enrapture with such a process has also brought forth the principle of cruelty, and here is what Marinetti says: There is no better thing than planks and pillars lying about a house in construction, with their rhythm of cranes and hammers and the occasional cry of a falling worker with great gobbets of blood gushing from him. Be afraid of the decayed past, says Marinetti: In every thing, hope in the future. Have faith in progress, which is always just, even when it errs, for it expresses movement, struggle, and hope. Be careful of being drawn into a conspiracy with progress. Let progress be deceptive, a scoundrel, a thief- it is still just.

This is the cruel paganism that is expressed in the name of progress. Italian Futurism, although it is opposed to Nietzschean philosophy, is still constructing its world view on the foundation of Roman paganism and is wakening from the murk of centuries the ancient, cruel Rome of Nero.

But one of the most striking symbols of Futurism comes from Japan, where the firmest, most potent coal ${ }^{83}$ is being produced from human bones and used in factories to produce the most explosive products. However crude this conception may be, however offensive to one's sensibilities, still it is comprehensible in the name of progress. Particularly where the cult of motion is being promoted and where man as machine is the ideal, existence cannot have any sentimental lyricism, even if your loved one's bones in the form of coal are heating the tea in your samovar.

One must also not forget that Futurism expresses itself in completely idiosyncratic forms among various nations. Thus, Russian Futurism is quite different from the Italian variety. Racial identity plays a great role in this instance.

\section{Futurist painting.}

The views and principles espoused by the Italian painters, by which one means, of course, Futurist painters, are interesting with respect to the most recent Futurist art. A growing interest in the truth, they say, can no longer be expressed in form and color the same way as these were understood hitherto. The gesture we

83 Tk. komur, with Arm. acux added by way of explanation. 
want to portray on the canvas can no longer be a fixed photographic moment of cosmic dynamism. And really everything moves, everything runs, everything is being shaped swiftly. Moving subjects multiply, change shape, and continue like a vibration over space. This way, a galloping horse has not four legs but twenty; and their motion is triangular in shape.

Everything in art is conditional, and there is no general rule in painting. That which was true for the painters of yesterday now comes out as an untruth, a lie. For instance the Futurists declare that a picture of something should not resemble it, its nature, that the painter carries landscapes within him that he wishes to photograph onto the canvas.

Just as the individual scrutiny of the human spirit has swept away the static darkness of dogma, in the same manner the life-giving deluge of science will soon liberate painting from academic traditions. Whatever the case, say the Futurists, we desire to return towards life. Science in our day, in its victorious advance, has rejected its past, so that it might be better equipped to answer the material concerns of our time. We desire that art, shunning its past, might at last be able to answer the intellectual demands that excite us. Our renewed science does not permit us to consider man the center of the life of the universe. Human sorrow is about as interesting in our eyes as the sorrow felt by a light bulb.

When a man becomes a machine, when feeling within it changes into a product, when his spiritual attachments are severed and he lives moment to moment, then these are already the characteristics of the future "mechanical son". In order to grasp and understand the beauty of Futurist pictures, the human soul has to be purified, the eye must be freed of its lid of atavism - its primordial type - and of culture; and the sole control is finally to be nature, not the museum.

\section{Futurist music.}

As we saw, creativity is paramount in Futurist art; and the first condition of creativity is freedom. Futurism is opposed to academism; and for the sake of individual initiative and untrammeled individual expression it dissolves all those rules that are in one way or another present an obstacle, or that fetter free expression.

From here comes free music, which seeks ways now to express voices, sounds that are not in the power of normal music. Thus, for instance, the music of nature: light, lightning, the sound of the wind, noise, the rush of water, and with that also the urban stridor and the din of machinery. All these, as we know, choose their sounds freely. The nightingale sings wonderfully; but not with the notes of contemporary music alone. It sings, rather, with all the sounds that please it. One makes free music by the same laws that govern the music of nature, indeed all the art of nature. The free musical artist, just like the nightingale, is not confined to 
tones and halftones. He can use quartertones and eighths and such music as is free for his choosing in its sounds.

As a beginning, quartertones are coming into use. These tones still exist in ancient Indian music and are employed by eastern instruments, especially on the chonguri. ${ }^{84}$ Thus the advantage of free music consists of the following: the pleasure derived from the new and unprecedented juxtaposition of sounds; new harmonies with new chords; new dissonances with their new solutions; and new melodies.

4. Kara Darvish, Horut'k' ulunk' ("Incantation Beads"): Du dewuk p'ok'rik ("You, little demon, little one"), Jun jnjan, Čaxrēr i čaxr ("Soared into soaring"), Šrēš-blur ("Asphodel Hill"), in Sofii Georgievne Mel'nikovoi, Fantasticheskii kabachëk, Tiflis 191719181919 ("To Sofia Georgievna Mel'nikova, The Fantastic Little Tavern, Tiflis 191719181919 ”), pp. 69-77. I attempt a translation here of the semantic parts of the poems, with a discussion of the transrational words and mythological allusions.

(70) [Epigraph, in Russian] The poet Kara Darvish greets Sofia Georgievna from the summit, stained with his heart's blood, of snowy Ararat.

\section{(71) Incantation Beads [Horut'k' Ulunk $]^{85}$}

(72) [Caption to illustration, in Russian] Sigismund Valishevsky: Kara Darvish offers his verses to S.G. Mel'nikova (watercolor, 1919)

(73) You petty demoN 86

\footnotetext{
${ }^{84}$ Arm. čianuri, perhaps a misprint. The chonguri (Georgian; Azeri choghur) is a long-necked string instrument common throughout the Caucasus. The bard Sayat' Nova played it, though his favorite instrument was the bowed kamancha.

85 The locus classicus for these words is the famous story of Semiramis and the Armenian king Ara the Beautiful: in Movsēs Xorenac'i I.18, the Assyrian queen casts her zyurut'sn i cov "talismans into the sea", which the historian considers the origin of what he calls the common expression ulunk' Šamiramay i cov, "the beads of Šamiram [Semiramis] into the sea" (see J.R. Russell, Zoroastrianism in Armenia, Cambridge, MA, 1987, p. 443 with refs.). Xorenac'i explains repeatedly that he learned such myths and poems from listening to the recitations of the gusank' (a Parthian loan-word referring to bards and minstrels; it was later largely replaced by an Arabic loan via Turkish, $a$ šut, pronounced ashugh, literally "lover"), to the accompaniment of the p'andurn, a stringed instrument. The poem of Kara Darviš is meant to be modeled on spells and folk poetry, as kindred Russian Futurist verses were; and Beledian 2009, pp. 273-274, notes that the poet called the postcards with his transrational verses printed on them (роёza-)t'ovč'ank'ner, "(poetic) charms" and reminds us that called himself hŕč'akawor hay-gusan-futurist "the famous Armenian-bard-futurist". (How far is he, really, from the bardic boasts of Allen Ginsberg, a scant two generations on?) The poet appreciated alliteration of the Arm. synonyms in the two Classical expressions as is intrinsically poetic; and with his strong belief in freeing the sexual urge, he would have appreciated the robust passion of the Assyrian queen for the young Armenian, so like Dido's love of Aeneas.

${ }^{86}$ Cf. the novel Melkii bes ("The Petty Demon"), by Fëdor Sologub (1863-1927), published in 1905. Kara Darvish, as noted at the beginning of this study, advertised his translations from Russian into
} 


\author{
zaranDZar errant \\ YoU *little baT of the darK \\ faranar at the dOor \\ defile of crevAsses \\ and far from the dark'S midst \\ youareplaying waterlily [nunufar] \\ you are the wheel's squeak; \\ you are the Flute's trill \\ arAndzar of a Solo song \\ sonG dance zarangar \\ your vOice Mar Abgar ${ }^{87}$ \\ *Rome morom string [lar] \\ Single note [mialar] note of spring [garunlar] ${ }^{88}$
}

(74)

DZun [cf. dziun, "snow"]
ōndzn
ndzin

DZndzanN [cf. tsntsgha, "cymbal" and ts'ntsal "rejoice"?] ${ }^{89}$

DZndzandzN

DZandzN

DZōndzaN

Ho- $\dot{r} O-M$

Ho-ro-M

Armenian. These include Sologub's novella entitled "The Golden Stairs" (probably a part of the novel Slashche Ada, "Sweeter than Hell", 1912), price 8 kopeks, available from Akop Gendzhian, Yelizavetinskaya 114, Tiflis.

${ }^{87}$ Mar is the honorific in Syriac of a saint or monk; Abgar was the king of the Syriac-speaking citystate of Edessa (modern Urfa), claimed by the Armenians as one of our own. He was in legend the first ruler to accept Christ.

88 There are two groups of words with alliterative patterns forming the text of this spell. The first and longer is attached to the flute (sring); the shorter second, to the single voice (menerg). A pattern of nonsense words suggesting the ringing of a bell or cymbal follows thereafter. The spell has thus a musical as well as a verbal sound signature.

I. Zarandzar, faranar, k'arandzav, far, nunufar, arandzar, zarangar. These contain Persian elements: zarr "gold", nunufar "waterlily", and possibly farr "glory"; the word dzar in Arm. is the hair of the tail or mane of a horse, and is often sworn by in spells invoking the three mounted saints, Sergius, George, and Theodore. These saints' martial aspect recommended them to the Armenians, always fond of heroic epics. They are thus popular and such spells are numerous: see Sargis Harut'yunyan, Hay hmayakan ev žołovrdakan ałot'k'ner ("Armenian Incantations and Folk Prayers"), Erevan: Erevan University Press, 2006, pp. 106, 147-149, and 160.

II. Lar, mialar, garunlar. The Arm. word lar means a string of an instrument or a note that is played; but as an ending with garun, "spring", it looks like the common pl. ending in Turkish. There is also an obvious phonetic and semantic affinity of dzar, a horse hair, to lar, a musical string.

${ }^{89}$ On bells and their sound and echo in Armenian poetry see J.R. Russell, "The Bells: From Poe to Sardarapat," Journal of the Society for Armenian Studies 21 (2012), pp. 127-168. 
Pu-pU

Pu-pU

Aión i $m U$

Jurm i ǰarm [cf. jerm “warm”?]

ISॅ̆arm erased [ǰnǰēr] ${ }^{90}$

ISagarn i hArz

Entered $i$ p'arz

(75) SOARED INTO SOAR [čaxrēr i čaxr $]^{91}$

seized [brinerr] $i k^{\prime} a x r$

hearded into news [luêr i lur; the first word is aor. stem lu- of lsem "hear" + impf.]

entered the furnace [mtēr i $\left.p^{\prime} u \dot{r}\right]^{92}$

zarp'arb i zarb

furt'èr i farfr ${ }^{93}$

zurt'ér i zarfr

$z r t^{\prime} e \bar{r} z t^{\prime} a r$

Dubēr Dpar

i harb Zak'ar [Clas. Arm. "into by means of father Zacharias"!]

zurt'n zat'ar

(76) Asphodel Hill $[\check{S} R \bar{E} \check{S}-B L U R]^{94}$

${ }^{90}$ Erasure is part of some spells, cf. Harut'yunyan 2006, p. 95 no. 50a: Surbn T'oros nsteal grēr ew darjeal ǰnjēer;/ ew č́arakan patarēer;/ iwr mits xarakan kurasc'i;/ xažakan xawari;/ druc'akan c'amak'i;/ Ałi, małi, kamarxi "Saint T"oros, seated, wrote and again erased;/ and the evil eye he tore to shreds;/ That eye be pierced and blinded;/ That blue eye be darkened;/ That eye be out and dry;/ Afi, mati, kəmərxi [voces mysticae]."

91 The subsequent nonsense lines of the stanza, which emphasize the sound $f$, exotic to Arm. but common in Persian and other Islamicate tongues, preserve the Classical Arm. syntactic structure of $3^{\text {rd }}$ pers. sg. impf. verb + prep. $i$ "into" + obj. in acc., except for the final verse, with Clas. Arm. acc. def. marker $z-$.

92 Perhaps a reference to the three Hebrew children in the fiery furnace in the Book of Daniel; two, Setrak and Misak', are popular Armenian names.

93 The sound f exists in Armenian dialects and a letter representing it was introduced into the alphabet in the $12^{\text {th }}$ century; but it is not found in Classical Armenian and has retained a sense of foreignness and exoticism. Thus, when an Armenian in Georgia in the $18^{\text {th }}$ century invented an artificial language, which he called $\dot{R}(\mathrm{u})$ štuni- after a region south of Lake Van whose argot was famous - he made it as un-Armenian-sounding as possible by using lots of f's and ö's (see J.R. Russell, "Armenian Secret and Invented Languages and Argots," Acta Linguistica Petropolitana, Transactions of the Institute for Linguistic Studies, Russian Academy of Sciences, St. Petersburg, Vol. VIII, part 3, St. Petersburg: Nauka, 2012, pp. 602-684). 
The dance of the darvishes

KarabalaKH ${ }^{95}$

KarabalaKH

DZan-blaN

DZan-blaN

Dublakh-dublakh ${ }^{96}$

He called out again and again from the darkness of the East

Father mine ${ }^{*}$ good

From there you-came

(77)

KarabalaKH

KarabalaKH

DZan-blaN

DZan-blaN

\footnotetext{
${ }^{94}$ Arm. srēš, "asphodel" (see Armenak Bedevian, Polyglottic Dictionary of Plant Names, Cairo, 1936, p. 89 no. 529; Ł. Ališan, Haybusak ("Armenian Herbal"), Venice, 1895, p. 499, no. 2373-2374; and Karapet Gabikean, Hay busašxarh ("The Armenian Plant World"), p. 183, no. 1360), is a loan from Persian serēš, with characteristic assimilation of initial $s$ to the following $\check{s}$, cf. Arm. šrawšak, a loan from Iranian *sraušaka-, "an instrument of discipline": see J.R. Russell, "Armenian šrawšak," Annual of Armenian Linguistics 17, 1996, p. 69. Šrēš hill, near Ë)̆miacin, was excavated in 1913 by Eruand Lalayean and yielded artifacts going back to the bronze age (see K. Melik'-P'ašayan and L.A. Nazinyan, intro. to Ervand Lalayan, Erker ("Works"), I, Erevan: Academy of Sciences of the Armenian SSR, 1983, p. 27). The place is mentioned in an ancient oral epic passage cited by Movsēs Xorenac'i, II.65: ... zormē yaraspelsn asen: Hatuac gnac'eal Vardgēs manukn i Tuhac' gawariēn, zK'asał getov, ekeal nstaw zŠrēš blrov, zArtimēd k'ałak'aw, zK'asał getov, krel kop'el zdurnn Eruanday ark'ayi "They say about him in the legends: The young boy Vardgēs took off and went from the province of Tuhk', along the river K'asał, came and settled around Šrēš hill, around the city of Artimēd, along the river K'asał, to cut and hew the court of Eruand [Orontes], the king." We have seen that Kara Darviš, a champion of native Armenian antiquity and folk culture as the sources of fresh creativity, took the title of the cycle from epic recorded by the same historian; and here he would have liked the princely name Vardgēs, "Rose-tresses" and the alliterative pair of verbs krel kop'el "cut and hew".

95 Tk. kara "black" is part of the poet's nom de plume; Tk. balak or malak is a buffalo calf. But he probably just liked the sound.

${ }_{96}$ Kara Darviš wrote that the word is not found in dictionaries, but anybody from Urartu in the remote past to Mongolia in the remote East would sense it had a meaning. Turkish dóbra dóbra means "say it country simple" and colloquial Armenian tpgha tpghna means "it fits like a glove". So dublakh hovers just past the edge of definition, wavers at the corner of the eye, vanishing around the corner, just as the Russian Futurist poet Velimir Khlebnikov's zaum', transrational language, ought to do.
} 


\section{Dublakh-dublakh}

From Asphodel Hill

From roundness of Kōnd ${ }^{97}$

Light will come

The sun will dawn

KarabalaKH

KarabalaKH

DZan-blaN

DZan-blaN

DUBLAKH-DUBLAKH

5. In Letters from 74 rue Taitbout (New York: World, 1969), William Saroyan (19081981) remembers the dead and addresses them. Many are eccentrics, men whose particular character or genius set them apart, left them alone, and sometimes led to a tragic death. There was Professor Kalfayan (p. 49 f.), the composer who had lived in Paris, who dressed like a dandy, and was adrift and insane in Saroyan's sleepy home town: Fresno, CA was the land of opportunity for hardworking Armenian farmers but it was not then a center of high culture. Or there was Doctor Anoushavan Chomp (p. 151 f.), the publisher of Armenian weeklies in Sofia, Bucharest, Cairo, and Paris, also a flamboyant dresser: nobody in Fresno's cafés bought his satirical paper C'axawel, "The Broom", and he vanished. In 1935, Saroyan had visited the Soviet Union with a delegation of American writers. There he met the poet Charents, who had experimented with every avant-garde movement that had swept through the dying Russian Empire and the young Soviet Union, a consummate scholar and editor and one-time friend of Kara Darviš, who injected himself with morphine, who got drunk, who had been confined in a mental hospital, who had written lyric, symbolist, bardic, revolutionary, and homoerotic poems. Charents was already in official disfavor and was gradually being ostracized from Soviet Armenian literary and civil life: the KGB arrested him during the great purge of 1937. He died late in November of that year: according to one account, he smashed his head against the wall of his cell during withdrawal from drug addiction. Others assert that he was murdered. His body was dumped in an unmarked mass grave near Erevan and has not been found. ${ }^{98}$ If the life and work of Kara Darviš marked the beginning

${ }^{97}$ An old district in Erevan, the present-day Armenian capital. Its name sounds like gund, "ball"hence its roundness!

${ }^{98}$ On Charents, see J.R. Russell, The Armenian Counterculture That Never Was: Reflections on Eghishe Charents," Journal of the Society for Armenian Studies 9, 1996-97 (1999), pp. 17-35; "Charents the Prophet," Journal of the Society for Armenian Studies 11, 2000; "From an Archive of Unpublished Poems of Yeghishe Ch'arents'," in Armenian and Iranian Studies, Armenian Heritage 
of a new kind of literature and life- a counterculture- in Russian Armenia, then the death of Charents was the end. At their meeting, Charents advised Saroyan when dealing with the authorities, the custodians of propriety and convention, and the rest of them, to say yes and then spit in their eye. Saroyan wrote from his Paris apartment to the dead poet (p. 122):

“Why didn't you say yes? I'll tell you why, Charentz. Because you are more than an Armenian, more even than only another member of the human race. You are a poet, so shocked by the treachery of all men seeking to save their skins at any cost that only with the help of cocaine could you stay among them and pretend to be one of them.

God love them, as every poet is obliged to say, not with contempt but with charity. They all did, they are all doing, only what you advised me to do, which I have never done, which you never did."

6. Osip Mandelstam's translation of Kara Darviš, "Dance on the Mountain”, with translation of the Russian by J.R. Russell:

АКОП КАРА-ДЕРВИШ

ПЛЯСКА НА ГОРАХ

Ночной хоровод

Посвящ<ается> Гр<игорию> Робакидзе

Не плач, не рыданье, не воплениц крик -

Подари мне веселье и пиршества звон.

Позабыть бы удары и смертный стон,

Катафалков пух и умершей лик,

Пустить по миру тяжелый дым,

Развеять горечь дымных туч,

И кто любим, и кто не любим,

И кто повержен, и кто могуч,

Побежденный, победитель - всё прах и дым,

Да пройдут они здесь, - мое сердце там,

Забыть, забыть - уйти далеко

К шарообразным легким мирам,

По новым звездам взвиться легко.

Press and Harvard Armenian Texts and Studies 9, Cambridge, MA, 2004; and, pp. 1365-1432; and "The Book of the Way (Girk' chanaparhi) of Yeghishe Charents: An Illuminated Apocalyptic Gospel for Soviet Armenia," Armenian Studies Program Occasional Paper Series, University of California, Berkeley, Stephan Astourian, general ed., Spring 2012, 37 pp. +31 pls. 
И только с тобой, только с тобой,

Повелительница моей души, Атом крови моей огневой.

Пойте мне песни, хоровод, пляши,

Тризну на грудах костей соверши.

Пусть бесы топчут и воют глухо -

Я слышу богов чародейный бег,

На вершинах гор рождение духа:

Ночь разрезает человек.

Жизнь вернулась, гроба раскололись,

И славы былой поют руины.

К нагорной крепи взмыл мощный голос:

Всё забыть и ринуться в звездные пучины!

Через трущобы, туманной повитые пряжей, С посвистом адским уйдем на высокие кряжи.

Всё позабудем, забудем, забудем.

Akop Kara Dervish

Dance on the Mountains

(Nocturnal Choral Round)

Dedicated to Grigorii Robakidze

Neither crying nor sobbing nor cries of professional wailers-

Let me be merry 'midst the ringing of feasts.

Forget the blows and dying moan,

The coffins' trim, the dead girl's face.

Scatter the heavy smoke through the world, Blow away the heavy clouds' grief,

And he who is loved, and he who is not,

And he who is conquered, and he who wields power,

The defeated, the victor, are all smoke and dust,

And here they will pass, but there is my heart.

To forget, forget, and go far away

To the spherical delicate worlds

And lightly soar past the new stars.

And only with you, only with you,

Mistress of my soul,

Atom of my fiery blood.

Sing songs to me, 0 chorus, and dance

Your rite on the piles of bones.

Let demons stomp and hollowly howl;

I hear the spellbinding onrush of the gods,

The birth of the spirit on the mountaintops:

Man cuts to shreds the night. 
Life has returned, the coffins crack and break, And the ruins chant their elder fame.

To the mountain eyries the strong voice ascended:

Forget all, and plunge into the gulfs of the stars!

Past these hovels, spun in a web of fog,

With hellish ululation to the high crags away

We will go and forget it all, forget, forget.

7. Kostan Zarean, Nawa leran vray ("The Ship on the Mountain"), Boston: Hayrenik', 1945, a part of Chapter 9 (pp. 140-152).

Herian had known Tiflis, the viceregal capital of the Caucasus, in those good days when after returning from a distant journey he and a few mates would come to spend their extra cash and have a good time while the ship was being loaded. Those times were so far away now...

He recalled well those nights he whiled away till dawn in rooms overhanging the Kura river, in wine shops below street level dense with the aroma of shashlik and wine, where in the semi-dark life crept up to the top of the thermometer, its tongue ringing bitter and tinny, and songs rang out in alternating happy and philosophically melancholy tones. The wine flowed and young girls danced, their shapely arms floating in the air, the fire of their great, dark eyes sharing their ardor with his heart.

In those days, Tiflis was the rendezvous of all the peoples of the Caucasus, living on permanent vacation. It was gay, official, carefree; mascaraed, dolled up, light.

The palace rearing high over the broad avenue of the viceroy, motley crowds of soldiers, military parades with their stirring music, splendid, captivating women and the idle populace strolling up and down from morning till late at night, without purpose or care. The Tiflis of lōk'ō fish, Kakhetian wine, and łōłinał. ${ }^{99}$

The most beautiful quarter of the city, called Sololak, which Armenians had built, teemed with horses of noble breeds harnessed to magnificent carriages in which magnificent women with great, swooning eyes would glace about with lightning-stricken looks, and then, after their reveries had wafted over the heads of the passers by, would swiftly roll on.

\footnotetext{
${ }^{99}$ Michael Grossman informs me that Georgian gozinaki is a confection of grape syrup hardened around string of walnuts to resemble a sausage; it is also popular in Armenia, where I have heard it called anuš sujux, lit. "sweet sausage", or ročik. The element goz- would be from Iranian for walnut, cf. the loans Arm. ankoyz and Heb. egōz. The loko is a catfish.
} 
Life rolled on, to the rhythm of the airs of soundless, trilling flutes. Abundant, voluptuous. The sweet shops, teeming with customers, displayed cakes and confections of impossible dimensions. In front of the shops, on the sidewalks, were heaped little hills of cloth and velvet. Groups of women gathered around them and with delicate, sensitive fingers palpated the silks and lazily examined the multicolored fabrics. The rustle of crumpled cloth, merging with the sweet aromas pouring in from every direction, resembled a tipsy breeze stealing over a rose garden. And here, swathed in a tent of particolored silks, her dress shivering with gold coins worked into its hem, went a Turkish lady. You would thing a hive of bees was passing. Or here, a stately and supple Circassian maiden ${ }^{100}$ with the eyes of a gazelle and the gait of an ibex; or a Persian girl sashaying along, her little head nodding, round and musical.

To reach the lower quarter of the town one had to pass through narrow, twisting lanes. Down below was the square the locals called the Mèydan, ${ }^{101}$ which unfolded before your eyes like a Persian miniature sketched by a naïve hand. Camels, lazily seated, thick lipped, heads held high, as though they were grazing on the sun. Goats with bells tinkling, dragging along dried branches by their tips. Eastern types seated with their legs folded beneath them, with dreaming eyes and dazed motions, smoking long pipes.

The acrid odor of tar, raisins, heaps of straw. Camel dung. Wretched, indifferent dogs. Hens pecking under the camels' noses, and beggars with ruined eyes and trembling hands. Asia.

On the surface it might be Europe - a Europe reflected in funhouse mirrors. Erevan Square, with its red-painted city hall. The main thoroughfare of the city, the pride of the country: Golovinsky Prospect. ${ }^{102}$ On this avenue, all the peoples of the

\footnotetext{
100 These picturesque women of the East have not only a reality in Armenian life, but a contextuality in literature. Petros Durean (Bedros Tourian) (1851-1872), the youth who in his brief life singlehandedly invented modern Western Armenian lyric poetry, wrote two poems, startling for the time in their artless, laconic literalness, about a Turkish woman and an Armenian woman he exchanged gazes with in Constantinople (see J.R. Russell, Bosphorus Nights: The Complete Lyric Poems of Bedros Tourian, Armenian Heritage Press and Harvard Armenian Texts and Studies 10, Cambridge, MA, 2005). A Circassian maiden dances in the bewitching palace of Dream before the Oriental potentate and narrator of Daniel Varuzhan's poem Het'anosakan ("The Heathen Poem"), in the cycle Het'anos erger ("Heathen Songs"): at the end of the poem he takes her in his arms and consummates his passion for her. But perhaps, given the setting, the spasm is only imagined. Like most of Varuzhan's verse, the poem is as extravagant in its rich vocabulary as it is in its imagery and theme. There is little doubt it inspired in part both the subject and the words of the poem Kaycer ("Sparks") by Misak' Mecarenc' (Medzarents)(1886-1908), whose great lyric gift and brief life make him the successor to Tourian. In the latter, the poet imagines that he watches the sensuous undulations of an Oriental dancing girl through the night and begs for the vision to linger a bit more, as dawn is breaking. Kara Darviš loved and venerated Varuzhan; and Zarian, too, knew the work of the contemporary Western Armenian poets.

${ }^{101}$ Persian and Arabic maydān, used, famously, also of the main square of Kiev in the Ukraine.

102 Now Rustaveli, after the national poet of Georgia.
} 
Caucasus, their tribes and clans, in their Sunday best, rubbed shoulders with each other. They came on holiday, for fun and adventure, and to show off.

Tiflis made its living off the hardworking, productive provinces. They purchased at a high price its carefree style, its dancing, wines, girls. In their dull provincial towns they talked of it in superlatives, salivating, voices rising in lilting tones of praise.

In reality Tiflis was a modest half-European, half-Asiatic city. Climbing rows of flat roofs clung to unimpressive hills that the locals, with their tendency to exaggeration, called mountains. A few decent streets. The Kura, a muddy river dragging its lazy way between sheer banks. A handful of bridges adorned with tasteless monuments to the Russian generals who had conquered the country. And at the center, where the veins of the city swelled, a handful of great buildings erected in pompous, various, undefinable styles. Here and there, the musical contours of Armenian churches gave profundity and nobility to the mixture.

Herian had arrived in town the day before in order to present some applications to the Georgian authorities and put an end to the excess problems in transporting his ship that had arisen thanks to the caprices of petty officials. ${ }^{103} \mathrm{He}$ was already seeing everything with different eyes.

Could this be Tiflis? Tired, preoccupied, uneasy, he walked through the deserted streets waiting for the offices of the government ministries to open. It was already past nine in the morning, but the city was not yet awake. Nothing moved. The shops and cafés were shut. Skinny nags harnessed to carriages on empty street corners stamped their hooves and the skin under their bellies shivered. Policemen pounded their beats, feeling the chill. It was cold. "You'd think," Herian mused, "it was the morning after a night-long costume ball." He felt sorry he had come: it would have been better to come to some sort of agreement with the local authorities. The hardest part was already over: his ship was loaded onto freight wagons and would have already been en route, had not some wicked men begun to concoct problems. Everybody wanted a bribe, and he had distributed all the funds he had, sold whatever he owned, and given them all that, too. No, the more he gave, the more they wanted.

The life of the city started up in a strange way. Numerous soldiers and policemen poured out of the city hall, separated into squads, and took charge of the corners of the major arteries. Herian stood still and gazed in astonishment. He had witnessed the same spectacle the day before, at the station. Tight knots of policemen had taken up positions at all the exits. They requested passports, interrogated, and searched people - that is, the Russians and Armenians. "How everything is forgotten," Herian

${ }^{103}$ Herian, an Armenian sea captain from Batum(i), is the hero of the novel: he wants to transport a ship by rail to Armenia from the Black Sea port. The cover of the novel, reproduced here, illustrates the scene. 
thought to himself. "When a storm overwhelms one's life, the memory of whole peoples is darkened. Black currents, like a hurricane, sweep away their very will, their ability to consider and to choose. The threatening breakers of the stormy sea toss away small and unimportant men. So-called leaders ${ }^{104}$ are created. All the values people fought for and swore by for years are forgotten, and they resort to the same means of brute force under whose yoke they were only lately oppressed. The talk of communism, equality, and justice, but scratch them and out pops the desiccated, jealous chauvinist. Out pops the governor ${ }^{105}$ of some backward Turkish province, the constabulary, the secret police, searches, arrests, prison, exile. Is this Tiflis?"

Here are people, at last. A few sleepy, unhurried shopkeepers open their doors for business. A patch of sky clears. It opens and sparkles on a few windows, then hides immediately and retreats back behind the clouds. It's gray and cloudy.

Where was that "Cup of Tea"106 where he used to meet his acquaintances? He kept walking, inquired, found it. The Cup of Tea was open. He stopped at its front door and stared in amazement: a detachment of the police had surrounded the passers by and was searching them. A neatly dressed, bespectacled, elderly man protested angrily. One of the cops, with a pinched muzzle and long arms, went up to him, cursed him loudly, and smacked him in the face. The aged gentleman's eyeglasses shattered, his top hat flew off, and blood trickled down his blanched face. Herian was furious. He flushed and ground his teeth. They had seized the old man contemptuously and were dragging him off.

A gentleman standing next to Herian was looking on with disgust. "It's barbarism," he said. "I don't understand what they want of those people." Herian replied, bemused. "What should they want? They're just looking for an excuse to expropriate their homes and property. They deport them to the provinces as enemies and take advantage of their absence to rob them of everything. They call this the nationalization of the country..."

Herian went inside. A lovely, clean café. Young girls and married ladies of good families worked there for a pittance. There were few customers, but even before they brought the tea and pastries he had ordered, the café filled. It was as though everybody had made appointments with each other for a specified hour. He looked on with interest, quickly gathering that most of the patrons were intellectuals and artists who had fled Russia. It was plain from their faces and movements. Sallow, thin faces, crazed and disshevelled hair, hoarse voices and the strangest outfits imaginable.

\footnotetext{
104 The Armenian word is łekavar, lit. "helmsman": this is the title Charents was vainly to bestow upon Stalin in late and fevered paeans beseeching the tyrant to spare him.

105 Turkish kaimakam.

106 Rus. Chashka chayu, a Futurist haunt in Tiflis frequented by Kara Darviš.
} 
There characters, at once comical and pitiful, were talking and arguing nonstop. They all knew each other- only he was by himself, lonely, sad, depressed. The scene at the doorway still weighed on his mind. "Could I have another cup of tea, please, Miss?" "Of course." The waitress had a voice that was sweet and resonant, rising from her bosom. Herian liked it, and felt a little calmer.

It was a pleasant environment; it seemed more a salon for a reception than a coffee house. The intellectuals there had passed through fire, been crushed, exiled, yet they labored to preserve the outward proprieties of life, those exaggerated forms of civility, that hand-kissing of ladies, the delicate sweet nothings that had been typical of pre-Revolutionary high society. He recalled the perfect manners of the French aristocrats sitting in the carts taking them to the guillotine: "If you please, Marquise, may I kiss your hand?" "Ah. My dear Count, allow me to remove my glove..." These waitresses were the same: you would think they were receiving specially invited guests at home. They drifted from one end of the room to the other, shedding smiles and sweet aromas, displaying the rustling silks of the dresses, and their bared, trembling bosoms, and their well cared for white hands.

He automatically looked down at his own hands, and hid them. But at once he withdrew them again, and laid them down on the table. Why should he feel ashamed? They were the hands of a worker. For the past few weeks these hands, these strong and sturdy hands, had been cleaning and oiling and shining the ship's engines, painting the bridge, scrubbing everything to a state of perfection. No, no reason for him to feel the least shame.

"Hey, what are you pounding your fists on the table for? Spoiling for a fight, eh?" It was Peronian. "My good fellow, you look as if you were about to attack these poor, fragile girls. Yes, all right, all right, don't start with the explanations- but here, meet my friends. Hayk Shushan, professional painter; Kara, the Futurist poet; ${ }^{107}$ Sultanian, the literary scholar. In a word, you behold all the Muses." "Very pleased to meet you. Very pleased. Hey, you bastard, I wasn't expecting to see you here. Please have a seat, gentlemen. Please sit down." "My friends need no introduction to you. We've talked... The Admiral of Lake Sevan ${ }^{108}$... You're a famous man." "How could it be otherwise," interjected Kara. "We've heard a lot of good things about you, your futuristic spirit, your plan, so daring in the present circumstances..." "Good, good, don't praise him too much," Peronian said, cutting him short. "Don't flatter him. He's a modest man, any more and he'll jump up and run away... Tell me this. What brings you here? We were expecting you in Erevan." "It's a long story. You can imagine the matters I'm dealing with." "Such as?" "I've just run into a lot of difficulties,. That's all. You know, I took my ship and even loaded it onto the train." "They were talking about it in Erevan." "In Erevan?" Herian was startled. "How did they find out?" "They find out about everything. And, well..." "Well, the railway

107 This is, of course, Kara Darviš, though the name is a single phrase, not a name and surname. 108 The lake in Armenia where Herian planned to set sail his ship transported by rail from the Black Sea. 
authorities began to put all kinds of obstacles in my way. They are doing everything they can to prevent the ship from departing. That's what I've come about. I plan to make some representations. But I'm already discouraged." He related everything he had seen in front of the café. "I want nothing to do with these people." Everybody fell silent.

"The frightful thing is," said Hayk Shushan with gloomy emphasis, "The frightful thing is the way people are trading in the diadems of their own thoughts so easily. Everything that only yesterday was the soul-illuminating ideal of all is now darkness and void. It's a seismic shock, a social convulsion, a catastrophe, and it's rolling everything down with it into an abyss of barbarity. Man is reverting to his atavistic instincts and becoming a wolf." "Which just proves," interjected Kara, ever prepared to contradict, "that those old values you're talking about do not correspond to the demands of real life." "Everything can be justified that way." "I'm not justifying it. But neither do I fear the changes taking place. Life presents ever-new demands to us as it changes, and we have to be in a position to respond to those demands. To be capable of change, to be able to fashion and forge new weapons- that's what!" "But my dear fellow, you are speaking about something else entirely..." Hayk Shushan stared from behind his glasses at Kara with a mocking smile.

He couldn't stand Kara. Who was he? The semblance of semblance. Something calling itself a literary movement had been born in Europe that was apparently the product of local conditions. Russian artists, who are great slavish imitators, had picked up the outer forms of this movement, exaggerated those, sewed a harlequin costume, and draped it over their shoulders to conceal their spiritual nakedness and unquiet madness... They daubed the tips of their noses, put on necklaces of carrots, and pinned medals made of cabbage leaves to their breasts. They surprised the bourgeoisie and charmed hysterical young girls. Kara swore by their name. He wore long, colorful tunics, an Afghan headdress, and high boots, and considered himself an apostle heralding a new life. But then, apostles are always slightly ridiculous.

"You're talking about something completely different," repeated Shushan, becoming serious. "What we are seeing and criticizing today is nothing new, just contortions of old masks... scarecrows sticking out of the depths of history." "You forget that we are in the midst of a storm. When the earth is shaken, people lose their heads. They run just where they shouldn't go. They do things that would appear ludicrous in normal times." "Well, that's doubtless true..."

The room kept filling with a throng of newcomers who squeezed in around the already crowded tables, clustering together in big groups and blocking the passages. Smoke. Noise. Herian observed attentively. "A remarkable spectacle," he said. "It seems as though danger has swept over the heads of these people. Frenzied looks, twisted mouths..."

"Russia is passing through a titanic sieve. The heavier grains remain; the rest is scattered to the winds..." "Refugees..." 
"If a man thinks well," exclaimed Sultanian, "flight is base. A man ought never to abandon his fatherland, even if his life is in danger. An émigré, in the final analysis, is but half a man." "They've fled hunger, repression, deprivation." "Precisely. They fear deprivation. But see, they are already like dead leaves driven by the wind. There is one thing I don't understand. If millions of people are suffering, why should artists flee that suffering?"

"I agree completely," said Kara. "Completely. One must have the courage to accept reality as it comes and then transform that reality into art, however savage it may be. Song can offer a foundation to everything." "That is irrefutable," Herian agreed. "One must remain, strive, survive. We are all responsible for the events taking place, and we have to have the courage to bear their cosequences."

"The spirit is the main thing. Every man must cling to his spiritual center. Events are what surround us; they are not our inner selves. They arrive, the storm breaks, and then they pass - and, in the end, they are subject to the spirit, if the latter is great and radiant. We, the Armenians., have known this for centuries..."

"Those refugees present a very interesting spectacle," said Hayk Shushan again after a brief silence. "I've been observing them ever since they came. This crowd is composed not only of artists and poets. There is every kind of element among them. When they came, they were a pitiful sight: poor, thin, emaciated... But they lost no time. A lot of them, characters with calculating eyes and low, intent brows, took stock of local conditions right away, sniffed out their surroundings and got to work. Lots of shops opened. They bought and sold everything. They changed money and amassed gold, silver, and precious stones. Many ladies appeared as well, soon enough. With sonorous, aristocratic names. Baronesses, countesses, princesses. With great airs, with loving smiles. They assumed the patronage of the artists and writers..." "According to tradition..." "Yes. On that pretext, they opened nightclubs where they welcomed you in the noblest form, with compliments befitting the occasion, with self-deprecating smiles; where you met famous names you'd read about once upon a time in the Petersburg or Moscow papers. They would proffer to you the inevitable cup of tea. One of the ladies would sing sotto voce. They served sweets and cakes. They conversed and disputed about art." "Well, so?... It wasn't a bad thing."

"No. It was very nice. The bad part was that afterwards, they would invite you into the room with the roulette wheel-all for a charitable aim. Naturally you were abashed and accepted the proposal. They relieved you of your last kopek, and, with your face frozen, guilty for not having more money, you got outside somehow and fled."

"So that was the deal." "Now Tiflis lives that life. Nightclubs, beautiful Russian princesses, famous artists. It's surprising how much of the higher strata of the nobility have discovered a profit motive in art... They invite you to a soirée where 
some famous poet is to read his latest work. A full house. A little stage at the very end of the hall. Enthusiastic applause. The poet comes on stage. Wearing a long, outlandish robe woven of Bukharan silk, the tip of his nose painted, his face bedaubed with antimony like a clown, he starts to declaim in the manner of a thirdrate actor, in feeble and faraway voice, unique and incomprehensible words."109

"Fortunately," said Peronian, "In that respect our country does not attract anybody. We are poor, and have at least the honor to live alone with our accursed questions and our tragedies. We lead a dangerous life: external foes, malaria, typhus, and hunger within, and our exiles are no princesses... That is how I prefer it. One day we will forge new and beautiful things from our misfortunes. Our own beauty, deep and great, of the kind all things born of suffering are..."

They were silent. Everyone felt himself oppressed by a great burden. They returned in their minds to Armenia. They said not a word.

"But haven't you noticed how pretty that tall young lady is, the one who served us our tea?" asked Shushan, as though waking from a dream. "Really." "She's from a very good family. Well bred, educated, with refined tastes." "She caught my attention the minute I came in," said Herian animatedly. "She has real classical lines, like a Greek statue." "But, well, never mind, better I should not puncture your illusion." "Our illusion? What do you mean? Morality?" "No, no, that's not what I meant. All of you, stop looking her way or she'll realize we're talking about her." "All right, tell us what it's all about." "Look, she's got something thrown over her left shoulder to cover her arm." "Yes indeed." "The reason is that one arm is a lot shorter than the other." "Really? What a pity!" "Brother, what were you about to say?"

"You were the ones who insisted. And besides, I wanted to say that every instance of happiness conceals a wound we can't see. We talk about our country, about our misfortune... I thought, you can't create anything out of mutilated beauty, but one can make a life that has been mutilated, shattered, full of suffering into the noblest treasure..."

"Depending," interrupted Sultanian. "It depends... long drawn out physical torment makes one dull and insensitive. Suffering is beautiful when it nurtures creative forces, flights of the spirit, a plenitude of being, all of which seek the means to express themselves. Dante sticks out, right at the peak of his dark age. He is the echo of one of the most savage epochs of Italy's history. An echo, and a judge."

"Yes, because his particular, powerful, spiritual unity was indivisibly joined to his racial unity. He was a wrathful judge, in the name of the supreme traditions of his race," added Shushan.

${ }^{109}$ Ezaki ew anhaskanali barer: a reference to the zaum' ("transrational") language of Futurist poetry; $c f$. the recitation at the end of this excerpt. 
Kara leapt up from his chair in protest. "Tradition! Tradition! For the love of the gods, let's leave those antiquated, worn out ideas behind, and put a stop to this feeble old talk of yours. Look around us. Life's rushing headlong, speeding like a bullet bursting from a gun, and you make speeches about tradition... Brother, it's high time to understand that if we're stuck in this predicament today, the reason is that we were educated by a bunch of stupid parish priests, and by some celibate ones no less stupid. Always the same talk: our glorious past, our virtues, our Christianity, Sahak-Mesrop, 110 the invention of our script, the lamp of the Illuminator, ${ }^{111}$ the wisdom of our forefathers, that fig tree growing in our native village, the yogurt grandma used to make... And the results? The results are plain to see: our inability to comprehend the awful events that are crushing us; this century, that has taken up arms against us; history, that is forging unknown shapes for us. Why should I hide it? Our writers are more responsible for this incomprehension than anybody else..."

Sultanian responded, “That's it, you're all heated up again, Kara. Of course you're partly right to blame our educators. We're all in agreement there, I think. To talk about tradition the way those gentlemen do is a sign of mental torpor and retardation, of mediocrity, a hackneyed way of thinking, and so on..." "That's just the way it is..." "They are small men, not always sincere; and they attempt to cover up their mediocrity behind empty formulas. Doubtless, those ideas played a necessary role once upon a time, creating things whose memory is lost- but they don't mean a thing anymore and I find no echo of them in my own thoughts... It's as plain as day." "Bravo!" "That's how it is. But let's not forget another important factor. Progress in the lives of nations, in their history and thought, is nothing if not a renewed return to the native essence of a race, to that pristine and limpid source from which its cardinal virtues sprang, on which its will to exist is founded, those pure and primordial energies that have nurtured and justified its existence. From that point of view, every genuine revolution is a going back, not to something superficially labeled as tradition, but to that which shaped the spiritual nature of the race, the root cause of its birth."

"Primordial nakedness." "I don't know whether I can explain what I mean... The real revolution is accomplished when a race rediscovers its own eyes, shining, illuminated by innocence - the eyes that can discern what is indispensable in the light of eternity and then fashion that necessary thing into human, purely human, values. Reality exists in epochs. It is a juxtaposition of the past and the present. It is that supreme unity of life that we are cultivating anew, the way a sower's grand, simple gesture by its power cultivates a furrowed field."

110 Catholicos Sahak and St. Mesrop Maštoc' invented the Armenian alphabet early in the fifth century.

111 Although he uses for lamp the word črag, Kara Darviš probably has in mind the patriotic poem Lusaworč'i kant'eła "The lamp of the Illuminator" by Yovhannēs T'umanean. St. Gregory the Illuminator converted the Armenians to Christianity early in the fourth century AD (the date of 301 has gained official, if not scholarly, acceptance); and Armenia has always regarded itself therefore as the first Christian nation. 
This talk reminded Herian of Mark, whom he had met in Armenia. If he were here now, he thought, he'd say his piece, too. "I know. In Armenia..." But he was unable to finish.

For everyone had turned their heads to a nearby table. A squat young man with eyes bulging like a frog's and arms flailing like a windmill, was declaiming something at the top of his lungs in an unknown language. His mouth was twisted strangely, and what emerged sounded like the meowing of a cat. He hissed and roared like the wind, then chirped like some songbird in an unknown tropical forest, clucked like a hen, cackled, growled. He was most animated. He ckutched his hands to his breast, rolled his eyes, his body contorted, his lips distended like rubber, expressing some inner agitation or grief in their whistle.

"What's all that about?" exclaimed Herian in astonishment. "Is he sick, or what?"

"No," replied Kara gravely, "He's just a poet who belongs to the literary group called 40 Degrees... That fellow, a friend of mine, is the ingenious inventor of an international phonetic language. He is reciting a great poem entitled 'A mother's lament over the grave of her child'. It is a beautiful and impressive lyric. One has to say that it is a genuine revolution in its manner of form and expression."

"Just the thing," cried Shushan, turning to Sultanian, "Precisely the return you were just preaching." "To the age of the wild beasts!" Everybody laughed. "It just shows," replied Sultanian evenly, "That one can make foolishness of every truth... I was talking about the primordial spirit of a race, the spiritual flight of the epoch of its birth, not about crawling around on all fours..."

"Let's not get started on the same argument again," interrupted Peronian. "Time is passing. We have a thousand and one things to do, and anyhow, we need to get something to eat, right? Come on, let's go..."

\section{Excursus on visual language.}

The "transrational" (Rus. zaum') language of the Futurists represented an attempt to break or transcend the convention whereby a word is just a signifier and relates in a single and linear way to the signified (the word "chair" points straight to a chair and to nothing else). It proposed an array of possible associations- new meanings for a word and new realities in the field of perception. The way it did so was most often by emphasizing the sound of a word rather than its assigned meaning. In some cases the intention was to dispense with any semantic featureto produce a text of unfamiliar, archaic words, from magical texts or the like; or words of the kind people in religious ecstatic states use when speaking in tongues 
(glossolalia); or the onomatopoetry of the sounds of the world around us, whether natural or mechanical; or nonsense words. Rimbaud had called for a derangement of the senses, and one way to achieve this on the level of language was to use sound patterns that were felt to be unusual and exotic with respect to the language of the writer. In the case of Armenian, one might find frequent use of the rare sounds $f$ (cf. the crypto-Persianate words invented by Kara Darviš with the syllable far) and $\bar{o}$. One might use of rhyming, singsong patterns with a high proportion of open vowels, in the manner of children's chants. At other times a new word, by virtue of its formal, phonetic relationship to known words in the reader's language, might call up a few or many diverse subliminal associations. These associations were of necessity to a great extent arbitrary, dependent upon the individual reader's perception - his own stock of imaginative associations, aesthetic sensibilities, aural experiences, life background, and so on. It was left to the reader to decide what the author meant, if indeed the latter intended any particular, definable meaning to start with.

Kara Darviš muses in his manifesto Arewelk'a ibrew ałbiwr nor gełaruesti ew stełcagorcut'ean (Hin goynera nor p'ayli tak) ("The East as a source of new fine art and creativity - Old colors with a new shine"), translated here, that although his invented word dublakh does not appear in any dictionary, every Armenian, Tatar, and Mongol reading it will intuitively feel it has a meaning. So the author made up his text and assigned its sounds, perhaps with a personal and unexpressed sense of what it all meant to him. But once the text left the presses, that text became entirely dependent for its semantics, though not its sound, upon each individual reader. In that sense, the reader really did become the author. He was no longer the passive recipient of a message, whether a careful reader or a hasty one. He had to make up the message himself. I stress this because the author transferred thereby to his reader the quality of agency, the responsibility to act.

But there is something else a visual text can do that auditory conventional language and zaum' cannot: it can alter its shape, pattern, size, and direction. All spoken language is linear and temporal: a speech act, no matter how musical in pitch or varied in loudness it may be, has a beginning and an end, and takes time. So, does a substantial 19th-century novel, in one standard typeface with conventional punctuation, the lines marching from left to right and descending the page, moving to the next, and so on till after many a summer dies the reader of War and Peace or Bleak House. A Futurist text does not do this: the sizes and fonts of printed letters change, in defiance of the rules of orthography; and sometimes the letters do somersaults or lie down on their sides. ${ }^{112}$ They are not sequential; they are synchronous. Lines break rank; and often an illustration, whether it is a Cubist woodcut or a wallpaper pattern in the background of the page, merges with the text. In 1914-1916, Carlo Carrà and Paolo Buzzi produced centrifugal, sunburst-like texts

\footnotetext{
112 Jeffrey Schnapp in his essay in Greene, ed., Italian Futurism, op. cit., p. 156f., notes that the first writer to use intentional typographical experimentation of a sort of absurdist, proto-Futurist kind was the English writer Lawrence Sterne in his novel Tristram Shandy (1760), which the Italian Futurists esteemed.
} 
that compel the reader to turn the page around, to arrange the order of the different words and sentences as he pleases. ${ }^{113}$ You can interpret a picture but you cannot read it out loud: it imposes a silence. The important point to stress here, then, is that this is the point where the text breaks away from sound altogether, and, in a way, from time also. One might arbitrarily interpret large letters as loud sounds and small letters as fainter ones, making of the text a sort of musical score; and Russian Constructivists began in the 1920 s to experiment with alternative forms of musical notation. In the west, John Cage and other composers performed similar graphic experiments.

However purely visual elements such as a picture, a leafy pattern from folk art, an unknown graphic symbol, etc., are scarcely susceptible to such a reading. The phonetic signature of the text becomes, then, silence; or the merging of the clamor of many Futurist voices on the page with the large silence of visual composition.

The Russian and Armenian Futurists, returning to what they saw as pure and atavistic springs of sound and feeling unchained by convention, drew upon folk spells, ancient myths, and magical texts. The sound of these is clear enough; but what of their shape, their silent language? One place to start is non-alphabetic signs such as hieroglyphs. Egyptian, Mayan, and Chinese generally have three components: ideographic, phonetic, and determinative. Although the phonetic aspect is important, the observations of William S. Burroughs in his essay "Hieroglyphic Silence" are still of interest: "No matter what the spoken language may be, you can read hieroglyphs, a picture of a chair or what have you; makes no difference what you call it, right? You don't need subvocal speech to register the meaning of hieroglyphs. Learning a hieroglyphic language is excellent practice in the lost art of inner silence... What keeps you from seeing what is in front of you? Words for what is in front of you, which are not what is there." And he presents an Egyptian hieroglyphic text written in multiple directions on a page broken up by floor planlike drawings into quadrants, ${ }^{114}$ which can be read, but not sounded. Burroughs and his companion Brion Gysin experimented in their paintings with both grids and compositions with lines radiating from a center, usually in the four cardinal directions. ${ }^{115}$

William S. Burroughs was interested also in Mayan glyphs. These were sometimes written in patterns where "a centrally embedded perspectival view scans simultaneously in multiple radial directions" - a type that, as we shall see presently, is found in Armenian magical manuscripts, even though the Armenian alphabet

\footnotetext{
113 See Greene, ed., Italian Futurism, op. cit., illustrations on pp. 162-163.

114 William S. Burroughs and Brion Gysin, The Third Mind, New York: Viking, 1978: "Hieroglyphic Silence," pp. 186-187; figure on p. 188: illustrated here.

115 See Brion Gysin, Dream Machine, catalogue for an exhibition at the New Museum, Merrell: London, 2010, p. 126.
} 
script as such does not lend itself to this graphic strategy. ${ }^{116}$ Close to the end of his life, in 1944, Kandinsky started a watercolor of large, variously distributed and vaguely hieroglyphic shapes; in one corner is a "text" (successive horizontal lines of left-to-right characters) of smaller, similar shapes inspired by Rapanui rongorongo script. The latter has an artistic advantage over Egyptian if one's aim is to release the reader from verbal and phonetic patterns, since it has not been deciphered.

The title of Vasilii Kamensky's Zheleznobetonnaya poema solntse (lubok) ("Ferroconcrete poema, the Sun (woodcut)"), 1917, makes multiple statements: it is Futuristic, with the industrial, urban reference to reinforced concrete; it is a spatial map, since it is overtly related to his other ferroconcrete poem, Tiflis; it claims an old Russian folk pedigree as a lubok-woodcut; and it declares itself a poema, a verse composition of significant length and high seriousness of theme. The composition has a radiant sun with an eye at the center (called "the face of the GENIUS"), with a planet, Moon, and star around it. The Russian and zaum' text meanders around and along the lines of the drawings. The sun has four principal rays in cruciform shape that divide the text/picture into quadrants; and with the natural tendency to read Russian from left to right one starts with the large letter $Y u$, expecting it to stand for Yug, "South", with the Z, S, and V of zapad, sever, and vostok to follow; but the other "cardinal directions" are marked with vowels, $\mathrm{A}, \mathrm{O}$, and $\mathrm{E}$, forcing the reader to make vocalic sounds instead of reading consonantal abbreviations. The chief effect of this division into four implied directions, together with the circular aspect of the central figure in the poema, is to force the reader/viewer to rotate it in order fully to observe it and read it. That is, he must move the object, or move himself, or maybe both. Movement thus becomes part of the act of reading.

Two Armenian magical manuscript texts from Venice, illustrated here, are arranged in the same way as Kamensky's composition, though both are nearly a century older at the least. In both there is a central, circular portion with various incantatory texts and prayers both surrounding and radiating from it. In the first manuscript, 117 the texts are divided into quadrants, which are subdivided into triangles. In order to read the texts, one must rotate it clockwise, which is also the direction of the writing in the central circle. The texts within each quadrant, however, proceed counter-clockwise. So two opposite rotations are required, in four series - rather like the wheels of the divine throne in the chariot vision of Ezekiel! All the texts in this manuscript are in standard Classical Armenian, and the whole is evidently a nocturnal talisman: Ch. 12 of the Narek, recited as an evening prayer for protection of the home; Ch. 41 of the Narek; the credal prayer "I confess in faith" of

\footnotetext{
116 See Javier Urcid, "The written surface as a cultural code," in E.H. Boone and G. Urton, eds., Their Way of Writing: Scripts, Signs, and Pictographics in Pre-Columbian America, Washington, DC: Dumbarton Oaks, 2011, p. 115, discussion of fig. 6.3.

117 Published by Frédéric Feydit, Amulettes de l'Arménie Chrétienne, Venice: S. Lazare, 1986, MS XXIV (Venice 3064), described on p. 70. The owner was one Xaspik'an, probably a form of the AraboTurco-Persian name Xasbēg, "Noble lord", which is first attested from the mid-14th century (see H. Ačariean, Hayoc' anjnanunneri bararan "Dictionary of Armenian proper names"), repr. Beirut: Sevan, 1972, vol. 2, p. 500).
} 
St. Nersēe Šnorhali; a prayer of Yovhannēs Garnec'i against nocturnal terrors (i.e., nightmares: arhawirk' gišeroy); other prayers to ward off demons; a prayer against headaches; etc. ${ }^{118}$

In the second manuscript, an undated and uncatalogued magical compendium at $\mathrm{S}$. Lazzaro, Venice, photographed by Rachel Goshgarian, the texts radiate in scythe-like patterns, recalling the "eternity" symbol employed in Armenian Christian art. This manuscript was made, not for purely orthodox prayer, but for magic: it contains voces mysticae, pseudo-magic squares with both Arabic numbers and other symbols, and a variety of esoteric signs. Some of the latter are astrological, while others do not belong to any known writing system. The composition thereby in various ways anticipates the multiple strategies of writing to be employed by the Futurists. And one recalls here Gurdjieff's claim, noted above, to have seen the four-directional text of the mystical Imastuns!

Kara Darviš used to stand outside the Tiflis cinema with his postcard texts. It is intriguing to consider that a postcard is a text intended to move- to be sent through the mails. It is an open text, too, unlike a letter in a sealed envelope or a book between covers. And inside the building, Kara Darviš' fellow citizens of Tiflis were becoming, whether they were fully aware of it or not, readers of a wholly new kind of text, too: the moving picture. It is the modern, urban environment becoming aware of the possibilities of new technologies and dimensions, the human mind and body learning how to bring dream into consciousness, how to fly...

$* * *$

Excursus: A note on the Beat poets and the Armenians.

Jack Kerouac's novel On the Road and William S. Burroughs' Naked Lunch, together with Allen Ginsberg's poem Howl, are the primary classics of the Beatsthe social and artistic rebels of the 1950's whose revolutionary innovations were to lay the foundation for the Counterculture of the 1960's in America and maybe around the world. One of the formative events of the Beat movement was the murder in 1944 of a member of the nucleus of their group, David Kammerer, by another, Lucien Carr, in Riverside Park near the Columbia campus in upper Manhattan. ${ }^{119}$ Carr was a handsome, pale, delicate-featured boy of nineteen;

118 The Narek is the name given by Armenians to the Matean ołbergut'ean ("Book of Lamentation"), a cycle of 95 mystical prayers by St. Grigor Narekac'i, 10 th century. On Ch. 12 see J.R. Russell, "Grace from Van," Journal of the Society for Armenian Studies Vol. 7, 1997, esp. p. 42. On the credo, see J.R. Russell, "The Credal Poem Hawatov xostovanim ("I confess in faith") of St. Nerses the Graceful," in J.J. van Ginkel et al., eds., Redefining Christian Identity: Cultural Interaction in the Middle East since the Rise of Islam, Orientalia Lovanensia Analecta 134, Leuven, 2005, pp. 185-236.

119 This event is the subject of the magnificent and intensely moving film "Kill Your Darlings" (2013), directed by John Krokidas. The fictionalized story in color, with period music from the 1940s, ends contrastively with iconic still photographs in black and white of the actual Beats themselvesBurroughs in trench coat and hat, Ginsberg in Varanasi- and the poignant punk anthem “Don't Look 
Kammerer, an older gay man and childhood friend of Burroughs who had for several years been a mentor and lover of the youth. Both Burroughs and Kerouac were arrested as accessories to the crime since they had failed to turn in Carr after he told them about the murder; but they were quickly let off. Although Burroughs was gay; and Kerouac, bisexual - both thought it best to try to save their friend Carr from the hot seat by letting the murder be presented as a typical case of a young straight man defending himself against the advances of a predatory older homosexual. The Ivy League murder made headlines for a while, and the archetypal homophobic set piece was just right for a public that liked its scandals served up with a moralizing sauce. We were to live with this till the Stonewall riot of 1969, when the gays finally understood that freedom is something you have to fight for and take. It is never given. But even revolutionary gays often internalized the stereotypes and prejudices of an oppressive system. So one wonders whether Burroughs' assent to the cover story of innocent youth vs. older gay pursuer was not just a tactic but also a symptom of self-hatred: Burroughs, too, had a taste for adolescent boys that he indulged often for most of his life. The writer was to dissect the theme with the same ruthless clarity he applied to junkies and addiction: his early novel Queer, which Burroughs published only in 1986, deals with an older gay man- Burroughs' own persona- consumed by self-loathing in his humiliating desire for an indifferent, younger man. It is, in a way, the same passion play, with Burroughs as Kammerer, though there is no murder.

In the end, Carr didn't beat the rap and did some hard time, but he didn't get the chair either, and went on to a successful career as a literary editor in New York. His son Caleb Carr is a well-known novelist. Lucien and the other principal Beat characters lived to the end of the $20^{\text {th }}$ century or beyond. So even though Kerouac and Burroughs collaborated on this roman à clef about the murder, and the lives in Greenwich Village of the early Beat circle - it is their very first novel, and the title comes from an absurd-sounding phrase in a sensational radio story- publication had to wait till everybody concerned was dead. The book appeared in 2008,120 and it's a good one, written in the gritty, hard-bitten, black-and-white style of conventional wartime realism, but with lots of tasty hints of the literary transformations to come. An excellent historical and textual essay by James Grauerholz, Burroughs' life partner and literary executor, is appended to the volume. I seek here to illuminate a small but significant detail Grauerholz failed to address or explain in his indispensable afterword.

All the characters of the drama, naturally, are thinly concealed by fictional names: Lucien Carr, the killer, is called Phillip Tourian and is variously described by the authors as a Turk, or as having Greek relatives, or as hailing from Istanbul. The

Back Into The Sun" by Peter Doherty and The Libertines. The new song in juxtaposition to the pictures from an already distant past is an affirmation that the great chain of rebel artists and visionaries lives on.

${ }^{120}$ Jack Kerouac and William S. Burroughs, And the Hippos Were Boiled in Their Tanks, New York: Grove Press, 2008. 
character in the novel is seventeen (Carr was nineteen at the time of the murder) and is swarthy and handsome (Carr was from a well-to-do Anglo family and was blond and blue-eyed). For whatever reason, the fictional character has a very different background and appearance than the historical Carr, so the choice had to be intentional. It is also likely the two authors knew Tourian was an Armenian surname (Turkish and Greek surnames do not end in -yan, though Iranian ones can). William Saroyan, the American Armenian writer cited elsewhere in this study, is mentioned in passing, though without reference to his ancestry. At the time Saroyan was still widely known as a very famous American writer, of course. (No longer: in an informal recent poll, none of my students at Harvard had ever heard of or read his book My Name Is Aram.) The name Tourian is an obscure one outside the American-Armenian community.

It was, as its use in the novel suggests, not yet an obscure name to the general public in the 1940s, though. Only a decade earlier, on Sunday, $25^{\text {th }}$ December 1933, the Primate of the Armenian Church of North America, Archbishop Leon Tourian (Łewond Durean), a native of Constantinople, was murdered as he was celebrating the Divine Liturgy at the Holy Cross Church of Armenia on West $187^{\text {th }}$ Street and St. Nicholas Avenue, just three miles north of the Columbia campus. Several top officials of the New York branch of the Armenian Revolutionary Federation (Arm. Hay yełap'oxakan dašnakc'ut'iwn - Kara Darviš numbers himself among the Dashnaks in one poem) were apprehended at the scene of the crime, tried, and convicted of premeditated murder in the first degree. (All escaped the death sentence.) The crime was front-page news for weeks in the city; and the trial was one of the more sensational courtroom events of the first Great Depression. No specious moralizing was needed to spice up the story: Tourian was stabbed through his gilded vestments, in the nave of a house of God, with a long kitchen knife. He was a tall, imposing man, and his heavy metal crozier buckled as he fell upon it. There was a sickening irony to this murder by fellow Armenians: when in 1922 Mustafa Kemal Atatürk's army burnt down the port city of Smyrna (present-day Izmir) and drove its Christian majority population into the sea, literally, Bishop Tourian had been one of the survivors picked out of the water. He could scarcely have come from a more illustrious or patriotic family: just a few years before his murder his cousin Yeghishe (Ełišē) Tourian, an eminent scholar who had served as the abbot of Armash monastery, and then been elected Armenian Patriarch of Jerusalem, passed away in the Holy Land. When Yeghishe, born Mihran, was a boy, he witnessed the slow, agonizing death from consumption of his own elder brother, Bedros (Petros).

Bedros Tourian, who died at Constantinople at twenty-one, early in 1872, was an inspired, grief-stricken romantic: with his small corpus of brilliant lyric poems it is fair to say he created the standard modern literary idiom of Western Armenian. And in his use of startling images like "black milk" he both paralleled the linguistic experiments of his French contemporary, Arthur Rimbaud, whom I have cited as the progenitor of modern poetry and of Futurism; and anticipated the $20^{\text {th }}$. century German-language poet Paul Celan, whose most famous poem, "Death Fugue", uses the image of black milk to great effect in evoking the anti-life of 
imprisonment and extermination in a Nazi concentration camp. It is most unlikely the fathers of the Beat movement ever heard of Bedros or Yeghishe, but it would have been hard for them not to know about Leon Tourian. And surely the only reason for the employment of that obscure name in their very first novel would have been the recent and notorious murder of the Archbishop in New York. It is a reference that would have been immediately understood by many Americans - and more New Yorkers - in 1945. But now that nearly a lifetime has passed, only the eyebrows of Armenian readers will travel upwards. For them, the effects of the murder endure.

The circumstances of Tourian's assassination are complex. In 1917, following the Russian Revolution and the collapse of the Tsarist régime, Lenin withdrew his country from the war and the Russian army decamped from the Caucasian front. Ottoman Turkey had begun systematically to exterminate its civilian Armenian population in 1915, and refugees were fleeing with the retreating Russians from Van and elsewhere to the east. The Dashnaks established an independent republic in Transcaucasian Armenia - the part of the country that had been since 1828 under Russian control- and fought back Turkish and Azeri invading armies. But they lost power to the Communists in 1920 in a coup and were driven into exile in the Middle East and the U.S. The sacred city of Echmiadzin, seat of the Armenian Church since the fourth century, was to remain in Soviet hands thereafter, until 1991. In 1922, as was mentioned earlier, Atatürk's army destroyed Smyrna on the Aegean coast, where Tourian had served as bishop.

Arriving at his new post in America, Archbishop Tourian, either out of personal conviction or in an effort to placate the Russians and thereby protect his Church from reprisal, refused at several Armenian American community functions to allow the Dashnaks' tricolor flag - the flag of the pre-Soviet (and, now, postSoviet) republic - to be displayed, allowing only the Stars and Stripes. The party's members were incensed by this offense and branded him a traitor; and his subsequent murder split the American Armenian community down the middle. Many remained loyal to the Catholicos, or supreme patriarch, at Soviet-controlled Echmiadzin; others broke away and eventually came to associate their parishes with a rival, Dashnak-dominated Catholicossate established at Antelias, near Beirut, Lebanon. The English-language US Dashnak press in the first decade of the $21^{\text {st }}$ century ran a series of portraits of the various Armenian parishes in America: the article on Manhattan's Holy Cross Church faithfully mentioned every detail of its history except the only one of any historical importance- Tourian's murder. Though the subject still seems too delicate for the party to address with candor, Terry Phillips' book Murder at the Altar provides the a detailed, if at times speculative historical account of the Tourian case to date, albeit in semi-fictionalized form.

The resurrected proto-Beat novel turns out to be another, surprising, corrective to historical amnesia. For the very name Tourian evidently summoned such visceral imaginative force that invoking it was enough to convey the tragedy 
and horror of bloodshed and the derangement of its aftermath. And that experience of dislocation became itself a strong factor propelling both William S. Burroughs and Jack Kerouac towards their mature style, to the writing that jumpstarted the great Counterculture. The poet and scholar Peter Balakian came to Armenian activism in the wake of youthful encounters with the Beat poet Allen Ginsberg; and in The Burning Tigris he has argued that organized support for the Armenians at the time of the Genocide was the beginning of the modern movement for human rights. In that sense, the fate of the Armenians and the response of people of conscience to it was part of the political patrimony of the wider counterculture. I became aware of Armenian culture and the Armenian cause in the context of a youthful involvement with Black civil rights, the Left, opposition to the Vietnam War, and, later, gay liberation. It was the Counterculture, with its consciousness-raising and its activism - its sense-deranging and Futuristic drugs and sex and rock and roll- that despite its shortcomings liberated all of us. And in the very first writings of its very first artists we find an Armenian name whose farther echoes are replete with tragedy and horror, but also with creativity and love.

\section{List of illustrations.}

1. Sketched portrait of Kara Darviš by Vladimir Mayakovsky, 1914.

2. Tēvrišin k'eškiwra ("The Dervish's begging bowl"), Boston: Tparan Hayrenik' ("Fatherland" Press), 1930, title page.

3. Vasilii Kamensky, Zheleznobetonnaya poema - Tiflis ("Tiflis, a ferroconcrete poem").

4. Kara Darviš, Inč' ē fut'urizma ("What is Futurism?"), title page.

5. Arshin Mal Alan musical score, New York, 1924, title page.

6. Rusalki poyut ("The undines sing"), illustrated in S.E. Strizhnëva, ed., Budetlyanskii klich! Futuristicheskaya kniga ("The Call of the Futurists! The Futurist book"), Moscow: Fortuna EL, 1996, p. 79.

7. Kara Darviš, text of zaum' poems from the volume dedicated to Sofia Mel'nikova.

8. Kostan Zarian, Nava leran vray ("The Ship on the Mountain"), Boston: Tparan Hayrenik' ("Fatherland" Press), 1943, title page illustration by F. Zarian.

9. Ralle and Baudelot pre-Revolutionary Russian soap wrappers.

10. William Burroughs, "Hieroglyphic Silence", in William S. Burroughs and Brion Gysin, The Third Mind, New York: Viking, 1978, p. 188.

11. Armenian magical manuscript, from Frédéric Feydit, Amulettes de l'Arménie Chrétienne, Venice: S. Lazzaro, 1986, MS XXIV (Venice 3064).

12. Armenian magical manuscript, S. Lazzaro, Venice, uncatalogued: photo by Prof. Rachel Goshgarian, Lafayette College, PA.

13. Vasilii Kamensky, Zheleznobetonnaya poema-Solntse ("The Sun, a ferroconcrete poem"). 